\title{
Chemotherapy dose-intensification in breast cancer : is more better?
}

Citation for published version (APA):

Lalisang, R. I. (2010). Chemotherapy dose-intensification in breast cancer : is more better? [Doctoral Thesis, Maastricht University]. Datawyse / Universitaire Pers Maastricht.

https://doi.org/10.26481/dis.20100611rl

Document status and date:

Published: 01/01/2010

DOI:

10.26481/dis.20100611rl

Document Version:

Publisher's PDF, also known as Version of record

\section{Please check the document version of this publication:}

- A submitted manuscript is the version of the article upon submission and before peer-review. There can be important differences between the submitted version and the official published version of record.

People interested in the research are advised to contact the author for the final version of the publication, or visit the DOI to the publisher's website.

- The final author version and the galley proof are versions of the publication after peer review.

- The final published version features the final layout of the paper including the volume, issue and page numbers.

Link to publication

\footnotetext{
General rights rights.

- You may freely distribute the URL identifying the publication in the public portal. please follow below link for the End User Agreement:

www.umlib.nl/taverne-license

Take down policy

If you believe that this document breaches copyright please contact us at:

repository@maastrichtuniversity.nl

providing details and we will investigate your claim.
}

Copyright and moral rights for the publications made accessible in the public portal are retained by the authors and/or other copyright owners and it is a condition of accessing publications that users recognise and abide by the legal requirements associated with these

- Users may download and print one copy of any publication from the public portal for the purpose of private study or research.

- You may not further distribute the material or use it for any profit-making activity or commercial gain

If the publication is distributed under the terms of Article $25 \mathrm{fa}$ of the Dutch Copyright Act, indicated by the "Taverne" license above, 
Chemotherapy dose-intensification in breast cancer: is more better? 
(C) 2010 Roy Lalisang, Maastricht

Cover design: Fabiano Peltrera

Layout: Tiny Wouters

Production: Datawyse | Universitaire Pers Maastricht

ISBN: 978-90-5278-940-8

Financial support for the printing of this thesis was kindly provided by:

AstraZeneca BV, Roche Nederland BV, Pfizer bv, GlaxoSmithKline bv, Eli Lilly Nederland BV, Amgen BV, sanofi-aventis Netherlands BV, Novartis Oncology, Shering-Plough Nederland BV, Abbott BV, Celgene BV. 


\title{
Chemotherapy dose-intensification in breast cancer: is more better?
}

\author{
PROEFSCHRIFT
}

ter verkrijging van de graad van doctor aan de Universiteit Maastricht, op gezag van de Rector Magnificus, Prof. mr. G.P.M.F. Mols, volgens het besluit van het College van Decanen, in het openbaar te verdedigen op vrijdag 11 juni 2010 om 12.00 uur

door

Roy Iqbal Lalisang

Geboren op 1 november 1958 te Leiden

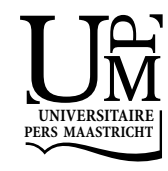


Promotores:

Prof. dr. V.C.G. Tjan-Heijnen

Prof. dr. H. C. Schouten

\section{Beoordelingscommissie:}

Prof. dr. M.F. von Meyenfeldt (voorzitter)

Prof. dr. R.F.P.M. Kruitwagen

Prof. dr. P. Lambin

Prof. dr. J.B. Vermorken, Universitair Ziekenhuis Antwerpen, België 
Voor mijn ouders, Monique, Tom, Roepie en Bibi 



\section{Contents}

Chapter $1 \quad$ Scope of this thesis 9

Chapter 2 Comparative study of dose escalation versus interval reduction to 15 obtain dose intensification of epirubicin and cyclophosphamide with G-CSF in advanced breast cancer Journal of Clinical Oncology 1997;15:1367-1376

Chapter 3 Dose dense epirubicin and paclitaxel with G-CSF: a study of decreasing intervals in metastatic breast cancer British Journal of Cancer 2000; 82:1914-1919

Chapter 4 Epirubicin and paclitaxel with G-CSF support in first line metastatic breast cancer: A randomized phase II study of dose-dense and dose-escalated chemotherapy Submitted

Chapter 5 High-dose chemotherapy with autologous bone marrow support as consolidation after standard-dose adjuvant therapy in primary breast cancer patients with 7 or more involved axillary lymph nodes Bone Marrow Transplantation 1998;21:243-247

Chapter 6 HLA-matched allogeneic stem cell transplantation after reduced intensity (RIST) conditioning with Fludarabine/CTX in patients with metastatic breast cancer

Bone Marrow Transplantation 2010;45:464-467

Chapter 7 Summary, conclusions and future perspectives

Samenvatting

List of publications

Dankwoord

Curriculum Vitae 



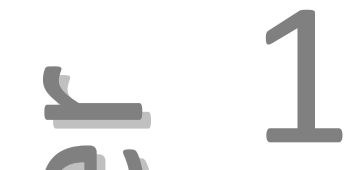

(1)

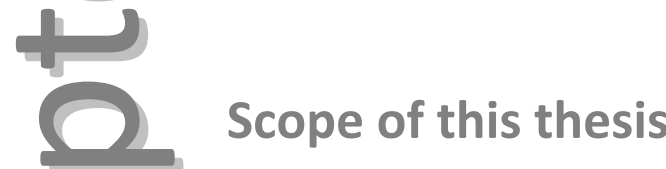

(0)

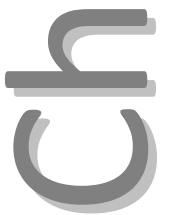





\section{Scope of this thesis}

In the past years several new therapeutic interventions in breast cancer were investigated and some were consecutively implemented in daily practice.

The introduction of systemic chemotherapy resulted in a modest improvement in the outcome of patients with disseminated breast cancer. Although the majority of patients with metastatic breast cancer will experience an initial response or stabilization of the disease on various combination chemotherapy regimens, relapses mostly occur within one year and the median overall survival after start of treatment is limited to on average two to three years. Attempts to improve these results by increasing the dose of chemotherapy has met only limited success, mainly due to profound myelosuppression. Hematopoietic growth factors, and particularly Granulocyte Colony Stimulating Factor (G-CSF), offer an opportunity to overcome this problem, but whether this will lead to better results remains to be determined. The aim of dose intensification is to increase the dose of treatment to the limit of normal tissue tolerance for the drugs used, with the intention of maximizing antitumor efficacy. Dose intensity, dose size and cumulative dose may each have important but different effects on outcome. According to the analysis of Goldie and Coldman the major effect of increased dose intensity is a more rapid and effective eradication of sensitive tumor cells, and with the dose size being the most important factor in reducing the chance of developing resistant cells.

Norton showed that a Gompertzian growth model precisely fitted in the growth curves of breast cancer. In this model, when a patient with advanced breast cancer is treated and the tumor mass is large, its growth fraction is low and the fraction of cells killed is low. Shortening of intervals ("dose-dense chemotherapy") may be important to overcome this cytokinetic resistance of tumors, by killing chemosensitive cells and recruiting regrowth of dormant cells, which will be killed by the subsequent cycle.

G-CSF can be used to obtain increased chemotherapy dose-intensity by allowing a higher dose of chemotherapy per course (dose-escalation) or by allowing a shortening of interval between courses (dose-dense). Both approaches may lead to a higher dose-intensity, but their biological effect and thereby clinical relevance may be quite different as has been pointed out by Henderson in his review on the dose-intensity phenomenon in breast cancer. The relative merits of these two approaches have not been studied systematically.

Chapter 2: "Comparative study of dose escalation versus interval reduction to obtain dose intensification of epirubicin and cyclophosphamide with Granulocyte-Colony Stimulating Factor (G-CSF) in advanced breast cancer" describes a randomized study with the aim to compare the maximal dose intensity of epirubicin and cyclophosphamide with the support of G-CSF, if given with fixed doses and decreasing intervals or with increasing doses and fixed intervals. The second aim was to assess the safety profiles of these intensified schedules. 
Anthracyclines and taxanes belong to the most active single agents in advanced breast cancer. Paclitaxel is highly active and lacks cross-resistance with other drugs commonly used in breast cancer treatment.

Chapter 3, "Dose dense epirubicin and paclitaxel with G-CSF: a study of decreasing intervals in metastatic breast cancer", describes a study with the aim of increasing the dose-intensity of the epirubicin and paclitaxel combination by shortening of the cycle time. The objective was to define the shortest feasible chemotherapy interval and to assess the safety profile of this approach.

Chapter 4, "Epirubicin and paclitaxel with G-CSF support in first line metastatic breast cancer: A randomized phase II study of dose-dense and dose-escalated chemotherapy", evaluates the efficacy and tolerability of two different doseintensified chemotherapy regimens of epirubicin and paclitaxel, supported with G-CSF.

Adjuvant chemotherapy has demonstrated a modest, but consistent improvement in long term disease-free and overall survival in primary breast cancer patients. The prognosis of patients with early breast cancer is inversely related to the number of involved axillary lymph nodes at surgery. Analysis of treatment outcomes in patients with 4-9 positive lymph nodes indicates that $60-70 \%$ will relapse by 10 years and for patients with 10 or more positive lymph nodes this is even worse, at 10 years $70-90 \%$ will have relapsed if no additional systemic treatment is provided. Attempts to further improve these results by increasing the dose of chemotherapy have met only limited success, mainly due to profound myelosuppression. Autologous stem cell transplantation offers an opportunity to overcome this problem, but whether this will lead to better results remains to be determined.

In Chapter 5, "High-dose chemotherapy with autologous bone marrow support as consolidation after standard-dose adjuvant therapy in primary breast cancer patients with $\mathbf{7}$ or more involved axillary lymph nodes", the question is being addressed whether adjuvant chemotherapy followed by high dose consolidation with busulfan and cyclophosphamide supported by autologous stem cell transplantation may improve the prognosis of patients with early breast cancer and 7 or more positive axillary lymph nodes.

In an addendum, the long-term follow-up data of the study of high-dose chemotherapy with autologous stem cell transplantation in high risk early breast cancer is given, with an overview of the literature on the role of high dose chemotherapy with autologous stem cell transplantation in the treatment of breast cancer. 
Chapter 6: "HLA-matched allogeneic stem cell transplantation after reduced intensity (RIST) conditioning with Fludarabine/CTX in patients with metastatic breast cancer", describes the largest single centre experience with RIST allogeneic stem cell transplantation in metastatic breast cancer. Purpose of this single centre study was to evaluate the feasibility, safety and efficacy of this therapeutic approach. Allogeneic transplantation of hematopoietic stem cells from an HLA-compatible donor has become the standard of care for several hematologic malignancies. Allogeneic transplantation not only replaces the marrow affected by the disease, but also exerts an immune graft-versus-tumor effect mediated by donor lymphocytes. The development of reduced intensity or non-myeloablative conditioning regimens for allogeneic transplantation has allowed this therapy to be used in elderly and disabled patients. An allogeneic graft-versus-tumor effect is observed in a proportion of patients with renal, breast, colorectal, ovarian, and pancreatic cancer treated with allogeneic transplantation.

Finally, Chapter 7 provides a summary and future perspectives. 



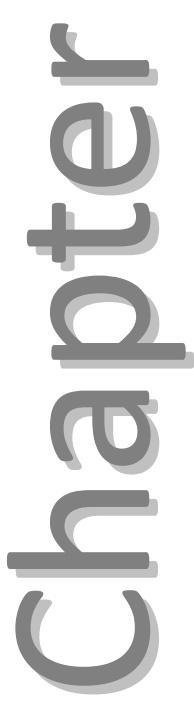

\section{Comparative study of dose escalation} versus interval reduction to obtain dose intensification of epirubicin and cyclophosphamide with G-CSF in advanced breast cancer

Lalisang RI, Wils JA, Nortier HW, Burghouts JTh, Hupperets PS, Erdkamp FL, Schouten HC, Blijham GH Journal of Clinical Oncology 1997;15:1367-1376 


\section{Summary}

Aims

A potential application of hematopoietic growth factors is to obtain an increased dose intensity. This can be achieved by either higher doses of chemotherapy with standard intervals, or by standard doses with shorter intervals. The potential of these approaches has not been investigated systematically.

\section{Patients and methods}

In a randomized, multicenter study, forty nine advanced breast cancer patients were treated with G-CSF and either increasing doses of epirubicin and cyclophosphamide with fixed intervals (arm 1) or progressively shorter intervals with fixed doses of epirubicin and cyclophosphamide (arm 2). A cohort of at least six patients was studied at each interval/dose. A more intensified interval/dose was given if less than $50 \%$ of patients encountered a dose intensity limiting criterium in the first three courses.

\section{Results}

In arm 1, epirubicin/cyclophosphamide $140 / 800 \mathrm{mg} / \mathrm{m}^{2}$ q 21 days was too toxic. Subsequently epirubicin/cyclophosphamide $120 / 700 \mathrm{mg} / \mathrm{m}^{2}$ was tested with two out of ten patients encountering a dose intensity limiting criterium. All initial dose intensity limiting criteria consisted of febrile neutropenia. In arm 2, epirubicin/cyclophosphamide $75 / 500 \mathrm{mg} / \mathrm{m}^{2}$ could be administered safely with fourteen and twelve days intervals. In the ten days interval eight out of twelve patients completed the first three cycles without a dose intensity limiting criterium. In the eight days interval seven out of eight patients encountered a dose intensity limiting criterium. Incomplete neutrophil recovery, and to a lesser extent stomatitis, were dose limiting.

\section{Conclusions}

In combination with G-CSF, epirubicin/cyclophosphamide $120 / 700 \mathrm{mg} / \mathrm{m}^{2}$ q 21 days was feasible with a projected dose intensity of $40 \mathrm{mg} / \mathrm{m}^{2} /$ week and $233 \mathrm{mg} / \mathrm{m}^{2} /$ week, respectively.

Epirubicin/cyclophosphamide $75 / 500 \mathrm{mg} / \mathrm{m}^{2}$ could be administered safely every ten days, allowing a higher projected dose intensity of $52.5 \mathrm{mg} / \mathrm{m}^{2} /$ week and $350 \mathrm{mg} / \mathrm{m}^{2} /$ week, respectively. 


\section{Introduction}

The use of systemic chemotherapy has not resulted in a major improvement in the outcome of patients with disseminated breast cancer. Although the majority of patients will experience an initial response or stabilization of the disease on various combination chemotherapy regimens, relapses will often occur within one year and the median survival after start of treatment is limited to two years. ${ }^{1,2}$ Attempts to improve these results by increasing the dose of chemotherapy has met only limited success, mainly due to profound myelosuppression. Hematopoietic growth factors offer an opportunity to overcome this problem ${ }^{3-7}$, but whether this will lead to better results remains to be determined. Cyclophosphamide and the anthracycline doxorubicin are the most active single agents in the first line treatment of advanced breast cancer, producing an overall response of $36 \%$ and $43 \%$, respectively. Since Canellos' report of the superior efficacy of combination chemotherapy over singleagent chemotherapy, these drugs are mostly given in combination. ${ }^{8} 4^{\prime}$-Epi-doxorubicin (epirubicin) is a synthetic doxorubicin analogue, which is reported to produce similar activity as Doxorubicin at equimolar doses with decreased overall toxicity, in particular cardiotoxicity. ${ }^{9}$ Several studies suggest a significant dose-response relationship for anthracyclines in breast cancer. ${ }^{10-14}$ High dose cyclophosphamide has been shown to induce responses in a variety of relapsed or refractory malignancies and has been part of double-alkylator therapy with autologous bone marrow rescue in advanced breast cancer. ${ }^{15,16}$ These clinical findings suggest a dose-response relationship for cyclophosphamide and anthracyclines in human cancers, including breast cancer, making them of interest to be combined with hematopoietic growth factors.

Hematopoietic growth factors can be used to obtain increased dose-intensity by allowing a higher dose of chemotherapy per course (dose-escalation) or by allowing a shortening of interval between courses (dose-dense). Both approaches may lead to a higher dose-intensity, but their biological effect and thereby clinical relevance may be quite different as has been pointed out by Henderson in his review on the doseintensity phenomenon in breast cancer. ${ }^{17}$ The relative merits of these two approaches have not been studied systematically.

Epirubicin $75 \mathrm{mg} / \mathrm{m}^{2}$ and cyclophosphamide $500 \mathrm{mg} / \mathrm{m}^{2}$ every three weeks is an active and frequently used chemotherapy regimen in (locally) advanced breast cancer. In an EORTC pilot study of (locally) advanced breast cancer, Piccart (personal communication) succeeded in escalation of the epirubicin/cyclophosphamide combination. In her selected patient group the maximal tolerable dose of a 3-week schedule epirubicin and cyclophosphamide, without hematopoietic growth factors, was $120 \mathrm{mg} / \mathrm{m}^{2}$ and $830 \mathrm{mg} / \mathrm{m}^{2}$, respectively.

Based on these considerations we performed a randomized study with the aim to compare the maximal dose intensity of epirubicin and cyclophosphamide with the support of the hematopoietic growth factor Granulocyte-Colony Stimulating Factor (G-CSF), if given with fixed doses and decreasing intervals or with increasing doses and 
fixed intervals. The second aim was to assess the safety profiles of these intensified schedules.

\section{Patients and methods}

\section{Patient selection}

Women with advanced breast cancer, between 18-70 years of age, an Eastern Cooperative Oncology Group (ECOG) performance status less than three and no prior chemotherapy for metastatic disease, were eligible. Patients may have received prior hormonal therapy for metastatic disease, adjuvant chemotherapy with/or without anthracyclines, if at entry the prior cumulative dose of doxorubicin or epirubicin did not exceed $300 \mathrm{mg} / \mathrm{m}^{2}$ and $450 \mathrm{mg} / \mathrm{m}^{2}$ respectively. Prior radiotherapy, provided involving not more than $25 \%$ of red bone marrow and provided patients had recovered from the acute toxicities, was allowed. Patients with symptomatic angina pectoris, congestive heart failure, myocardial infarction within the last year, irreversible arrhythmias or uncontrolled arterial hypertension were excluded. Patients with CNS involvement, psychologic problems impairing follow-up, neutrophils less than $2.000 / \mu \mathrm{l}$ or platelets less than $100.000 / \mu \mathrm{l}$, or serum creatinine level more than $1.2 \mathrm{mg} / \mathrm{dl}$ or serum total bilirubine more than $1.5 \mathrm{mg} / \mathrm{dl}$ were also ineligible. Informed consent was obtained before patients were included in the trial. Randomization was by a telephone to the study-coordinator and was stratified by hospital.

\section{Treatment plan}

This two-armed randomized schedule finding study was conducted in 6 hospitals in the Netherlands. In the study G-CSF (Filgrastim, Amgen Inc. Thousand Oaks, California, USA) was used.

Arm 1 consisted of increasing doses of epirubicin and cyclophosphamide at day 1 , with a fixed interval of 21 days. The G-CSF (300 $\mu \mathrm{gm}$ for patients $\leq 70 \mathrm{~kg}$ and $480 \mu \mathrm{gm}$ for patients $>70 \mathrm{~kg}$ ) was administered subcutaneously daily from day 2 till neutrophil recovery $(>1.500 / \mu \mathrm{l})$. The starting dose level of epirubicin/cyclophosphamide was $140 / 800 \mathrm{mg} / \mathrm{m}^{2}$, and it was planned to increase the dose to $160 / 900 \mathrm{mg} / \mathrm{m}^{2}$ and $180 / 1000 \mathrm{mg} / \mathrm{m}^{2}$, respectively. Due to severe toxicity (see results) this first level had to be closed early and subsequently a lower dose $120 / 700 \mathrm{mg} / \mathrm{m}^{2}$ was studied (Table 2.1).

Arm 2 consisted of shortening intervals with fixed doses of epirubicin $75 \mathrm{mg} / \mathrm{m}^{2}$ and cyclophosphamide $500 \mathrm{mg} / \mathrm{m}^{2}$ on day 1 , with the G-CSF administered from day 2 till the day before next cycle. The starting interval was 14 days, and was planned to be shortened to 12 and 10 days, respectively (Table 2.1). 
A cohort of at least six patients was studied at each interval/dose and changes in intervals or doses were done in subsequent cohorts of patients. No progressive dose escalation or interval shortening was allowed in the same patient.

For this study specific Dose-Intensity Limiting Criteria (DILC, see Table 2.2) had been defined. Proceeding to the next, more intensified, level took place after completing the previous cohort of patients and only if less than $50 \%$ of these patients had experienced a DILC during the first three courses.

Table 2.1 Treatment schedule.

\begin{tabular}{|c|c|c|c|}
\hline Arm/Level & $\begin{array}{l}\text { Epirubicin/Cyclophosphamide } \\
\qquad\left(\mathrm{mg} / \mathrm{m}^{2}\right)\end{array}$ & $\begin{array}{l}\text { Interval } \\
\text { days }\end{array}$ & $\begin{array}{c}\text { No. of } \\
\text { Patients }\end{array}$ \\
\hline \multicolumn{4}{|l|}{ Arm 1} \\
\hline Level 1.0 & $120 / 700$ & 21 & 10 \\
\hline Level 1.1 & $140 / 800$ & 21 & 3 \\
\hline Level 1.2 & 160 / 900 & 21 & - \\
\hline Level 1.3 & $180 / 1.000$ & 21 & - \\
\hline \multicolumn{4}{|l|}{ Arm 2} \\
\hline Level 2.1 & $75 / 500$ & 14 & 9 \\
\hline Level 2.2 & $75 / 500$ & 12 & 7 \\
\hline Level 2.3 & $75 / 500$ & 10 & 12 \\
\hline Level 2.4 & 75 / 500 & 8 & 8 \\
\hline
\end{tabular}

Table 2.2 Dose-intensity limiting criteria (DILC).

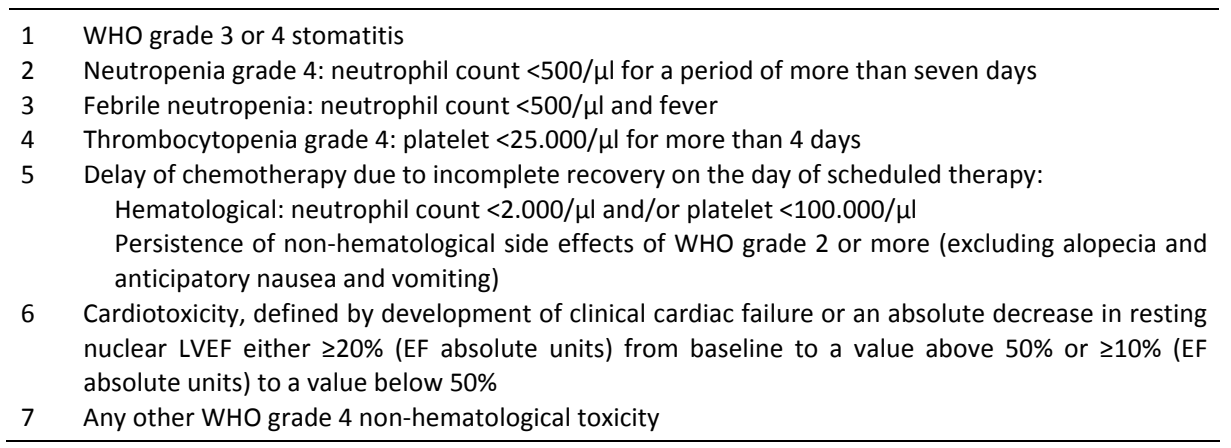

The patients had to complete a minimum of three cycles before considering to take them off study, except in case of disease progression, cardiac toxicity, unacceptable toxicity precluding further therapy or patients' refusal to continue treatment. Patients with an objective response or stable disease and without a DILC in the first three cycles continued the treatment at the same dose level they had entered the study as long as this was in the best interest of the patient.

Epirubicin and cyclophosphamide were administered by intravenous bolus injections. In both arms the neutrophils $(>2.000 / \mu \mathrm{l})$ and platelets $(>100.000 / \mu \mathrm{l})$ counts had to be recovered on the day of chemotherapy administration. In the first three cycles no 
dose adjustments on the basis of myelosuppression were allowed. In case of incomplete hematological recovery treatment was delayed and patients were scored as meeting a DILC. In case of WHO grade 3-4 stomatitis, diarrhea, vomiting during adequate antiemetic protection, or febrile neutropenia the doses of epirubicin and cyclophosphamide were reduced, and the patient was again scored as meeting a DILC. No concomitant other chemotherapy or hormonal therapy was permitted. Prophylactic antibiotic therapy, also after a period of febrile neutropenia, was left to the discretion of the investigator.

Patients were transfused when necessary to maintain a platelet count more than $15.000 / \mu \mathrm{l}$ and hemoglobin level more than $8.0 \mathrm{~g} / \mathrm{dl}$.

To express the dose-intensity of the treatments two equations were used. The Delivered Dose-Intensity (DDI) is defined as the actual given dose per $\mathrm{m}^{2}$ per week during the first three protocol cycles of treatment and the Maximum Tolerated DoseIntensity (MTDI) is the dose per $\mathrm{m}^{2}$ per week during the first three cycles of protocol treatment, that was found the maximum that could be tolerated.

\section{Pretreatment and follow-up evaluation}

Clinical staging was performed in all patients and included a complete history and physical examination with tumor measurements (if possible). Complete blood cell counts with differential and platelet counts were performed initially and repeated twice weekly after the start of therapy. A biochemical profile was assessed before each cycle. A baseline measurement of resting LVEF by multi-gated nuclear scan (MUGA) was requested, but was obligatory in patients with prior anthracycline containing adjuvant chemotherapy. Follow-up MUGA scan was requested in case of clinical signs of congestive heart failure, if patient went off study or at a cumulative dose of $500 \mathrm{mg} / \mathrm{m}^{2}$ epirubicin, at $800 \mathrm{mg} / \mathrm{m}^{2}$ and subsequently before each next treatment course thereafter. Staging procedures consisted of chest X-rays, bone scintigraphy followed by X-ray of suspected areas, and, if indicated, ultrasound and/or computer tomography scans of suspected areas. Tumor evaluation was repeated after three and six cycles, at the end of treatment or as clinically indicated and evaluated according to UICC-criteria. ${ }^{18}$ Toxicity of both regimens was assessed after each course according to WHO grading criteria ${ }^{18}$ except for neutropenia, thrombocytopenia, febrile neutropenia and cardiotoxicity for which adjusted criteria were applied (DILC 2, 3, 4 and 6; see Table 2.2).

\section{Results}

\section{Patient characteristics}

Fifty-three eligible patients were entered, four patients were found to be not evaluable, three patients because of an incorrect dosing of Cyclophosphamide and 
one because of incorrect G-CSF administration. Therefore, 49 patients were fully assessable for the present report. The characteristics of these 49 patients are shown in Table 2.3. These 49 patients underwent 197 cycles according protocol until DILC, progression or when stopping treatment was in best interest of patient. After meeting a DILC several patients continued the epirubicin/cyclophosphamide treatment with an adapted dose or schedule.

Initial DILC's in the first three cycles (see Table 2.4).

Table 2.3 Patient characteristics.

\begin{tabular}{|c|c|c|c|}
\hline Characteristics & No. of patients & & $\%$ \\
\hline Eligible / assessable & 49 & & \\
\hline Median age, years & & 50 & \\
\hline Range & & $31-68$ & \\
\hline Mean ECOG performance status & & 1 & \\
\hline Range & & $0-2$ & \\
\hline Locally advanced & 1 & & \\
\hline Metastatic & 48 & & \\
\hline Adjuvant chemotherapy & 11 & & \\
\hline \multicolumn{4}{|l|}{ Site of disease } \\
\hline Bone & 33 & & 69 \\
\hline Visceral & 25 & & 52 \\
\hline Soft tissue & 33 & & 69 \\
\hline \multicolumn{4}{|l|}{ No. of organs involved } \\
\hline Median & & 2 & \\
\hline Range & & $1-5$ & \\
\hline 1 & 8 & & \\
\hline 2 & 24 & & \\
\hline 3 & 8 & & \\
\hline 4 & 4 & & \\
\hline 5 & 4 & & \\
\hline Overall response & $35 / 47$ & & 74 \\
\hline Complete response & $7 / 47$ & & 15 \\
\hline Partial response & $28 / 47$ & & 60 \\
\hline Stable disease & $7 / 47$ & & 15 \\
\hline Not measurable & 2 & & \\
\hline
\end{tabular}

\section{Arm 1}

In arm 1 at the start (level 1.1) epirubicin/cyclophosphamide 140/800 mg/m q 21 days three patients were entered. All patients suffered febrile neutropenia and one of them also a stomatitis grade 3 after the first course; one patient also developed a WHO grade 4 thrombocytopenia. Because these first three patients of an intended cohort of six patients already met a DILC, this level was closed and a lower dose (level 1.0) was tested. Ten patients were tested on the level epirubicin/cyclophosphamide $120 / 700 \mathrm{mg} / \mathrm{m}^{2}$ q 21 days, with a median delivered dose intensity for epirubicin of 40 (37-41) $\mathrm{mg} / \mathrm{m}^{2} /$ week and for cyclophosphamide of $229(216-244) \mathrm{mg} / \mathrm{m}^{2} /$ week, respectively. Two patients encountered a DILC, febrile neutropenia in the first cycle. 
Given the considerable level of toxicity seen with epirubicin/cyclophosphamide $140 / 800 \mathrm{mg} / \mathrm{m}^{2}$ we decided not to test epirubicin/cyclophosphamide $130 / 750 \mathrm{mg} / \mathrm{m}^{2}$ q 21 days but to consider epirubicin/cyclophosphamide $120 / 700 \mathrm{mg} / \mathrm{m}^{2}$ to be the MTD at 21 days interval (Table 2.4). This would mean a MTDI for epirubicin of $40 \mathrm{mg} / \mathrm{m}^{2}$ and for cyclophosphamide of $233 \mathrm{mg} / \mathrm{m}^{2}$.

Table 2.4 Epirubicin/cyclophosphamide + G-CSF initial DILC during the first 3 cycles

\begin{tabular}{|c|c|c|c|c|c|c|}
\hline & \multicolumn{6}{|c|}{ Epirubicin / Cyclophosphamide $\left(\mathrm{mg} / \mathrm{m}^{2}\right)$} \\
\hline & $140 / 800$ & $120 / 700$ & $75 / 500$ & $75 / 500$ & $75 / 500$ & $75 / 500$ \\
\hline Treatment interval (days) & 21 & 21 & 14 & 12 & 10 & 8 \\
\hline No. of patients & 3 & 10 & 9 & 7 & 12 & 8 \\
\hline Patients with DILC & 3 & 2 & 0 & 1 & 4 & 7 \\
\hline \multicolumn{7}{|l|}{ Initial DILC } \\
\hline ANC-recovery & & & & & $1 C_{3}$ & $4 C_{1} 3 C_{2}$ \\
\hline Platelet-recovery & & & & & & $1 C_{2}^{b}$ \\
\hline Febrile Neutropenia & $3 C_{1}$ & $2 C_{1}$ & & & $1 C_{1}$ & \\
\hline Mucositis $\geq$ WHO 3 & $1 \mathrm{C}_{1}^{\mathrm{c}}$ & & & & & \\
\hline Nausea/vomitus $\geq$ WHO 3 & & & & & $1 C_{2}$ & \\
\hline Delay persistence $\geq$ WHO 2 & & & & $1 \mathrm{C}_{2}^{\mathrm{a}}$ & $1 \mathrm{C}_{2}^{\mathrm{a}}$ & \\
\hline
\end{tabular}

ANC, absolute neutrophil count; $C_{1}$, cycle one; $C_{2}$, cycle two; $C_{3}$, cycle three.

${ }^{a}$ Both patients had persistent WHO grade 2 stomatitis at the day of scheduled cycle $3 ;{ }^{b}$ One patient concurrent delayed platelet and absolute neutrophil count recovery at the day of scheduled cycle $3{ }^{c}{ }^{c}$ One patient concurrent febrile neutropenia and WHO grade 3 mucositis.

\section{Arm 2}

In arm 2 of decreasing intervals with fixed doses of epirubicin and cyclophosphamide $75 / 500 \mathrm{mg} / \mathrm{m}^{2}$, in the 14 days (level 2.1 ) and 12 days (level 2.2 ) interval none out of nine patients and one out of seven patients met a DILC during the first three cycles respectively. The patient in the 12 days interval meeting a DILC needed delay due to stomatitis WHO grade 2 on the day of scheduled third cycle. At the 10 days (level 2.1) interval four patients out of 12 had a DILC. Febrile neutropenia occurred in one patient during the first cycle, and one patient needed delay of the third cycle due to persistence of stomatitis grade 2 at the day of planned chemotherapy. One patient showed a delayed neutrophil recovery after the third cycle and in the fourth patient nausea/vomitus WHO grade 3 after the second cycle was observed. The median delivered dose-intensity for the first three cycles was: epirubicin 49 (31-58) $\mathrm{mg} / \mathrm{m}^{2} /$ week and cyclophosphamide 327 (207-384) mg/m²/week. Because still less than $50 \%$ of the patients had a DILC, an additional level with a eight days interval (level 2.4) was tested. The 8-day interval was too short, seven out of eight patients met a DILC during the first three cycles, making this level not feasible based on the predefined criteria. The initial DILC's in all these patients were a delay of the next cycle because of incomplete hematologic recovery: incomplete neutrophil recovery on the day of planned cycle 2 and cycle 3, four and two patients respectively. The 
seventh patient had an incomplete neutrophil and platelet recovery on the day of planned cycle 3.

\section{Cumulative toxicity}

Patients were treated at their intended dose or interval level for three cycles or less if a DILC occurred. Although they were formally taken off study, many of those not having a DILC continued with additional courses. Since toxicity was monitored this allowed to obtain data on new or cumulative toxicity.

\section{Arm 1}

Eight of ten patients at the $120 / 700 \mathrm{mg} / \mathrm{m}^{2}$ level had no DILC in the first three courses. Six of them went on to complete at least six cycles without additional DILC's. The kinetics of ANC and platelet counts of these patients over six courses are shown in Figure 2.1.
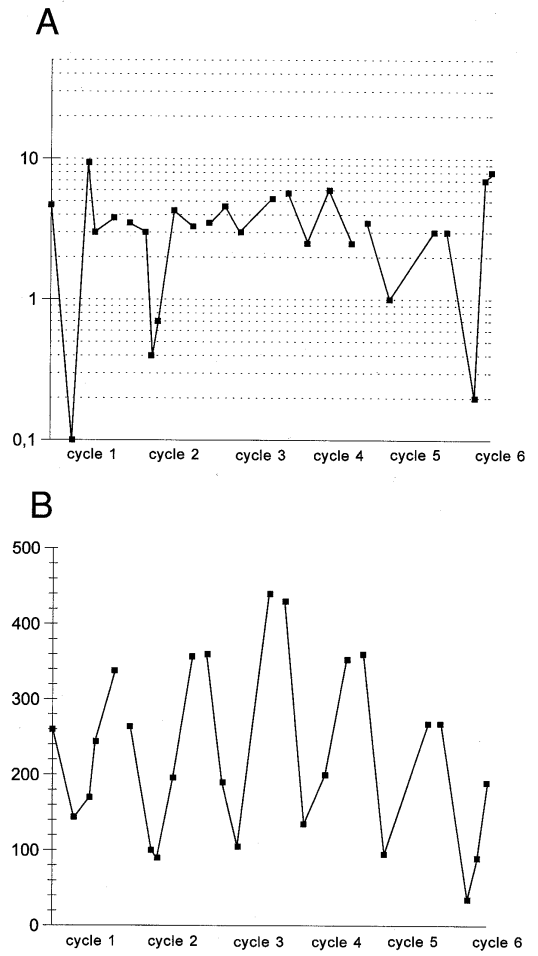

Figure 2.1 Epirubicin $120 \mathrm{mg} / \mathrm{m}^{2}$ and cyclophosphamide $700 \mathrm{mg} / \mathrm{m}^{2}$ plus G-CSF every 21 days; median values per day of consecutive chemotherapy cycles according to protocol: (A) neutrophils $(x 1,000 / \mu l),(B)$ platelets $(x 1,000 / \mu l)$ 


\section{Arm 2}

In the first cohort (14 days interval) no DILC's were observed during the first three courses. All (9) patients completed 45 cycles according to study protocol with a median of 5 per patient (range, 3-7). In one patient delay of the scheduled sixth cycle was necessary due to incomplete platelet recovery. In the 12 days interval six of seven patients had no DILC in the first three courses. They all went on with therapy to a median of 6 (range, 5-6) courses without any DILC.

In the 10 days interval eight of twelve patients had no DILC in the first three courses. They all continued therapy to a median of 6 (range, 4-9) courses. Two of these eight patients had a DILC during subsequent treatment, one in the fourth cycle (could not tolerate physically the shorter intervals and also asymptomatic cardiotoxicity) and one in the sixth cycle (stomatitis grade 3 ). The single patient in 8 days interval without a DILC in the first three courses, could complete an additional three courses without a DILC. The kinetics of ANC and platelet counts in the patients with 14, 12 and 10 days interval not having DILC in the first three courses are shown in figure 2.2. It appears that there is no cumulative neutropenia and thrombocytopenia over six courses, even in the eight patients treated with 10 days interval.

\section{Transfusion of blood cells}

The intense treatment resulted in anemia and the need for packed red cell transfusions in the majority of patients. Data are shown in Table 2.5 for the separate dose or interval levels. It appears that most transfusions occurred in the patients receiving three additional cycles of therapy. Platelet transfusion was indicated in 3 out of 13 patients in the arm with dose escalation, but not in the interval shortening arm.

Table 2.5 Transfusion of erythrocytes.

\begin{tabular}{lcccccc}
\hline & \multicolumn{2}{c}{ Dose escalation $\left(\mathrm{mg} / \mathrm{m}^{2}\right)$} & \multicolumn{4}{c}{ Interval reduction (days) } \\
& $140 / 180$ & $120 / 700$ & 14 & 12 & 10 & 8 \\
\hline No. of patients & 3 & 10 & 9 & 7 & 12 & 8 \\
Transfused cycle 1-3 & $2 / 3$ & $3 / 10$ & $1 / 9$ & $1 / 7$ & $2 / 12$ & $2 / 8$ \\
Transfused cycle 3+ & $2 / 3$ & $4 / 8$ & $2 / 9$ & $4 / 7$ & $7 / 11$ & $6 / 8$ \\
Total patients transfused & $2 / 3$ & $4 / 10$ & $2 / 9$ & $5 / 7$ & $8 / 12$ & $6 / 8$ \\
\hline
\end{tabular}

\section{Cardiotoxicity}

In our study cardiac toxicity was defined as development of clinical cardiac failure or an absolute decrease in resting LVEF either $\geq 20 \%$ (EF absolute units) to a value above $\geq 50 \%$ or $\geq 10 \%$ (EF absolute units) to a value below $50 \%$. During the study period no clinical symptoms of congestive heart failure or ECG abnormalities were observed. Basal and follow-up nuclear MUGA LVEF's were available in 26 of 49 patients, making them evaluable for cardiotoxicity by ejection fraction. A pathological, decline in LVEF 
as defined above was observed in three patients, all treated in the 10 or 8 days intervals. In the first patient follow-up MUGA scan eight days after the fifth course showed a decrease from baseline level $64 \%$ to $48 \%$. The second patient was admitted three days after the third course with a collapse, dyspnoea, non neutropenic fever and severe anemia (4,5 gr/dl). ECG showed sinus tachycardia without further abnormalities. MUGA scan showed a LVEF decrease from baseline $64 \%$ to $40 \%$. In the third patient the LVEF after the third cycle showed a decrease from $65 \%$ (baseline) to $48 \%$. Therefore, 3 out of 14 (21\%) patients treated in the shorter intervals and evaluable for cardiotoxicity showed a pathological decline, according the DILC criterium. These 3 patients were not previously treated with chemotherapy, and the cumulative dose of Epirubicin at the time of this observation ranged from 225 to $450 \mathrm{mg} / \mathrm{m}^{2}$. The follow-up LVEF's were performed between three and ten days after the last chemotherapy course. Additional follow-up LVEF measurements in the second patient (14 days later 53\%), in the third patient (8 months later 62\%) showed normalization in 2 out of these 3 patients; in the first patient no further measurements were available. However, six months later no cardiac clinical symptoms were present.
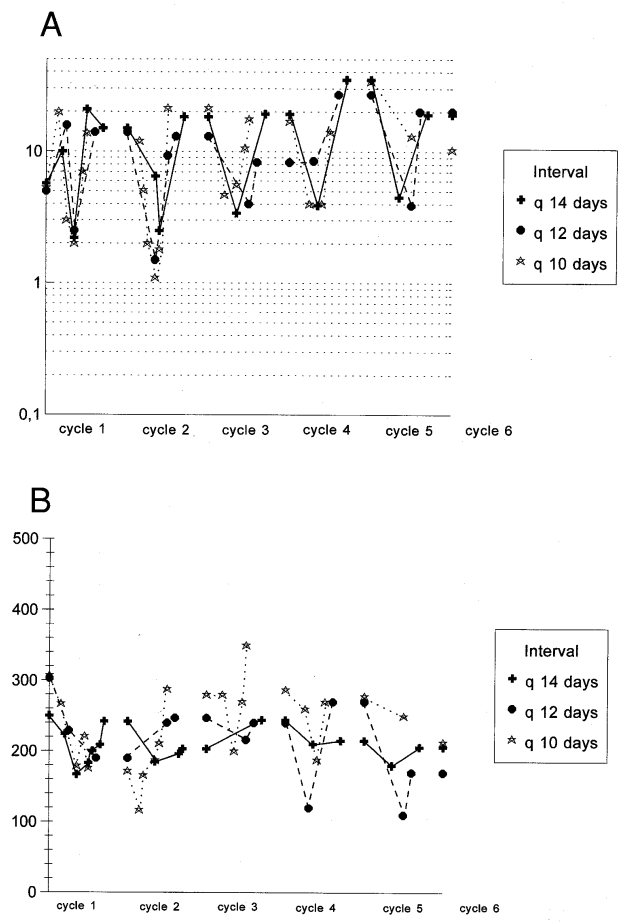

Figure 2.2 Interval-shortening epirubicin $75 \mathrm{mg} / \mathrm{m}^{2}$ and cyclophosphamide $500 \mathrm{mg} / \mathrm{m}^{2}$ plus G-CSF, 14$12-$, and 10-day intervals. Median values per day of consecutive chemotherapy cycles according to protocol: (A) neutrophils $(1,000 / \mu \mathrm{l})$, (B) platelets $(1,000 / \mu \mathrm{l})$. 


\section{Response Rate}

Efficacy was not an aim of this study. However, formal UICC criteria were applied to the 47 patients with measurable disease. An objective response was observed in 34 out of $46(74 \%)$ patients with metastatic disease, complete response in seven and partial response in 27 patients, respectively. Stable disease was observed in seven patients. The single patient with locally advanced disease had a partial response.

\section{Discussion}

The aim of our study was to determine the maximal dose intensity of epirubicin in combination with cyclophosphamide in patients with metastatic breast cancer, supported by the hematopoietic growth factor G-CSF, but without hematopoietic stem cell support. Two approaches were studied: increasing the dose in individual cycles with a fixed interval and decreasing the interval with a fixed dose.

With dose escalation of epirubicin and cyclophosphamide with G-CSF in a 3 week schedule a maximal tolerable dose of $120 \mathrm{mg} / \mathrm{m}^{2}$ and $700 \mathrm{mg} / \mathrm{m}^{2}$ respectively, was achieved. Dose limiting toxicity was febrile neutropenia. It was observed in two out 10 patients at this dose level, but occurred in three out of three patients treated with $140 \mathrm{mg} / \mathrm{m}^{2}$ epirubicin and $800 \mathrm{mg} / \mathrm{m}^{2}$ cyclophosphamide. Piccart investigated epirubicin/cyclophosphamide $120 / 830 \mathrm{mg} / \mathrm{m}^{2}$ with the addition of G-CSF in locally advanced and metastatic breast cancer in cohorts of decreasing intervals. ${ }^{7}$ The minimal tolerable interval was 14 days, with the G-CSF administered from day 2-13. Dose limiting toxicity was encountered in five out of 12 patients, 2 patients with severe non-hematologic toxicity (mucositis and skin toxicity), and 3 patients with febrile neutropenia. From our and Piccart's data it appears that $120-130 \mathrm{mg} / \mathrm{m}^{2}$ epirubicin in combination with moderate dose $\left(700-830 \mathrm{mg} / \mathrm{m}^{2}\right)$ cyclophosphamide is the maximum tolerated dose. Although G-CSF will accelerate the recovery from the ANC nadir, this does not allow significant dose escalation as evidenced by our findings in the epirubicin/cyclophosphamide $140 / 800 \mathrm{mg} / \mathrm{m}^{2}$ cohort. The MTDI in our study was therefore set at $40 \mathrm{mg} / \mathrm{m}^{2} /$ week of epirubicin and $233 \mathrm{mg} / \mathrm{m}^{2} /$ week of cyclophosphamide. It remains unclear whether further escalation of the dose of this particular combination can be achieved by adding hematopoietic stem cell support.

Shortening of intervals with epirubicin $75 \mathrm{mg} / \mathrm{m}^{2}$ and cyclophosphamide $500 \mathrm{mg} / \mathrm{m}^{2}$ with G-CSF support, permitted a minimal tolerable interval of 10 days, allowing a median delivered dose intensity for epirubicin of $49 \mathrm{mg} / \mathrm{m}^{2} /$ week and cyclophosphamide $327 \mathrm{mg} / \mathrm{m}^{2} /$ week and a MTDI of $52,5 \mathrm{mg} / \mathrm{m}^{2} /$ week for epirubicin and of $350 \mathrm{mg} / \mathrm{m}^{2} /$ week for cyclophosphamide. Therefore, reducing intervals with standard dose is more effective in increasing dose intensity than dose escalation with standard intervals. Some escalation of the dose of $75 \mathrm{mg} / \mathrm{m}^{2}$ epirubicin and $500 \mathrm{mg} / \mathrm{m}^{2}$ cyclophosphamide per course may be possible making an even higher dose-intensity achievable. 
An important aspect of studies on escalated dose intensities is whether this can be maintained over repeated cycles. Conceivably with intervals as short as 10 days and retreatment at the moment of rapid recovery the population of progenitor cells may be vulnerable to the repetitive cytotoxic insults and may become exhausted after a number of cycles. Although we have only data collected over six cycles, we have not observed signs of exhaustion. It may well be that in fact the treatment with G-CSF till 24 hours before the next chemotherapy has protected progenitor cells by putting them out of cycle as has been suggested by Vadhan-Raj et al. using GM-CSF. ${ }^{19}$ Also thrombocytopenia has rarely been dose limiting, even after 6 cycles of epirubicin/cyclophosphamide at the 10 days interval. Further data on larger numbers of patients with even more cycles are needed to determine the absence of cumulative myelosuppression with certainty.

We observed a clinically asymptomatic cardiotoxicity in $21 \%$ of patients treated with the shorter intervals, that appeared however reversible with longer follow-up. A possible explanation for the temporary pathologic decline may be the short interval between chemotherapy administration and the LVEF measurement, suggesting a reversible myocardial injury through free radicals induced by epirubicin and its toxic metabolites. ${ }^{20}$ This possibly more frequent cardiotoxicity needs further careful evaluation.

Since Bronchud's initial report, applying doxorubicin in combination with G-CSF, several investigators have explored dose intensification with CSF's in the treatment of advanced breast cancer in phase $\mathrm{I} / \mathrm{II}$ studies (Table 2.6). ${ }^{3,6,7,21-23} \mathrm{In}$ different schedules and combinations maximal tolerable dose intensities of $55 \mathrm{mg} / \mathrm{m}^{2} /$ week of epirubicin in combination with $350 \mathrm{mg} / \mathrm{m}^{2} /$ week of cyclophosphamide could be reached. This is an increase of dose intensity from standard epirubicin/cyclophosphamide treatment with a factor 2,1. In these selected patients promising response rates, with a relatively high percentage of complete remissions, were achieved. From a study of anthracycline containing adjuvant therapy in breast cancer it is known that differences of a factor 2 may make a difference in outcome ${ }^{14}$. Whether this is also the case in metastatic breast cancer cannot be concluded from the present studies.

Table 2.6 Dose-intensification with CSF support in metastatic beast cancer.

\begin{tabular}{|c|c|c|c|c|c|c|}
\hline \multirow{2}{*}{$\begin{array}{l}\text { First author } \\
\text { and reference }\end{array}$} & \multirow{2}{*}{$\begin{array}{l}\text { Treatment Schedule } \\
\left(\mathrm{mg} / \mathrm{m}^{2}\right)\end{array}$} & & & \multirow[b]{2}{*}{ CSF } & \multicolumn{2}{|c|}{ Response \% } \\
\hline & & & & & OR & CCR \\
\hline Bronchud $^{3}$ & D 120 every 12 days & $\mathrm{D}$ & 70 & G-CSF & 74 & 21 \\
\hline Hoekman $^{6}$ & D/C 90/1,000 every 21 days & $\mathrm{D} / \mathrm{C}$ & $30 / 333$ & GM-CSF & 80 & 20 \\
\hline Scinto $^{21}$ & E/C $120 / 600$ every 14 days & $E / C$ & $60 / 300$ & G-CSF & 86 & 50 \\
\hline Lalisang & E/C 75/500 every 10 days & $\mathrm{E} / \mathrm{C}$ & $52.5 / 350$ & G-CSF & 74 & 15 \\
\hline Piccart $^{7}$ & E/C $120 / 830$ every 14 days & $E / C$ & $60 / 415$ & G-CSF & 87 & 20 \\
\hline Marangalo 22 & E 150 every 15 days & $\mathrm{E}$ & 70 & G-CSF & - & - \\
\hline Ardizonni $^{23}$ & F/E/C $600 / 60 / 600$ every 16 days & $\mathrm{F} / \mathrm{E} / \mathrm{C}$ & $260 / 26 / 260$ & GM-CSF & - & - \\
\hline
\end{tabular}

GM-CSF = granulocyte-macrophage colony-stimulating factor, $\mathrm{D}=$ doxorubicin, $\mathrm{E}=$ epirubicin, $\mathrm{C}=$ cyclophosphamide $\mathrm{F}=5$-fluoro-uracil 
The aim of dose intensification is to increase the dose of treatment to the limit of normal tissue tolerance for the drugs used, with the intention of maximizing anti tumor efficacy. Dose intensity, dose size and cumulative dose may each have important but different effects on outcome. According to the analysis of Goldie and Coldman the major effect of high dose intensity is a more rapid and effective eradication of sensitive tumor cells and the dose size the most important factor in reducing the chance of developing resistant cells. ${ }^{24,25}$

Norton showed that a Gompertzian growth model precisely fitted in the growth curves of breast cancer. ${ }^{26,27}$ In this model, when a patient with advanced breast cancer is treated and the tumor mass is large, its growth fraction is low and the fraction of cells killed is low. Shortening of intervals ("dose-dense chemotherapy") may be important to overcome the cytokinetic resistance of tumors, by killing chemosensitive cells and recruiting regrowth of dormant cells, which will be killed by the subsequent cycle. $^{28}$ Therefore on theoretical grounds, treatment of advanced breast cancer may start with short repetitive cycles of effective dose (dose-dense) chemotherapy, followed by increased dose size (dose-escalated) chemotherapy.

In conclusion, with the addition of G-CSF, shortening of intervals between standard doses of chemotherapy in comparison with increasing doses and fixed intervals, seems to be an effective method of dose intensification, allowing a projected dose intensity of $52,5 \mathrm{mg} / \mathrm{m}^{2} /$ week of epirubicin in combination with $350 \mathrm{mg} / \mathrm{m}^{2} /$ week of cyclophosphamide. The efficacy and clinical relevance of this approach, that on theoretical grounds may be particularly attractive in the early phase of the treatment of patients with metastatic breast cancer, must be demonstrated in further studies. 


\section{References}

1. Henderson IC, Garber JE, Breitmeyer JB. Comprehensive management of disseminated breast cancer. Cancer 1990;66:1439-1448.

2. Garber JE, Henderson IC. The use of chemotherapy in metastatic breast cancer. Hematol Oncol Clin North Am 1989;3:807-821.

3. Bronchud MH, Howell A, Crowther D, Hopwood P, Souza L, Dexter TM. The use of granulocyte colonystimulating factor to increase the intensity of treatment with doxorubicin in patients with advanced breast and ovarian cancer. Br J Cancer 1989;60:121-125.

4. Neidhart J, Mangalik A, Kohler W, Stidley C, Saiki J, Duncan P, Souza L, Downing M. Granulocyte colony-stimulating factor stimulates recovery of granulocytes in patients receiving dose-intensive chemotherapy without bone marrow transplantation. J CLin Oncol 1989;7:1685-1692.

5. Neidhart JA, Mangalik A, Stidley CA, Tebich SL, Sarmiento LE, Pfile JE, Oette DH, Oldham FB. Dosing regimen of granulocyte-macrophage colony-stimulating factor to support dose-intensive chemotherapy J Clin Oncol 1992:10:1460-1469.

6. Hoekman K, Wagstaff J, van Groeningen CJ, Vermorken JB, Boven E, Pinedo HM. Effects of recombinant human granulocyte-macrophage colony-stimulating factor on myelosuppression induced by multiple cycles of high-dose chemotherapy in patients with advanced breast cancer. J Natl Cancer Inst 1991;83:1546-1553.

7. Piccart MJ, Bruning P, Wildiers J, Awada A, Schornagel JH, Thomas J, Tomiak E, Bartholomeus S, Witteveen PO, Paridaens R. An EORTC pilot study of filgrastim (recombinant human granulocyte colony stimulating factor) as support to high dose-intensive epiadriamycin-cyclophosphamide regimen in chemotherapy-naive patients with locally advanced or metastatic breast cancer. Ann Oncol 1995; 6:673-677.

8. Canellos GP, Pocock SJ, Taylor SG 3rd, Sears ME, Klaasen DJ, Band PR. Combination chemotherapy for metastatic breast carcinoma. Prospective comparison of multidrug therapy with L-Phenylalanine mustard. Cancer 1976;38:1882-1886.

9. Jain KK, Casper ES, Geller NL, Hakes TB, Kaufman RJ, Currie V, Schwartz W, Cassidy C, Petroni GR, Young $\mathrm{CW}$, et al. A prospective randomized comparison of Epirubicin and Doxorubicin in patients with advanced breast cancer. J Clin Oncol 1985;3:818-826.

10. Jones RB, Holland JF, Bhardwaj S, Norton L, Wilfinger C, Strashun A. A phase I-II study of intensivedose Adriamycin for advanced breast cancer. J CLin Oncol 1987;5:171-177.

11. Ang PT, Buzdar AU, Smith TL, Kau S, Hortobagyi GN. Analysis of dose intensity in doxorubicincontaining adjuvant chemotherapy in stage II and III breast carcinoma. J Clin Oncol 1989;7:1677-1684.

12. Focan C, Andrien JM, Closon MT, Dicato M, Driesschaert P, Focan-Henrard D, Lemaire M, Lobelle JP, Longree L, Ries F. Dose-response relationship of Epirubicin-based first line chemotherapy for advanced breast cancer. A prospective randomized trial. J Clin Oncol 1993;11:1253-1263.

13. Marschner N, Kreienberg R, Souchon R, Räth U, Eggeling B, Voigtmann R, Ruffert K, Schütte M, Ammon A, Kesztyüs T. Kaplan E, Nagel G. Evaluation of the importance and relevance of dose intensity using Epirubicin and Cyclophosphamide in metastatic breast cancer: Interim analysis of a prospective randomized trial. Sem Oncol 1994;21 (1Suppl 1):10-16.

14. Wood CW, Budman DR, Korzun AH, Cooper MR, Younger J, Hart RD, Moore A, Ellerton JA, Norton L, Ferree CR, Colangelo Ballow A, Frei E, Henderson IC. Dose and dose intensity of adjuvant chemotherapy for stage II, node-positive breast carcinoma. N Engl Med 1994;330:1253-1259.

15. Collins C, Mortimer J, Livingston RB. High-dose cyclophosphamide in the treatment of refractory lymphomas and solid tumour malignancies. Cancer 1989;63:228-232.

16. Peters WP, Eder JP, Henner WD, Schryber S, Wilmore D, Finberg R, Schoenfeld D, Bast R, Gargone B, Antman K. High-dose combination alkylating agents with autologous bone marrow support: a phase I trial. J Clin Oncol 1986;4:646-654.

17. Henderson IC, Hayes DF, Gelman R. Dose-response in the treatment of breast cancer. J Clin Oncol 1988; 6:1501-1516.

18. Miller AB, Hoogstraten B, Staquet M, Winkler A. Reporting results of cancer treatment. Cancer 1981; 47:207-214. 
19. Vadhan-Raj S, Broxmeyer HE, Hittelman WN, Papadopoulos NE, Chawla SP, Fenoglio C, Cooper S, Buescher ES, Frenck RW Jr, Holian A, et al. Abrogating chemotherapy-induced myelosuppression by recombinant granulocyte-macrophage colony-stimulating factor in patients with sarcoma: Protection at the progenitor cell level. J Clin Oncol 1992;10:1266-1277.

20. Doroshow JH, Akman S, Chu F-F, Esworthy S. Role of the glutathione-glutathione peroxydase cycle in the cytotoxicity of the anticancer quinones. Pharmacol Ther 1990;47:359-370.

21. Scinto AF, Ferraresi V, Campioni N, Tonachella R, Piarulli L, Sacchi I, Giannarelli D, Cognetti F. Accelerated chemotherapy with high-dose epirubicin and cyclophosphamide plus r-met-HUG-CSF in locally advanced and metastatic breast cancer. Ann Oncol 1995; 6:665-671.

22. Rosti G, Albertazzi L, Ferrante $P$, Nicoletti $P$, Morandi $P$, Bari M, Macchi S, Monti G, Argnani M, Sebastiani L, Marangolo M. Epirubicin + G-CSF as peripheral blood progenitor cells (PBPC) mobilising agents in breast cancer patients Ann Oncol 1995;6:1045-1047.

23. Ardizzonni A, Venturini M, Setoli MR, Giannessi PG, Brema F, Danova M, Testore F, Mariani GL, Pennucci MC, Queirolo P, Silvestro S. Bruzzi P. Lionetto R, Latini F, Rosso R. Granulocyte-Macrophage Colony-Stimulating factor (GM-CSF) allows acceleration and dose-intensity increase of CEF chemotherapy: a randomized study in patients with advanced breast cancer. $\mathrm{Br} \mathrm{J}$ Cancer 1994; 69:385-391.

24. Goldie $\mathrm{JH}$, Coldman AJ. A mathematical model for relating the drug sensitivity of tumour to the spontaneous mutation rate. Cancer Treat Rep 1979;63:1727-1733.

25. Gurney H, Dodwell D, Thatcher N, Tattersall MH. Escalating drug delivery in cancer chemotherapy: A review of concepts and practice (Part 1 and 2). Ann Oncol 1994;4:23-34 and 103-115.

26. Norton LA. A Gompertzian model of human breast cancer growth. Cancer Res 1988; 48:7067-7071.

27. Norton LA, Day R. Potential innovations in scheduling cancer chemotherapy, in: DeVita VT, Hellman S, Rosenberg SA (eds): Important advances in oncology.Philadelphia, PA, Lippincott, 1991;57-7324.

28. Hudis C, Seidman A, Raptis G, Fennelly D, Gilewski T, Baselga J, Theodoulou M, Sklarin N, Moynahan M, Surbone A, Currie V, Lebwohl D, Uhlenhopp M, Crown J, Norton L. Sequential Adjuvant Therapy: The Memorial Sloan-Kettering Cancer Centre Experience. Sem Oncol 1996;23 (Suppl 1):58-64. 


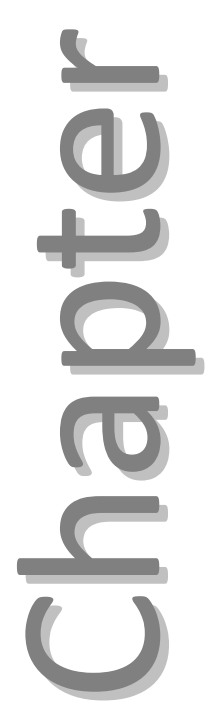

Dose dense epirubicin and paclitaxel with G-CSF: a study of decreasing intervals in metastatic breast cancer

Lalisang RI. Voest EE, Wils JA, Nortier JW, Erdkamp FL, Hillen HF, Wals J, Schouten HC, Blijham GH

British Journal of Cancer 2000;82:1914-1919 


\section{Summary}

\section{Background}

Anthracyclines and taxanes are very effective drugs in the treatment of advanced breast cancer. With G-CSF support, the dose-intensity of this combination can be increased by reducing the interval between chemotherapy cycles, the so-called "shortening of cycle time".

\section{Patients and Methods}

We treated 36 patients with advanced breast cancer in a multicenter phase $1 / / 1$ study. The treatment regimen consisted of epirubicin $75 \mathrm{mg} / \mathrm{m}^{2}$ followed by paclitaxel $135 \mathrm{mg} / \mathrm{m}^{2}$ (three hours) in combination with G-CSF $(5 \mu \mathrm{g} / \mathrm{kg})$. At least six patients were treated in each cohort and were evaluated over the first three cycles.

\section{Results}

Starting at an interval of 14 days in subsequent cohorts of patients the interval could be shortened to ten days. The eight-days interval was not feasible mainly due to incomplete neutrophil recovery at the day of the next scheduled cycle. In the cohort of ten days interval it was feasible to increase the paclitaxel dose to $175 \mathrm{mg} / \mathrm{m}^{2}$. The hematological and non-hematological toxicity was relatively mild. No cumulative myelosuppression was observed over at least three consecutive cycles.

\section{Conclusion}

In combination with G-CSF, epirubicin $75 \mathrm{mg} / \mathrm{m}^{2}$ and paclitaxel $175 \mathrm{mg} / \mathrm{m}^{2}$ could be safely administered every ten days over at least three cycles, enabling a dose intensity of 52 and $122 \mathrm{mg} / \mathrm{m}^{2} /$ week, respectively. 


\section{Introduction}

Anthracyclines and taxanes belong to the most active single agents in advanced breast cancer. Paclitaxel is highly active and lacks cross-resistance with other drugs commonly used in breast cancer treatment. ${ }^{1,2}$ Studies of single agent paclitaxel demonstrate that leucopenia is frequent and dose limiting in all schedules (3-, 6-, 24-hour infusion) evaluated. Randomized trials evaluating the 3- and/or 24-hour schedules, each with two paclitaxel doses of 135 and $175 \mathrm{mg} / \mathrm{m}^{2}$, have revealed that neutropenia is dose- and schedule-dependent, without apparent difference in efficacy. ${ }^{3,4,5}$ The optimal therapeutic schedule of paclitaxel is still unknown and on practical grounds, the short infusion over three hours is safe, convenient and effective. $^{6}$

Paclitaxel at longer infusion rate ( $\geq 24$ hours) has been given in combination with doxorubicin. The maximal tolerable dose (MTD) and toxicities (primarily mucositis and neutropenia) of this combination appear to depend on the sequence and infusion duration of the two drugs. ${ }^{7,8,9}$ In a study of escalating doses paclitaxel (3-hr infusion) in combination with fixed dose of doxorubicin $\left(60 \mathrm{mg} / \mathrm{m}^{2}\right.$ iv bolus) in a 3 weekly schedule, mucositis, long lasting grade 4 and febrile neutropenia defined the MTD of paclitaxel at $200 \mathrm{mg} / \mathrm{m}^{2}$, and was not sequence dependent. This regimen was very effective in chemotherapy-naive breast cancer patients, but at the cost of considerable increased cardiotoxicity. ${ }^{10,11} 4^{\prime}$-Epi-doxorubicin (epirubicin) is a synthetic doxorubicin analogue, with similar activity but decreased toxicity, in particular cardiotoxicity. ${ }^{12}$ It may therefore be an attractive substitute for doxorubicin in combination with taxanes.

Granulocyte colony stimulating factor (G-CSF) can be used to prevent neutropenia and to obtain increased dose-intensity by allowing a higher dose of chemotherapy per cycle (dose-escalation) or by allowing a shortening of interval between cycles (dosedense). Both approaches may lead to a higher dose-intensity, but their biological effect and clinical relevance may be quite different. ${ }^{13}$ These two approaches were investigated by our group in the treatment of metastatic breast cancer with epirubicin and cyclophosphamide. We concluded that with the addition of G-CSF interval reduction safely permitted a higher dose-intensity than dose escalation. ${ }^{14}$ Based on these results we started a study with the aim of increasing the dose-intensity of the epirubicin and paclitaxel combination by shortening of the cycle time. We intended to define the minimal tolerable interval of epirubicin $75 \mathrm{mg} / \mathrm{m}^{2}$ (iv bolus) followed by paclitaxel $135 \mathrm{mg} / \mathrm{m}^{2}$ (3-hour infusion) in combination with G-CSF support. The second aim was to assess the safety profile of this approach. 


\section{Materials and methods}

\section{Patient selection}

Women with advanced breast cancer were accrued in this multi-centre open-label schedule finding study. The study protocol was approved by the institutional review boards of the participating hospitals, and patients had to give informed consent. Criteria for inclusion were as follows: histological proof of breast cancer; age 18 to 70 years; performance status 0 to 2 (Eastern Cooperative Oncology Group [ECOG] scale), neutrophil count $\geq 2,000 / \mu \mathrm{l}$ and platelet count $\geq 100,000 / \mu \mathrm{L}$; adequate function tests for liver (bilirubin level $<1.5 \mathrm{mg} / \mathrm{dl}$ and transaminase levels $<3$ times upper limit of normal) and kidneys (serum creatinine level $<1.2 \mathrm{mg} / \mathrm{dl}$ ); no prior chemotherapy for metastatic disease; prior adjuvant chemotherapy allowed, if interval last chemotherapy cycle $\geq 1$ year and at entry cumulative dose of doxorubicin $\leq 300 \mathrm{mg} / \mathrm{m}^{2}$ and epirubicin $\leq 450 \mathrm{mg} / \mathrm{m}^{2}$; prior radiotherapy involving $\leq 25 \%$ of red bone marrow; LVEF by multigated isotope cardiography (MUGA-scan) $\geq 50 \%$ and without symptomatic cardiovascular disease; no central nervous system involvement.

\section{Treatment Plan}

In this schedule-finding study, the epirubicin (Pharmacia \& Upjohn, Milan, Italy), paclitaxel (Taxol, Bristol-Myers Squibb Pharmaceuticals, Princeton, NJ) as well as R-metHuG-CSF (Filgrastim, Amgen Inc. Thousands Oaks, CA) dose was kept constant, and four intercyclic intervals were foreseen. The starting interval of 14 days, was planned to be decreased to 12, 10 and 8 days, respectively. To prevent hypersensitivity reactions due to paclitaxel formulated in cremophor EL a routine premedication regimen was adopted: oral or intravenous dexamethason $20 \mathrm{mg}$ (6 and 12 hours pre-treatment); clemastine $2 \mathrm{mg}$ and ranitidine $50 \mathrm{mg}$ both intravenously 30-60 minutes before paclitaxel administration. Epirubicin was given as a short I.V. infusion on day 1 at a fixed dose of $75 \mathrm{mg} / \mathrm{m}^{2}$. Paclitaxel at a dose of $135 \mathrm{mg} / \mathrm{m}^{2}$ was administered by a 3-hour infusion, starting five minutes after epirubicin administration. G-CSF (300 $\mu \mathrm{gm}$ for patients $\leq 70 \mathrm{~kg}$ and $480 \mu \mathrm{gm}$ for patients $>70 \mathrm{~kg}$ ) was administered once daily on all days except the days of chemotherapy.

A cohort of at least six patients was studied at each interval. The neutrophil $(\geq 2,000 / \mu \mathrm{l})$ and platelet $(\geq 100,000 / \mu \mathrm{l})$ counts had to be recovered on the day of scheduled chemotherapy.

For this study specific Dose-Intensity Limiting Criteria (DILC, see Table 3.1) had been defined. Proceeding to the next, shorter interval level was done only after completion of the previous cohort and if less than $50 \%$ of these patients had experienced a DILC during the first three courses. In case of incomplete hematological recovery treatment was delayed. Concomitant hormonal therapy or prophylactic antibiotic therapy was not allowed. Patients were transfused when necessary to maintain a platelet count of $\geq 15,000 / \mu \mathrm{l}$ and hemoglobin level $\geq 8.0 \mathrm{~g} / \mathrm{dl}$. 
The patients had to complete a minimum of three cycles, except in case one of the following events occurred: disease progression, DILC, any other unacceptable toxicity precluding further therapy or patients' refusal to continue treatment. After completion of the first three cycles further therapy was left at the discretion of the investigator.

As the eight-day interval appeared to be not feasible (see results) a new cohort was tested in the 10-day interval with a higher paclitaxel dose of $175 \mathrm{mg} / \mathrm{m}^{2}$.

The MTD for this study was defined as the maximum dose that resulted in less than $50 \%$ instances of DILC's among treated patients in each cohort. To express the doseintensity of the treatment the equation, Delivered Dose-Intensity (DDI): the actually given dose per $\mathrm{m}^{2}$ per week during the first three protocol cycles of treatment, was used.

Table 3.1 Dose-intensity Limiting Criteria (DILC).

1 Any WHO grade 3 or 4 non-hematological toxicity

2 Neutropenia grade 4: neutrophil count $<500 / \mu$ l for a period of more than 7 days

3 Febrile neutropenia: neutrophil count $<500 / \mu \mathrm{l}$ and fever

4 Thrombocytopenia grade 4: platelet count $<25.000 /$ ul for more than 4 days

5 Delay of chemotherapy due to incomplete recovery on the day of scheduled therapy: Hematological: neutrophil count $<2.000 / \mu \mathrm{l}$ and/or platelet count $<100.000 / \mu \mathrm{l}$ Persistence of non-hematological side effects of WHO grade 2 or more (excluding alopecia and anticipatory nausea and vomiting)

6 Cardiotoxicity, defined by development of clinical cardiac failure or an absolute decrease in MUGA LVEF either $\geq 20 \%$ (EF absolute units) from baseline to a value above $50 \%$ or $\geq 10 \%$ (EF absolute units) to a value below $50 \%$

\section{Pretreatment and follow-up evaluation}

All patients were initially evaluated with a history, physical examination, complete blood cell count, liver and kidney function tests, ECG and LVEF MUGA scan, chest x-ray and bone scan. If indicated, $x$-ray studies of selected osseous segments, ultrasound and/or computer tomography scans of suspected areas, with tumor measurements (if possible) was performed. Complete blood cell count was repeated twice weekly and a biochemical profile was assessed before each cycle. Follow-up LVEF MUGA scan was requested after each three cycles, in case of clinical signs of congestive heart failure, if patients went off study or at a cumulative dose of $500 \mathrm{mg} / \mathrm{m}^{2}$ epirubicin, at $800 \mathrm{mg} / \mathrm{m}^{2}$ and subsequently before each additional treatment course thereafter. In our study cardiac toxicity was defined as development of clinical cardiac failure and/or an absolute decrease in resting LVEF either $\geq 20 \%$ (EF absolute units) from baseline to a value above $50 \%$ or $\geq 10 \%$ to a value below $50 \%$.

Tumor evaluation was repeated after each three cycles, at the end of treatment or as clinically indicated and evaluated according to UICC-criteria. ${ }^{15}$ Toxicity was assessed after each course according to WHO grading criteria $^{15}$ except for neutropenia, 
thrombocytopenia, febrile neutropenia and cardiotoxicity for which adjusted criteria were applied (see Table 3.1).

\section{Results}

\section{Patient Characteristics}

Forty-one eligible patients were entered, and five patients were found to be not evaluable. In the 8-day interval four patients (protocol violations after cycle 1 [two patients] and central venous line complications [two patients]) and in the 10-day interval with paclitaxel $175 \mathrm{mg} / \mathrm{m}^{2}$ one patient (too low G-CSF dose). Therefore, 36 patients were fully assessable for the present report. The characteristics of these 36 patients are shown in Table 3.2. These 36 patients received 131 cycles according to the protocol until DILC or protocol completion. An additional 71 cycles were administered off protocol with longer intervals in 21 patients.

Table 3.2 Patient characteristics.

\begin{tabular}{lc}
\hline Eligible/evaluable & 36 \\
Median age (range) & $51(24-68)$ \\
Performance ECOG 0/1/2 & $14 / 18 / 4$ \\
Adjuvant chemotherapy & 14 \\
$\quad$ Including anthracyclines & 5 \\
Previous chest/breast irradiation & 28 \\
Sites of disease in patients (\% of all patients) & \\
$\quad$ Bone & $64 \%$ \\
Soft tissue & $81 \%$ \\
$\quad$ Lung & $36 \%$ \\
$\quad$ Liver & $47 \%$ \\
$\quad$ Lung and/or liver & $61 \%$ \\
No. of organs involved & \\
$\quad$ Median (range) & $2(1-5)$ \\
\hline
\end{tabular}

\section{Initial dose-intensity limiting criteria (DILC's) in the first three consecutive cycles}

In this study analyzing shortening of intervals with fixed doses of epirubicin and paclitaxel $75 / 135 \mathrm{mg} / \mathrm{m}^{2}$, six patients were entered at the starting interval of 14 days. One patient encountered a DILC: an incomplete platelet recovery was observed at scheduled cycle 2 (Table 3.3). At the 12-day interval one out of eight patients met a DILC: after the third cycle this patient developed nausea/vomitus WHO grade 3 . In the 10 days interval one out of 10 patients had a DILC: after the third cycle an incomplete neutrophil recovery was observed. At the eight-day interval four out of six patients met a DILC during the first three cycles, making this interval not feasible based on the 
predefined criteria. The initial DILC's were: incomplete neutrophil recovery at scheduled cycle 2 in three patients and combined febrile neutropenia and mucositis WHO grade 3 after cycle 2 in the fourth patient. Ten days was the shortest feasible interval for epirubicin/paclitaxel $75 / 135 \mathrm{mg} / \mathrm{m}^{2}$ with G-CSF and the median DDI for the first three cycles was 52 (range 49-56) $\mathrm{mg} / \mathrm{m}^{2} /$ week and 94 (range 88-100) $\mathrm{mg} / \mathrm{m}^{2} /$ week, respectively.

To investigate whether in the 10 days interval the dose of paclitaxel could be increased, epirubicin/paclitaxel $75 / 175 \mathrm{mg} / \mathrm{m}^{2}$ was tested in this 10 days interval. Two out of six patients encountered a DILC, transient asymptomatic pathologic decrease in cardiac LVEF after the third course, and infection (pneumonia) grade 2 at scheduled cycle four, respectively. The median DDI in the first three cycles was epirubicin 52 (52-53) $\mathrm{mg} / \mathrm{m}^{2} /$ week and paclitaxel $123(117-126) \mathrm{mg} / \mathrm{m}^{2} /$ week.

Table 3.3 Epirubicin/Paclitaxel + G-CSF; Initial Dose-intensity Limiting Criteria (DILC's) in the first three cycles

\begin{tabular}{lccccc}
\hline Dose EP mg/m-2 & $75 / 135$ & $75 / 135$ & $75 / 135$ & $75 / 135$ & $75 / 175$ \\
Interval days & 14 & 12 & 10 & 8 & 10 \\
\hline Evaluable patients & 6 & 8 & 10 & 6 & 6 \\
Patient(s) with DILC & 1 & 1 & 1 & 4 & 2 \\
DILC & & & & 3 & \\
ANC-recovery & 1 & & & $1^{\text {a }}$ & \\
Platelet-recovery & & & & $1^{\text {a }}$ & \\
Febrile neutropenia & & 1 & & \\
Mucositis grade $\geq 3$ & 1 & & & & 1 \\
$\quad \begin{array}{l}\text { Nausea/vomitus grade } \geq 3 \\
\text { Infection }\end{array}$ & & & & \\
Cardiotoxicity & & & & \\
\hline
\end{tabular}

${ }^{a}$ One patient with concurrent febrile neutropenia and mucositis grade 3 after cycle 2 .

\section{Cumulative toxicity}

In the 14-day interval all five patients without a DILC in the first three cycles continued at their scheduled interval for at least six cycles. In the 12-day interval seven out of eight patients continued the same chemotherapy combination after three protocol cycles, although only two patients at scheduled interval for a total of four cycles, all without additional toxicities.

In the 10 day interval three out of ten patients continued scheduled treatment for a total of four (two patients) and nine (one patient) cycles, respectively. However the latter needed delay of cycle seven for five days because of an intercurrent periodontal infection and subsequently continued scheduled treatment. The single patient with an incomplete neutrophil recovery after cycle three, encountered again an incomplete neutrophil and platelet recovery after cycle four and five, and developed a reversible peripheral neuropathy grade 3 after cycle six. In the 8 day interval the two patients 
without a DILC in the initial three cycles continued the scheduled interval for a total of five (stomatitis and infectious tonsillitis grade 3 ) and six cycles, respectively. The three patients with an initial incomplete neutrophil recovery, encountered the same DILC in additional cycles. The patient with a febrile neutropenia and stomatitis grade 3 after the second cycle in addition developed pulmonary embolism, and stopped protocol chemotherapy. In the 10 days interval epirubicin/paclitaxel $75 / 175 \mathrm{mg} / \mathrm{m}^{2}$ only one patient continued scheduled treatment for 6 cycles. The kinetics of neutrophil and platelet counts for the patients in the various intervals are shown in Figure 3.1. The non-hematological toxicities were generally mild and are displayed in Table 3.4. One patient encountered a hypersensitivity reaction WHO grade 2 .

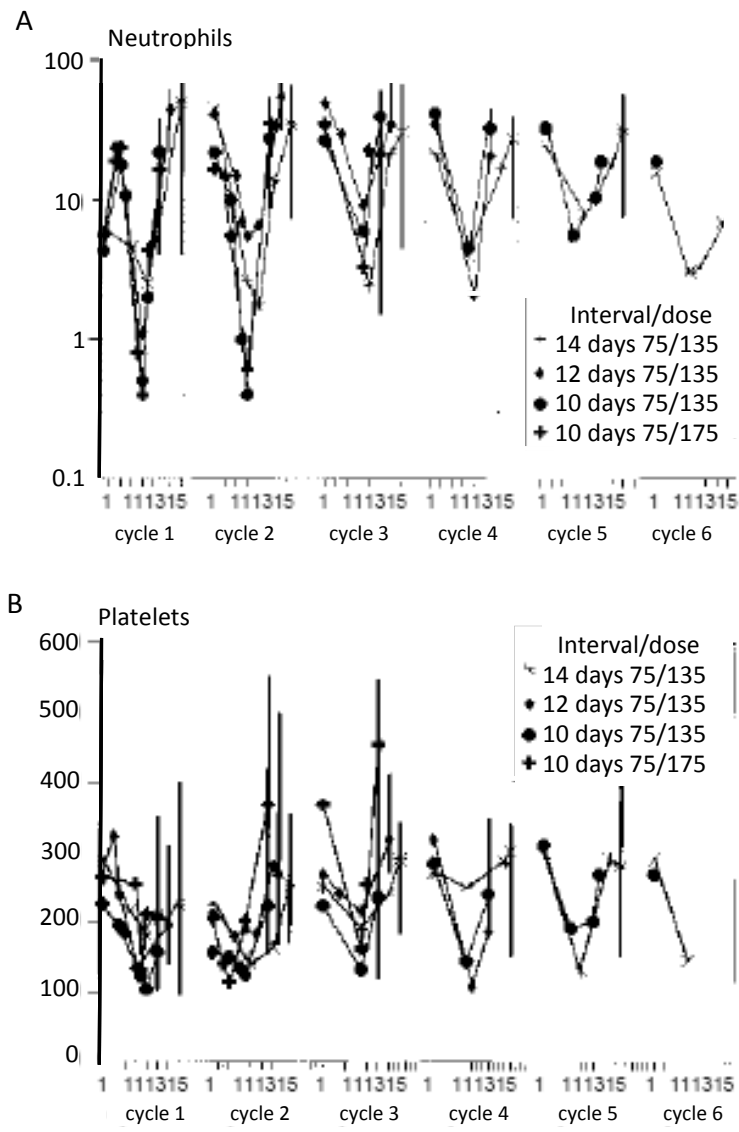

Figure 3.1 Interval shortening of epirubicin and paclitaxel plus G-CSF. Median values per day and range of values at the day of next scheduled cycle, of consecutive chemotherapy cycles according to protocol: (A) neutrophils (x 1000/ $\mu \mathrm{l})$, (B) platelets $(\times 1000 / \mu \mathrm{l})$. 
Table 3.4 Number of patients (percentage) encountering non-hematological toxicities (WHO-grading) for all cycles with epirubicin and paclitaxel with G-CSF support.

\begin{tabular}{lclllllc}
\hline $\begin{array}{l}\text { WHO } \\
\text { grading }\end{array}$ & $\begin{array}{l}\text { Nausea/ } \\
\text { Vomitus }\end{array}$ & Diarrhea & Stomatitis & Neurotoxicity & Myalgia & Infection & Skin \\
\hline 1 & $12(32 \%)$ & $3(8 \%)$ & $8(22 \%)$ & $9(24 \%)$ & $10(27 \%)$ & 0 & 0 \\
2 & $12(32 \%)$ & $5(14 \%)$ & $8(22 \%)$ & $3(8 \%)$ & $7(19 \%)$ & $2(5 \%)$ & $3(8 \%)$ \\
3 & $1(3 \%)$ & 0 & $3(8 \%)$ & $1(3 \%)$ & $1(3 \%)$ & $2(5 \%)$ & 0 \\
4 & 0 & 0 & 0 & 0 & 0 & 0 & 0 \\
\hline
\end{tabular}

\section{Transfusion of bloodproducts}

In this dose dense schedule during the first 3 cycles red blood cell (RBC) transfusions were needed in five patients. Most transfusions occurred in the patients receiving more than three cycles (14 out 27 patients). Platelet transfusions were not given.

\section{Cardiotoxicity}

A total of 98 MUGA scans were performed; basal and follow-up scans were available in 35 of 36 patients, making them evaluable for cardiotoxicity by ejection fraction. A pathological decline in LVEF, as defined earlier, was observed in two (6\%) patients after the first three cycles, all without previous anthracycline containing adjuvant chemotherapy. In the 14-day interval the patient with a delayed platelet recovery after the first cycle, received cycle two after platelet recovery, which was complicated by severe dyspnea and anemia, with a transient decrease in LVEF (63\% $\rightarrow 49 \%)$. On physical examination, chest X-ray and ECG no signs of congestive heart failure were observed. After RBC transfusion patient recovered and a control LVEF showed normalization (62\%). This patient continued scheduled treatment for an additional three cycles, without further signs of cardiac failure. A short interval (one day) between the end of radiotherapy on the lumbar spine and start of study treatment may explain these transient DILC's. In the second patient (10 day interval EP $\left.75 / 175 \mathrm{mg} / \mathrm{m}^{2}\right)$ after 3 cycles an asymptomatic change in LVEF $(60 \% \rightarrow 49 \%)$ was observed. Patient continued with three cycles of epirubicin/cyclophosphamide (EC) with follow-up LVEF's of 53\% (after first EC), 59\% (after third EC) and 65\% (three months after third $\mathrm{EC}$ ), respectively. From 20 patients cardiac evaluation is available with a cumulative epirubicin dose of $\geq 450 \mathrm{mg} / \mathrm{m}^{2}$; median baseline LVEF $60 \%$ (range $50 \%-72 \%$ ) $\rightarrow 58 \%$ (range 30\%-77\%). One patient in the 14 days interval continued, after 6 protocol cycles, the same regimen with a 21 days interval and developed congestive heart failure with a LVEF of $30 \%$ after cycle 13 (cumulative dose epirubicin $975 \mathrm{mg} / \mathrm{m}^{2}$ ). The single patient with a DILC in the 10 day interval at a dose of $75 / 135 \mathrm{mg} / \mathrm{m}^{2}$, developed symptomatic ventricular extrasystoles after cycle 3 , without a decrease in LVEF, and continued treatment for a total of 6 cycles. 


\section{Response rate}

Although efficacy was not an aim of this study, formal UICC criteria were applied to the 29 patients with measurable disease. After three cycles, i.e. evaluation 20-42 days after the start of the study treatment, already an objective response (all partial) was observed in 17 out of 29 patients (55\%, 95\% Cl 41-77\%), and there were no patients with progressive disease. Nineteen patients (stable disease 11, partial response 6 and 1 mixed response) continued protocol treatment with an interval of $\leq 14$ days for a median number of six cycles (range 4-9) whereby six additional patients reached a partial response and two partial responders reached a complete remission. The median interval between the start of therapy and the first observation of an objective clinical response was five weeks (range 3-12 weeks). The best response for the total study group was $79 \%$ (95\% Cl 65-94\%).

\section{Discussion}

The aim of our study was to determine the maximal dose intensity of epirubicin in combination with paclitaxel in a dose dense schedule, supported by G-CSF. With a regimen consisting of epirubicin $75 \mathrm{mg} / \mathrm{m}^{2}$ and paclitaxel $135 \mathrm{mg} / \mathrm{m}^{2}$ an interval of 10 days was feasible, allowing a median DDI of $52 \mathrm{mg} / \mathrm{m}^{2} /$ week for epirubicin and $94 \mathrm{mg} / \mathrm{m}^{2} /$ week for paclitaxel, respectively. In the 10 day interval it was feasible to increase the paclitaxel dose to $175 \mathrm{mg} / \mathrm{m}^{2}$ enabling a median DDI of $123 \mathrm{mg} / \mathrm{m}^{2} /$ week for paclitaxel in combination with $52 \mathrm{mg} / \mathrm{m}^{2} /$ week of epirubicin. The treatmentschedule related toxicity was relatively mild. Nine out 36 patients developed a DILC in the first 3 cycles. Initial DILC's were incomplete hematological recovery at the day of scheduled cycle in five, febrile neutropenia in one and non-hematological in the remaining three patients, respectively.

An important aspect of studies on escalated dose intensities is whether this can be maintained over repeated cycles. Conceivably with intervals as short as 10 days and retreatment at the moment of rapid recovery, the population of progenitor cells may be vulnerable to the repetitive cytotoxic insults and may become exhausted after a number of cycles. Although most data were collected over 3 cycles, we have not observed signs of exhaustion, also not in the small number of patients treated up to six cycles. It may well be treatment with G-CSF up to the day before the next chemotherapy has protected progenitor cells by putting them out of cycles as has been observed with GM-CSF. ${ }^{16}$ In a study of the epirubicin-paclitaxel combination in a 21 days interval without G-CSF the neutrophil-nadir occurs at day 12 and the median neutropenia grade 4 duration was 3 days. ${ }^{17}$ In our study, with G-CSF, the neutrophilnadir was reached earlier, at day 8 , was of very short duration, and was less pronounced in each consecutive cycle. G-CSF administered on all days, with the exception of the day of chemotherapy, fastened the neutrophil recovery after each 
chemotherapy course, but may also have had a pre-emptive effect on each consecutive cycle by expansion of the progenitor pool. However, this so-called preemptive G-CSF effect was not observed earlier. ${ }^{18}$ Thrombocytopenia has not been dose limiting. Further data on larger numbers of patients with even more cycles are needed to determine the absence of cumulative myelosuppression with certainty.

The MTD of the epirubicin and paclitaxel (3-hour) combination in a 21 days schedule without "prophylactic" hematopoietic growth factor as first line treatment in metastatic breast cancer has been investigated. The several MTD's of this combination were $50 / 250 \mathrm{mg} / \mathrm{m}^{2}, 60 / 175 \mathrm{mg} / \mathrm{m}^{2}, 90 / 175 \mathrm{mg} / \mathrm{m}^{2}$ and 90/200 mg/m , respectively. Dose limiting toxicities were primarily hematologic: severe neutropenia and febrile neutropenia. ${ }^{19-21}$ The DDI in the latter study is $30 \mathrm{mg} / \mathrm{m}^{2} /$ week for epirubicin and $67 \mathrm{mg} / \mathrm{m}^{2} /$ week for paclitaxel, which is considerable lower than our results of 52 and $122 \mathrm{mg} / \mathrm{m}^{2} /$ week, respectively. In these three studies the objective response rates after at least 6 cycles were 44\%, 68\% (CR in 17\%) and 84\% (CR in 18\%), respectively. ${ }^{19-21}$ These data suggest a dose-response relationship for epirubicin. In our study after three short interval cycles already a response rate of $53 \%$ was observed.

The combination of paclitaxel (3-hrs) and bolus doxorubicin was very effective (83-95\% overall response rate, $24-41 \%$ complete responses) in two single-center phase I/II studies with chemotherapy-naive patients. ${ }^{10,11}$ Six combination chemotherapy cycles were apparently sufficient to achieve at least a partial response (CR $15 \%$ ) in all responding patients. Continuous treatment with single-agent paclitaxel, significantly contributed to the final complete response rate of $41 \%$. $^{22}$ The difference in response rates between the epirubicin and doxorubicin studies may be explained by the considerable higher percentage of adjuvant chemotherapy pretreated patients in the epirubicin/paclitaxel combination studies. A recent multicenter randomized phase III study with doxorubicin $50 \mathrm{mg} / \mathrm{m}^{2}$ (bolus iv) and paclitaxel $150 \mathrm{mg} / \mathrm{m}^{2}$ (24-hours), reported a response rate of only $46 \% .^{23}$

An important argument to investigate epirubicin in combination with paclitaxel, is to circumvent the increased cardiotoxicity of the doxorubicin/paclitaxel combination; after a median cumulative doxorubicin dose of $480 \mathrm{mg} / \mathrm{m}^{2}, 50 \%$ of the patients had reductions of the cardiac left ventricular ejection fraction (LVEF) below the norm and $20 \%$ of the patients developed a congestive heart failure. ${ }^{10,11}$ To prevent this excess in cardiotoxicity, the cumulative dose of doxorubicin in this combination needs to be limited to $360 \mathrm{mg} / \mathrm{m}^{2}$, which makes this regimen not applicable in doxorubicin adjuvant pretreated patients. ${ }^{24}$ In the epirubicin/paclitaxel combination studies cardiac toxicity was observed in $13 \%$ (all anthracycline pretreated), $1 \%$ and $8 \%$ of the patients, respectively. ${ }^{19-21}$ In the latter study a minimal median LVEF decrease $(58 \% \rightarrow 56 \%)$ was observed after a cumulative epirubicin dose of $>900 \mathrm{mg} / \mathrm{m}^{2}{ }^{21}$ These data suggest less cardiotoxicity for the epirubicin/paclitaxel combination.

Norton has shown that a Gompertzian growth model precisely fitted in the growth curves of breast cancer. ${ }^{24}$ In this model, when a patient with advanced breast cancer is treated, the tumor mass is large, its growth fraction is low and the fraction of cells 
killed is low. Shortening of intervals with effective dose combination chemotherapy (dose dense) may be important to overcome the cytokinetic resistance of tumors, by killing chemosensitive cells and recruiting regrowth of dormant cells, which will be killed by the subsequent cycle. Therefore on theoretical grounds, treatment of advanced breast cancer may start with short repetitive cycles of effective dose (dosedense) chemotherapy, followed by increased dose size (dose-escalated) chemotherapy.

In conclusion, with the addition of G-CSF, shortening of intervals of chemotherapy seems to be an effective method of dose intensification, allowing a dose intensity of $52 \mathrm{mg} / \mathrm{m}^{2} /$ week of epirubicin in combination with $122 \mathrm{mg} / \mathrm{m}^{2} /$ week of paclitaxel. The efficacy and clinical relevance of this approach, is investigated now in a phase II study. 


\section{References}

1. Holmes FA, Walters RS, Theriault RL, Forman AD, Newton LK, Raber MN, Buzdar AU, Frye DK, Hortobagyi GN. Phase II trial of Taxol, an active drug in the treatment of metastatic breast cancer. J Natl Cancer Inst 1991;83:1797-1805.

2. Reichman BS, Seidman AD, Crown JPA, Heelan R, Hakes TB, Lebwohl DE, Gilewski TA, Surbone A, Currie $V$, Hudis CA, et al. Paclitaxel and Recombinant human granulocyte colony-stimulating factor as initial chemotherapy for metastatic breast cancer. J Clin Oncol 1993;11:1943-1951.

3. Eisenhauer EA, ten Bokkel Huinink WW, Swenerton KD, Gianni L, Myles J, van der Burg ME, Kerr I, Vermorken JB, Buser K, Colombo N, et al. European-Canadian randomized trial of paclitaxel in relapsed ovarian cancer: High-dose versus low-dose and long versus short infusion. J Clin Oncol 1994; 12:2654-2666.

4. Nabholtz JM, Gelmon K, Bontenbal M, Spielmann M, Catimel G, Conte P, Klaassen U, Namer M, Bonneterre J, Fumoleau P, Winograd B. Multicenter, randomized comparative study of two doses of paclitaxel in patients with metastatic breast cancer. J Clin Oncol 1996;14:1858-1867.

5. Gianni L, Munzone E, Capri G, Villani F, Spreafico C, Tarenzi E, Fulfaro F, Caraceni A, Martini C, Laffranchi A, et al. Paclitaxel in metastatic breast cancer: A trial of two doses by a 3-hour infusion in patients with disease recurrence after prior therapy with anthracyclines. J Natl Cancer Institute 1995; 87:1169-1175.

6. Gianni L. Theoretical and practical aspects of paclitaxel scheduling. Ann Oncol 1995;6:861-863.

7. Fisherman JS, McCabe M, Noone M, Ognibene FP, Goldspiel B, Venzon DJ, Cowan KH, O'Shaughnessy JA. Phase I study of Taxol, Doxorubicin plus granulocyte colony stimulating factor (G-CSF) in patients, with metastatic breast cancer. Monogr Natl Cancer Inst 1993;15:189-194.

8. Holmes FA, Frye D, Valero V, et al. Phase I study of taxol (T) and doxorubicin (D) with G-CSF in patients patients (PTS) without prior chemotherapy (CT) for metastatic breast cancer (MBC). Proc Am Soc Clin Oncol 1992;11:60 (Abstr).

9. Sledge GW Jr, Robert M, Sparano JA, et al. Paclitaxel (Taxol)/doxorubicin combinations in advanced breast cancer: The Eastern Cooperative Oncology Group experience. Semin Oncol 1994;21(Suppl 8):15-18.

10. Gianni L, Munzone E, Capri G, Fulfaro F, Tarenzi E, Villani F, Spreafico C, Laffranchi A, Caraceni A, Martini $C$, et al. Paclitaxel by 3-hour infusion in combination with bolus doxorubicin in women with untreated metastatic breast cancer: High antitumor efficacy and cardiac effects in a dose-finding and sequence- finding study. J Clin Oncol 1995;13:2688-2699.

11. Gehl J, Boesgaard M, Paaske T, Vittrup Jensen B, Dombernowsky P. Combined doxorubicin and paclitaxel in advanced breast cancer: Effective and cardiotoxic. Ann Oncol 1996;7:678-693.

12. Jain KK, Casper ES, Geller NL, Hakes TB, Kaufman RJ, Currie V, Schwartz W, Cassidy C, Petroni GR, Young $\mathrm{CW}$, et al. A prospective randomized comparison of epirubicin and doxorubicin in patients with advanced breast cancer. J Clin Oncol 1985; 3: 818-826.

13. Henderson IC, Hayes DF, Gelman R. Dose-response in the treatment of breast cancer. J Clin Oncol 1988;6:1501-1516.

14. Lalisang RI, Wils JA, Nortier HW, Burghouts JT, Hupperets PS, Erdkamp FL, Schouten HC, Blijham GH. A comparative study of dose escalation versus interval reduction to obtain dose intensification of epirubicin and cyclophosphamide with G-CSF for patients with metastatic breast cancer. J Clin Oncol 1997;15:1367-1376.

15. Miller AB, Hoogstraten B, Staquet M, Winkler A. Reporting results of cancer treatment. Cancer 1981; 47:207-214.

16. Vadhan-Raj S, Broxmeyer HE, Hittelman WN, Papadopoulos NE, Chawla SP, Fenoglio C, Cooper S, Buescher ES, Frenck RW Jr, Holian A, et al. Abrogating chemotherapy-induced myelosuppression by recombinant granulocyte-macrophage colony-stimulating factor in patients with sarcoma: Protection at the progenitor cell level. J Clin Oncol 1992;10:1266-1277.

17. Conte PF, Michelotti A, Baldini E, Tibaldi C, DaPrato M, Salvadori B, Giannessi PG, Gentile A, Biadi O, Mariani M. Activity and safety of epirubicin plus paclitaxel in advanced breast cancer. Semin Oncol 1996;23(1Suppl 1): 28-32. 
18. de Wit R, Verweij J, Bontenbal M, Kruit WH, Seynaeve C, Schmitz PI, Stoter G. Adverse effect on bone marrow protection of prechemotherapy granulocyte colony-stimulating factor support. J Natl Cancer Inst 1996;88:1393-1398.

19. Catimel G, Spielmann M, Dieras V, Kayitalire L, Pouillart P, Guastalla JP, Soler-Michel P, Graffand N, Garet F, Dumortier A, Pellae-Cosset B, Chazard M. Phase I study of paclitaxel and epirubicin in patients with metastatic breast cancer: A preliminary report on safety. Semin Oncol 1996; 23(Suppl 1): $24-27$.

20. Lück HJ, Thomssen C, du Bois A, Untch M, Lisboa B, Köhler G, Diergarten K. Phase II study of paclitaxel and epirubicin as first-line therapy in patients with metastatic breast cancer. Semin Oncol 1997;24: 35-39 (Suppl 17).

21. Conte PF, Baldini E, Gennari A, Michelotti A, Salvadori B, Tibaldi C, Danesi R, Innocenti F, Gentile A, Dell'Anna R, Biadi O, Mariani M, Del Tacca M. Dose-finding study and pharmacokinetics of epirubicin and paclitaxel over 3 hours: A regimen with high activity and low cardiotoxicity in advanced breast cancer. J Clin Oncol 1997; 15: 2510-2517.

22. Gianni L, Capri G. Experience at the Instituto Nazionale Tumori with paclitaxel in combination with doxorubicin in women with untreated breast cancer. Semin Oncol 1997; 24: 1-3 (Suppl 3).

23. Sledge Jr GW, Neuberg D, Ingle J, et al. Phase III trial of doxorubicin vs. paclitaxel vs. doxorubicin + paclitaxel as first-line therapy for metastatic breast cancer: an intergroup trial. Proc Am Soc Clin Oncol 1997; 16: 1 (Abstr).

24. Hortobagyi GN, Willey J, Rahman Z, Holmes FA, Theriault RL, Buzdar AU. Prospective assessment of cardiac toxicity during a randomized phase II trial of doxorubicin and paclitaxel in metastatic breast cancer. Sem Oncol 1997; 24: 65-68 (Suppl 17).

25. Norton LA. A Gompertzian model of human breast cancer growth. Cancer Res 1988; 48: 7067-7077. 


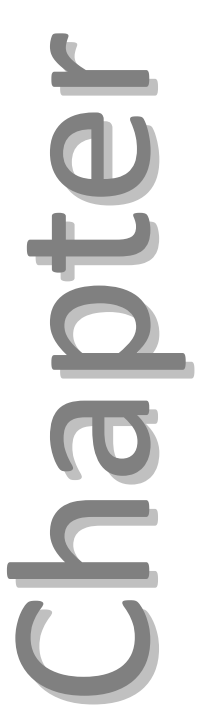

\section{Epirubicin and paclitaxel with G-CSF} support in first line metastatic breast cancer: A randomized phase II study of dose-dense and dose-escalated chemotherapy

Lalisang RI, Erdkamp FLG, Rodenburg CJ, Knibbeler-van Rossum CTAM, Nortier JWR, van Bochove A, Slee PHThJ, Voest EE, Wils JA, Wals J, Loosveld OJL, Smals AEM, Blijham GH, Tjan-Heijnen VCG ${ }^{\circledR}$, Schouten $\mathrm{HC}^{@}$

${ }^{\circledR}$ Both authors contributed equally to this work. 


\section{Abstract}

\section{Background}

An increased dose-intensity can be achieved by either higher dose of chemotherapy per cycle (doseescalation) or by shortening the interval between cycles (dose-dense).

\section{Design}

This multicentre randomized phase II study assessed the efficacy and safety of two different approaches: epirubicin $110 \mathrm{mg} / \mathrm{m}^{2}$ combined with paclitaxel $200 \mathrm{mg} / \mathrm{m}^{2}$ every 21 days and epirubicin $75 \mathrm{mg} / \mathrm{m}^{2}$ combined with paclitaxel $175 \mathrm{mg} / \mathrm{m}^{2}$ every 10 days, both supported with G-CSF. Patients with advanced breast cancer and without prior palliative chemotherapy were scheduled for 6 cycles.

\section{Results}

101 patients were evaluable for response and 106 patients for toxicity. Grade $\geq 3$ toxicities occurred in $39 \%$ of patients in the dose-escalated arm and in $29 \%$ of the dose-dense arm, mainly febrile neutropenia, thrombocytopenia, neurotoxicity and (asymptomatic) cardiotoxicity. The median delivered cumulative doses for epirubicin/paclitaxel were $656 / 1194 \mathrm{mg} / \mathrm{m}^{2}$ and $448 / 1045 \mathrm{mg} / \mathrm{m}^{2}$, treatment durations were 126 and 61 days, and delivered dose intensities were $36 / 67 \mathrm{mg} / \mathrm{m}^{2} /$ week and $51 / 120 \mathrm{mg} / \mathrm{m}^{2} /$ week for the dose-escalated en dose-dense arm, respectively. Response rates were $75 \%$ and $70 \%$, the progression-free survival 6 and 7 months, respectively.

\section{Conclusion}

Dose-dense chemotherapy with a lower cumulative dose, a halved treatment time, but a higher doseintensity may be as effective and safe as dose-escalated chemotherapy. The value of dose-densification over standard scheduled chemotherapy regimes yet needs to be determined. 


\section{Introduction}

In advanced breast cancer anthracycline non-taxane combination regimens as firstline systemic therapy results in a $30-50 \%$ overall response rate, a complete response rate of $5-10 \%$, and a median progression-free survival of 4-8 months. ${ }^{1}$ The combination of paclitaxel and doxorubicin showed promising response rates of 83 $95 \%$ in clinical phase I and II studies. ${ }^{2,3}$ The superiority of an anthracycline-taxane combination was subsequently confirmed in five randomized phase III studies with response rates of $55-68 \%$ and a (small) gain in progression-free survival. ${ }^{4-8}$ Two studies showed a significant improvement in overall survival, but at the cost of considerable increase in treatment related toxicity, mainly febrile neutropenia, infections and cardiac toxicity.

Epirubicin is a synthetic doxorubicin analogue, with a similar activity but decreased toxicity profile, in particular less cardiotoxicity. ${ }^{9}$ The addition of G-CSF may reduce the incidence of febrile neutropenia, but also increases the dose-intensity of cytotoxic agents. This can be accomplished by reducing the interval between the administrations of "standard doses" of chemotherapy or by increasing the dose with a "standard inter-cyclic interval". These two approaches of dose-intensification have also been called "dose-densification" and "dose-escalation", respectively. However, the biological effect and clinical relevance of these approaches may be quite different. Dose-densification of chemotherapy may be important to kill chemo sensitive tumor cells, by preventing early regrowth of dormant cells. The major effect of doseescalation may be a more effective eradication of resistant tumor cells and the dose size may also be the most important factor in reducing the risk of developing resistant cells. $^{10,11}$

Our group initially investigated both approaches with epirubicin/cyclophosphamide combination chemotherapy supported by G-CSF, in the treatment of advanced breast cancer. We concluded that dose-densification allowed a higher dose-intensity than dose-escalation. ${ }^{12}$ Based on these results we next determined the maximal doseintensity of the epirubicin/paclitaxel combination supported with G-CSF. In the dosedense approach the intercyclic interval of epirubicin $75 \mathrm{mg} / \mathrm{m}^{2}$ and paclitaxel $135 \mathrm{mg} / \mathrm{m}^{2}$ could be reduced to 10 days. In this 10 days interval it was feasible to increase the paclitaxel dose up to $175 \mathrm{mg} / \mathrm{m}^{2}$, enabling a dose intensity of $52 \mathrm{mg} / \mathrm{m}^{2} /$ week for epirubicin and $122 \mathrm{mg} / \mathrm{m}^{2} /$ week for paclitaxel, respectively. ${ }^{13}$ In the dose-escalation approach the maximal tolerated doses of a 3-weekly schedule was $110 \mathrm{mg} / \mathrm{m}^{2}$ for epirubicin and $240 \mathrm{mg} / \mathrm{m}^{2}$ for paclitaxel (unpublished data). The doseintensity of this latter schedule is 37 and $80 \mathrm{mg} / \mathrm{m}^{2} /$ week, respectively.

The current randomized phase II study evaluates the efficacy and tolerability of the two dose-intensified chemotherapy regimens consisting of epirubicin and paclitaxel, supported with G-CSF. The main objective of the study was to test whether a high response rate (overall response rate $\geq 80 \%$ ) could be achieved. Secondary objectives 
were to assess the progression-free interval, and evaluate the safety profiles and cardiotoxicity.

\section{Materials and methods}

\section{Patient selection}

The inclusion criteria for women with advanced breast cancer were: measurable and histological proven breast cancer; age 18 to 70 years; performance status 0 to 2 (Eastern Cooperative Oncology Group [ECOG] scale); adequate hematological, hepatic and renal function; no prior chemotherapy for metastatic disease; prior adjuvant chemotherapy allowed, if interval after last chemotherapy cycle $\geq 1$ year and at entry cumulative dose of doxorubicin $\leq 300 \mathrm{mg} / \mathrm{m}^{2}$ or epirubicin $\leq 450 \mathrm{mg} / \mathrm{m}^{2}$; normal left ventricular ejection fraction (LVEF) assessed using multigated acquisition (MUGA) scan and without symptomatic cardiovascular disease. Exclusion criteria were central nervous system involvement, history of other malignancy, active infectious disease and pre-existing neuropathy.

\section{Study design}

This open-label multi-centre randomized phase II trial was approved by the institutional review boards of the 12 participating hospitals, and the procedures followed were in accordance with the Helsinki Declaration 1996 of the World Medical Association. Randomization was independently centrally performed, and patients were stratified according to participating centre and prior adjuvant anthracycline containing chemotherapy (yes/no).

Pre-study evaluation included history, physical and blood examination, chest x-ray, liver ultrasound, skeletal scintigraphy, ECG and cardiac MUGA-scan. Suspected lesions were assessed by the best evaluable and reproducible (radiological) technique. Full blood count was weekly repeated and routine biochemistry was assessed before each cycle. Assessment of LVEF was scheduled at baseline, after treatment cycles three and six, before each additional treatment cycle after a cumulative dose of $800 \mathrm{mg} / \mathrm{m}^{2}$ epirubicin, in case of clinical signs of cardiac failure, if patients went off study, and three months after the last chemotherapy cycle.

In this study the epirubicin (Pfizer Inc., New York, NY) was given as a short intravenous infusion, followed by paclitaxel $\left(\right.$ Taxol $^{\circledR}$, Bristol-Myers Squibb, New York, NY) as a three-hours infusion. A routine premedication regime was adopted to prevent hypersensitivity reactions and nausea/vomiting. Concomitant endocrine, erythropoietin or prophylactic antibiotic therapy was not allowed. Patients were transfused when necessary to maintain a platelet count of $\geq 15,000 / \mu \mathrm{l}$ and hemoglobin level $\geq 8.0 \mathrm{~g} / \mathrm{dl}$. 
Dose-intensity is defined as the chemotherapy dose per unit time and was expressed as $\mathrm{mg} / \mathrm{m}^{2} /$ week. The cumulative dose is the product of dose per cycle and number of cycles of chemotherapy.

In the dose-escalated arm initially epirubicin $110 \mathrm{mg} / \mathrm{m}^{2}$ and paclitaxel $240 \mathrm{mg} / \mathrm{m}^{2}$ was given both on day 1, q 21 days, with R-metHuG-CSF (Filgrastim ${ }^{\circledR}$, Amgen Inc. Thousands Oaks, CA) $5 \mu \mathrm{gr} / \mathrm{kg}$ subcutaneously on days 2-14, for six cycles. However due to an excess of serious adverse events in four out of the first nine patients, the paclitaxel dose was reduced to $200 \mathrm{mg} / \mathrm{m}^{2}$ (see results). The new scheduled cumulative doses for epirubicin was $660 \mathrm{mg} / \mathrm{m}^{2}$ and for paclitaxel $1200 \mathrm{mg} / \mathrm{m}^{2}$, and the dose-intensity was 37 and $67 \mathrm{mg} / \mathrm{m}^{2} /$ week, respectively.

The dose-dense schedule consisted of epirubicin $75 \mathrm{mg} / \mathrm{m}^{2}$ and paclitaxel $175 \mathrm{mg} / \mathrm{m}^{2}$ both on day 1 with a 10 days interval, with G-CSF support on days 2-10, for six cycles. The scheduled cumulative doses were for epirubicin $450 \mathrm{mg} / \mathrm{m}^{2}$ and paclitaxel $1050 \mathrm{mg} / \mathrm{m}^{2}$. The scheduled dose-intensity was $52 \mathrm{mg} / \mathrm{m}^{2} /$ week and $122 \mathrm{mg} / \mathrm{m}^{2}$ / week. (Figure 4.1)
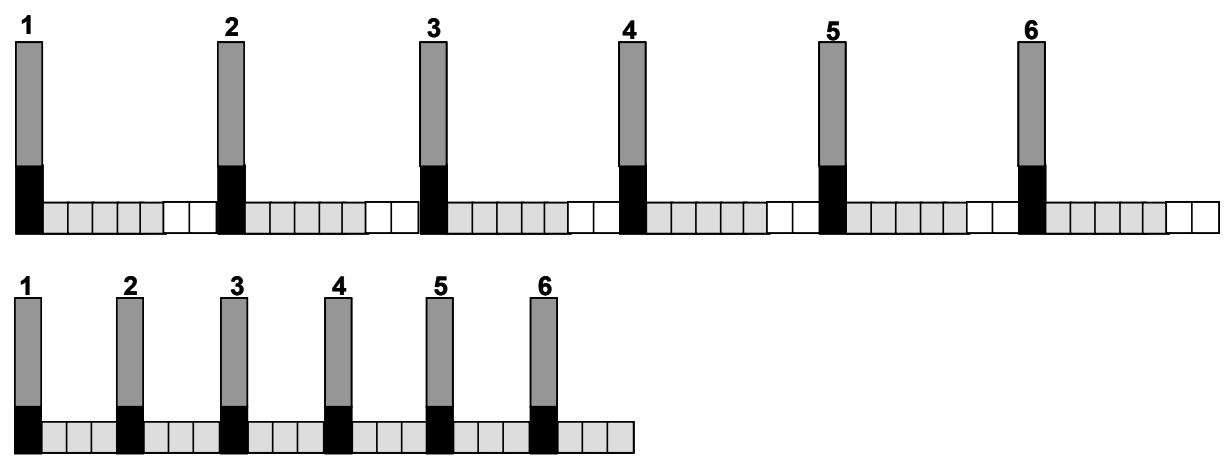

Figure 4.1 Study design: dose-escalated and dose-dense epirubicin and paclitaxel. Dose-escalated (upper): epirubicin $110 \mathrm{mg} / \mathrm{m}^{2}+$ paclitaxel $200 \mathrm{mg} / \mathrm{m}^{2}$ Q 21 days, x 6, G-CSF day 2-14.

Dose-dense (lower): epirubicin $75 \mathrm{mg} / \mathrm{m}^{2}+$ paclitaxel $175 \mathrm{mg} / \mathrm{m}^{2} \mathrm{Q} 10$ days, x 6, G-CSF day 2-10 (black: epirubicin; dark gray: paclitaxel; light gray: G-CSF; white: no G-CSF).

\section{Dose modifications}

Toxicity was assessed after each course according to National Cancer Institute Common Toxicity Criteria version 1.0. A 20\% dose reduction of epirubicin and paclitaxel was recommended in case of nadir thrombocytopenia grade 4, neutropenia grade 4 for a period of more than seven days, febrile neutropenia and any nonhematological toxicity grade $\geq 3$ in the previous cycle. The neutrophil $(\geq 2,000 / \mu \mathrm{l})$ and platelet $(\geq 100,000 / \mu \mathrm{l})$ counts had to be recovered on the day of scheduled chemotherapy. In case of incomplete hematological recovery or persistence of nonhematological toxicity grade $\geq 2$ (excluding alopecia and anticipatory nausea and 
vomiting), treatment was delayed for a maximum period of two weeks. If a longer recovery period is needed the patient went off study.

Treatment had to be ceased in case of development of clinical cardiac failure or an absolute decrease in LVEF either $\geq 20 \%$ (EF absolute units) from baseline to a value above $50 \%$ or $\geq 10 \%$ to a value below $50 \%$.

\section{Study end points}

Tumor response evaluation of all known metastases was scheduled after cycle 3 and 6 by the same pre-study techniques. In addition, extra assessments had to be performed if there was clinical suspicion of progression. Standard UICC response criteria were applied.

\section{Statistical considerations}

The main objective of the study was to test whether a high response rate (overall response rate $\geq 80 \%$, with $\geq 15 \%$ complete remission) could be achieved with either dose-intensified schedules. A response rate of $60 \%$ or lower is also feasible with nontaxane combination chemotherapy, and considered not interesting for further investigation. Using a $90 \%$ power and a significance level of $5 \%$ in a Simon two-stage phase II design for $\mathrm{P} 1-\mathrm{P0}=0.20$, at least 45 for response evaluable patients in each arm were needed. Secondary objectives were to assess the progression-free interval, and evaluate the safety profiles and cardiac toxicity of these two approaches separately. If a patient continued or restarted with other antitumor therapy without objective progressive disease, the patient was censored on this date for progression-free survival.

\section{Results}

\section{Patient characteristics}

In total, 123 patients were entered and randomized in this study.

After inclusion of the first 18 patients (nine in both arms), an interim safety analysis was warranted due to an unexpected high number of dose-limiting toxicities in the dose-escalated arm. In contrast with our experiences in the phase I study, where only one out of 12 patients developed peripheral neurotoxicity during the first three cycles, in this study three out nine patients in the dose-escalated arm developed grade 2-3 neurotoxicity. These side-effects were debilitating for the patients and prevented the patients to undergo scheduled treatment. The dose of paclitaxel in this arm was therefore reduced to $200 \mathrm{mg} / \mathrm{m}^{2}$, a dose-level that was considered to be effective but presumably resulting in less peripheral neurotoxicity. In the dose-escalated arm a new cohort of patients was entered at this new dose level up to a total of 50 patients. Patients in the dose-dense arm continued to be entered at the original dose level. The 
randomization procedure was adapted temporarily to a 2:1 design in favor of the dose-escalated arm until the disappearance in imbalance of the number of patients.

So, 114 patients were randomized, excluding the first nine patients in the doseescalated arm. Of these, eight patients were shown not to be eligible because of; central nervous system tumor involvement $(n=3)$, too high prior adjuvant cumulative anthracycline dose $(n=2)$, other antitumor treatment started immediately after randomization but prior to scheduled chemotherapy (radiotherapy, $n=2$ ) and early withdrawal of consent $(n=1)$. All 106 eligible patients were evaluable for the safety analysis, 51 in the dose-escalated and 55 patients in the dose-dense arm. The patient characteristics in both study arms were well balanced (Table 4.1). Ten and eleven patients in each arm presented with primary metastatic disease and about half of the patients had undergone prior systemic adjuvant therapy and palliative endocrine therapy. In both arms there was a high number of patients with osseous, hepatic and/or lymph node metastases. About $40 \%$ of the patients had metastases in three or more organ systems.

Table 4.1 Patient characteristics.

\begin{tabular}{|c|c|c|c|c|}
\hline \multirow[t]{2}{*}{ Characteristics } & \multicolumn{2}{|c|}{$\begin{array}{c}\text { Dose-escalated } \\
\text { epirubicin/paclitaxel } \\
\qquad n=51\end{array}$} & \multicolumn{2}{|c|}{$\begin{array}{c}\text { Dose-dense } \\
\text { epirubicin/paclitaxel } \\
n=55\end{array}$} \\
\hline & $\mathrm{n}$ & $(\%)$ & $\mathrm{n}$ & (\%) \\
\hline Median age, years & 51 & (range $31-72$ ) & 53 & (range $29-69$ ) \\
\hline \multicolumn{5}{|l|}{ ECOG performance status } \\
\hline 0 & 23 & $(45)$ & 30 & (55) \\
\hline 1 & 24 & (47) & 24 & (44) \\
\hline 2 & 4 & (8) & 1 & $(2)$ \\
\hline \multicolumn{5}{|l|}{ Hormone receptor status } \\
\hline ER positive & 28 & (55) & 34 & $(62)$ \\
\hline PR positive & 26 & (51) & 31 & (56) \\
\hline Prior adjuvant systemic therapy & 20 & (40) & 26 & (47) \\
\hline Endocrine & 10 & (20) & 17 & (31) \\
\hline Chemotherapy, anthracyclines & 11 & (22) & 10 & (18) \\
\hline Chemotherapy, non-anthracyclines & 4 & (8) & 6 & (11) \\
\hline Median disease-free interval (months) & 28 & (range $0-143$ ) & 31 & (range $0-360$ ) \\
\hline Median MBC interval (months) & 2 & (range $0-76$ ) & 3 & (range 0-104) \\
\hline Primary metastatic & 10 & (20) & 11 & (20) \\
\hline Prior palliative endocrine therapy & 23 & (45) & 30 & (55) \\
\hline \multicolumn{5}{|l|}{ Metastatic sites } \\
\hline Osseous & 29 & (57) & 33 & $(60)$ \\
\hline Hepatic & 22 & (43) & 30 & (55) \\
\hline Pulmonary & 17 & (33) & 10 & (18) \\
\hline Lymph nodes / Soft tissue & $27 / 14$ & $(53 / 27)$ & $27 / 8$ & $(49 / 15)$ \\
\hline$\geq 3$ organ system localizations & 21 & (41) & 22 & (40) \\
\hline
\end{tabular}

ECOG, Eastern Cooperative Oncology Group; ER, estrogen receptor; PR, progesterone receptor; DFS Disease Free Survival interval= time interval between primary diagnosis of breast cancer and diagnosis of metastatic disease; $M B C$ interval= time interval between diagnosis of metastatic breast cancer and date of randomization. 


\section{Treatment summary}

In both arms, a median number of six cycles was delivered. Forty-two (82\%) patients completed all six treatment cycles in the dose-escalated arm, with $84 \%$ of the cycles delivered at $\geq 90 \%$ of scheduled dose-intensity. In the dose-dense arm, forty-three (78\%) patients completed all six treatment cycles, with $85 \%$ of the cycles delivered at $\geq 90 \%$ scheduled dose-intensity.

The median delivered cumulative doses and dose-intensities are displayed in Table 4.2 .

Table 4.2 Delivered treatment of epirubicin and paclitaxel.

\begin{tabular}{lcccccc}
\hline & \multicolumn{3}{c}{$\begin{array}{c}\text { Dose-escalated } \\
\text { epirubicin / paclitaxel }\end{array}$} & & \multicolumn{2}{c}{$\begin{array}{c}\text { Dose-dense } \\
\text { epirubicin / paclitaxel }\end{array}$} \\
\hline & $\begin{array}{c}\text { No of } \\
\text { patients }\end{array}$ & $\begin{array}{c}\text { median DI } \\
\mathrm{mg} / \mathrm{m}^{2} / \mathrm{wk} \\
\text { epirubicin }\end{array}$ & $\begin{array}{c}\text { median DI } \\
\mathrm{mg} / \mathrm{m}^{2} / \mathrm{wk} \\
\text { paclitaxel }\end{array}$ & $\begin{array}{c}\text { No of } \\
\text { patients }\end{array}$ & $\begin{array}{c}\text { median DI } \\
\mathrm{mg} / \mathrm{m}^{2} / \mathrm{wk} \\
\text { epirubicin }\end{array}$ & $\begin{array}{c}\mathrm{median} \mathrm{DI} \\
\mathrm{mg} / \mathrm{m}^{2} / \mathrm{wk} \\
\text { paclitaxel }\end{array}$ \\
\hline Cycle 1 & 51 & 37 & 67 & 55 & 53 & 123 \\
Cycle 2 & 49 & 37 & 67 & 55 & 53 & 123 \\
Cycle 3 & 49 & 37 & 67 & 53 & 53 & 123 \\
Cycle 4 & 45 & 37 & 67 & 52 & 48 & 112 \\
Cycle 5 & 44 & 37 & 67 & 49 & 52 & 122 \\
Cycle 6 & 42 & 37 & 67 & 43 & 52 & 122 \\
Overall & 280 & 36 & 67 & 307 & 51 & 120 \\
\hline
\end{tabular}

Median Cumulative

dose

epirubicin

paclitaxel

Median cumulative

total dose epirubicin ${ }^{2}$

Median treatment

duration (days)

\footnotetext{
\& Median total cumulative dose epirubicin; is the cumulative delivered amount of epirubicin during study protocol + eventually cumulative dose of adjuvant anthracycline.
}

448 (range 144 - 494)

1045 (range 349 - 1165)

$450(144-902)$

61 (range $20-102)$

\section{Efficacy}

Tumor response was assessable in 48 patients of the dose-escalated arm and 53 patients of the dose-dense arm (Table 5.3). The best overall response rate was $75 \%$ in the dose-escalated arm and $70 \%$ in the dose-dense arm. All patients ultimately developed progressive disease. The median progression-free survival was 6 months (95\% Cl 5.1-6.9) and 7 months (95\% Cl 5.6-8.4) for the dose-escalated arm and dosedense arm, respectively. The median overall survival was 16 months $(95 \% \mathrm{Cl}$ 12.1-20.0) and 14 months (95\% Cl 9.6-18.4), respectively. 
Table 4.3 Efficacy of epirubicin and paclitaxel, dose-escalated and dose-dense regimens.

\begin{tabular}{|c|c|c|c|c|}
\hline \multirow[b]{2}{*}{ No. receiving treatment } & \multicolumn{2}{|c|}{$\begin{array}{c}\text { Dose-escalated } \\
\text { epirubicin / paclitaxel }\end{array}$} & \multicolumn{2}{|c|}{$\begin{array}{c}\text { Dose-dense } \\
\text { epirubicin / paclitaxel }\end{array}$} \\
\hline & 51 & & 55 & \\
\hline Assessable for response & 48 & $(\%)$ & 53 & (\%) \\
\hline Overall & 36 & (75) & 37 & (70) \\
\hline Complete remission & 3 & $(6)$ & 3 & $(6)$ \\
\hline Partial remission & 33 & (69) & 34 & (64) \\
\hline Stable disease & 9 & (19) & 14 & $(26)$ \\
\hline Progressive disease & 3 & (6) & 2 & (4) \\
\hline Progression & 51 & $(100)$ & 55 & $(100 \%)$ \\
\hline Death & 48 & $(94 \%)$ & 54 & $(98 \%)$ \\
\hline Median PFS (months, 95\%Cl) & 6 & $(5.1-6.9)$ & 7 & $(5.6-8.4)$ \\
\hline Median OS (months, 95\% CI) & 16 & $(12.1-20.0)$ & 14 & $(9.6-18.4)$ \\
\hline Total MBC OS (months, 95\% Cl) & 24 & $(17.8-30.2)$ & 26 & $(15.6-36.4)$ \\
\hline
\end{tabular}

PFS, progression-free survival; OS, overall survival; MBC, metastatic breast cancer

\section{Toxicity}

In the dose-escalated arm, twenty-nine (57\%) patients had a dose-limiting toxicity at the starting dose-level (Table 4.4). Sixteen (31\%) patients encountered a grade $\geq 3$ toxicity, ten (20\%) patients had a delayed recovery at the time of the next scheduled cycle (partly overlapping reasons for dose-modifications), and four (8\%) patients showed an asymptomatic but significant decrease of the LVEF. After a first treatment modification, additional secondary dose-limiting toxicities occurred in 12 (24\%) patients. Of the grade $\geq 3$ toxicities, febrile neutropenia, thrombocytopenia and neurotoxicity were most frequently seen. Febrile neutropenic episodes all occurred during the first cycle $(n=6,12 \%)$; one patient died in a septic shock. Grade 3 neurotoxicity was observed in three $(6 \%)$ patients after the $3^{\text {rd }}, 4^{\text {th }}$ and $5^{\text {th }}$ cycle, respectively. In total eight patients showed an asymptomatic but significant decrease of the LVEF. Only one of these eight had received anthracycline-based chemotherapy in the adjuvant setting. The onset of cardiotoxicity occurred at a median total cumulative dose of epirubicin of $657 \mathrm{mg} / \mathrm{m}^{2}$ (range 556-778). One patient ultimately developed symptoms of cardiac failure nine months after stopping study treatment. In the dose-dense arm, 27 (49\%) patients had a dose-limiting toxicity at the starting dose-level. Fourteen (25\%) patients with a grade $\geq 3$ toxicity, two (4\%) patients with an asymptomatic but significant decrease of the LVEF and 11 (20\%) patients with a delayed recovery precluding the next scheduled cycle. After treatment-modification, $11(20 \%)$ patients encountered again dose-limiting toxicity which necessitated a further treatment-modification. Febrile neutropenia was observed in four (7\%) patients, of whom one with a fatal outcome after the $6^{\text {th }}$ cycle. One patient with active thromboembolic disease developed a cerebrovascular accident and pulmonary 
infection after the first cycle and died after the second cycle. Autopsy revealed extensive thromboembolic disease in lungs, liver and kidneys. Peripheral neurotoxicity grade $\geq 3$ was observed in five (9\%) patients. In total four patients developed an asymptomatic but significant decrease of the LVEF. Three of these four had received anthracycline combination chemotherapy in the adjuvant setting. In these patients the median total cumulative dose of epirubicin, $798 \mathrm{mg} / \mathrm{m}^{2}$ (range 420-850), was considerably higher than the subgroup without a fall in LVEF, $450 \mathrm{mg} / \mathrm{m}^{2}$ (range 144-902). One of these patients ultimately developed symptoms of cardiac failure three months later.

Table 4.4 Dose-limiting toxicities initially and later.

\begin{tabular}{|c|c|c|c|c|c|c|c|c|}
\hline \multirow{3}{*}{$\begin{array}{l}\text { Toxicities } \\
\text { No. Patients }\end{array}$} & \multicolumn{4}{|c|}{$\begin{array}{c}\text { Dose-escalated } \\
n=51\end{array}$} & \multicolumn{4}{|c|}{$\begin{array}{l}\text { Dose-dense } \\
n=55\end{array}$} \\
\hline & \multicolumn{2}{|c|}{$\begin{array}{c}\text { Initial toxicity } \\
\mathrm{n}(\%)\end{array}$} & \multicolumn{2}{|c|}{$\begin{array}{l}\text { Later toxicity } \\
\mathrm{n}(\%)\end{array}$} & \multicolumn{2}{|c|}{$\begin{array}{c}\text { Initial toxicity } \\
\mathrm{n}(\%)\end{array}$} & \multicolumn{2}{|c|}{$\begin{array}{l}\text { Later toxicity } \\
\mathrm{n}(\%)\end{array}$} \\
\hline & 29 & (57) & 12 & (24) & 27 & (49) & 11 & (20) \\
\hline $\mathrm{NCl}-\mathrm{CTC} \geq$ grade 3 & 16 & (31) & 4 & (8) & 14 & (25) & 4 & (7) \\
\hline Neutropenic fever & 6 & (12) & 1 & (2) & 4 & (7) & & \\
\hline Platelets, grade IV & 5 & (10) & 2 & (4) & 3 & (5) & 1 & (2) \\
\hline Neurotoxicity & 3 & (6) & & & 5 & (9) & 2 & (4) \\
\hline Infection & 2 & (4) & 1 & (2) & 1 & (2) & & \\
\hline Gastro-intestinal & 1 & (2) & & & 4 & (7) & 1 & (2) \\
\hline Skin & & & & & & & 1 & (2) \\
\hline $\begin{array}{l}\text { Cardiac, serious event } \\
\text { Symptomatic }\end{array}$ & 4 & (8) & 4 & (8) & 2 & (4) & 2 & (4) \\
\hline Asymptomatic & 4 & (8) & 4 & (8) & 2 & (4) & 2 & (4) \\
\hline Delayed recovery & 10 & (20) & 4 & (8) & 11 & (20) & 5 & (9) \\
\hline Neutrophils & 1 & (2) & & & 2 & (4) & 1 & (2) \\
\hline Platelets & 3 & (6) & 3 & (6) & 1 & (2) & 2 & (4) \\
\hline Neurotoxicity & 1 & (2) & 1 & (2) & 2 & (4) & 2 & (4) \\
\hline Infection & 3 & (6) & & & 5 & (9) & & \\
\hline Miscellaneous & 3 & (6) & & & 2 & (4) & & \\
\hline
\end{tabular}

\section{Discussion}

In this randomized phase II study two different approaches of dose-intensification of an anthracycline/taxane combination were tested for their outcome on response rate, progression-free survival and safety profile as first-line chemotherapy in patients with advanced breast cancer. Both arms appeared to be very effective with response rates of $70 \%$ and more. Already after three cycles of chemotherapy the response rates were $51 \%$ for the dose-dense regime (after one month of treatment) and $55 \%$ for the doseescalated regime (after two months of treatment), respectively. Despite the almost halved treatment duration in the dose-dense arm, the progression-free survival 
seemed to be quite comparable for both treatment arms. Or, in other words, with a much shorter treatment period and a lower cumulative chemotherapy dose, patients remained longer off-treatment. For the dose-dense regime the treatment-free period was five months, whereas for the dose-escalated regime this was only two months. Obviously, apart from the benefit for the patient also from an economic viewpoint this may be an interesting observation.

Also, different toxicity frequencies were observed, with a better overall profile for the dose-dense regime. In the dose-escalated arm there was a higher incidence of hematological toxicity showing more febrile neutropenia (14\% vs. $7 \%$ ), despite the use of primary G-CSF prophylaxis, and more grade four thrombocytopenia ( $14 \%$ vs. $7 \%$ ). A higher incidence of mainly asymptomatic cardiac toxicity was also observed in the dose-escalated arm ( $16 \%$ vs. $8 \%$ ), likely associated with the higher cumulative dose of epirubicin in this arm, but also the interaction between epirubicin and paclitaxel may have played a role. Others have reported that the combination of doxorubicin and paclitaxel was associated with the development of heart failure at cumulative doxorubicin doses much lower than usual. ${ }^{2}$ Grade 3 or higher peripheral neurotoxicity was observed in $6 \%$ and $13 \%$ of the patients with the dose-escalated and dose-dense regime, respectively. In the CALGB 9840 trial it was shown that weekly paclitaxel was indeed associated with significantly more grade 3 neuropathy than the every threeweek therapy. ${ }^{14}$ However, as weekly paclitaxel was superior to every-three-weeks administration in terms of response, median time to progression and overall survival, it is now generally appreciated that if there is an indication for paclitaxel in advanced breast cancer, it should be used in a weekly dense schedule. The superiority of the weekly paclitaxel schedule over a 3-weekly schedule, after four cycles of doxorubicin and cyclophosphamide, was also confirmed in the adjuvant setting (ECOG 1199). ${ }^{15}$

The introduction of G-CSF permitted the administration of myelosuppressive chemotherapy in intervals shorter than the conventional three weeks. However, although post-chemotherapy G-CSF reduces neutropenia, G-CSF shortly before chemotherapy may increase myelotoxicity. Timmer-Bonte et al. showed that during dose-densified chemotherapy daily G-CSF until two days before the next cycle compared to G-CSF until five days before the next chemotherapy cycle significantly worsened the degree of thrombocytopenia of that next cycle. ${ }^{16}$ Timely withdrawal of G-CSF during dose-densified chemotherapy was advised, to reduce chemotherapyrelated thrombocytopenia without jeopardizing neutrophil recovery. In the present study, we administered G-CSF on days 2-10 in the dose-dense arm and on days 2-14 in the dose-escalated arm. Nevertheless, the incidence of grade 4 thrombocytopenia was not increased but seemed to be even lower in the dose-dense arm when compared with the dose-escalated arm. That weekly paclitaxel was also less myelosuppressive than 3-weekly paclitaxel was also observed by others. ${ }^{14}$

Cytotoxic therapy generally induces tumor regression with repeated cycles. Smaller tumors theoretically experience greater log kill (cell kill on a logarithmic scale) when chemotherapy is applied, because they are growing more rapidly than larger tumors 
of the same kinetics. However there is always re-growth between treatment cycles. The Norton-Simon hypothesis model suggests that chemotherapy is more effective by giving pulses of chemotherapy at a greater dose rate. ${ }^{10,11}$ By minimizing the regrowth of cancer between cycles of treatment, the cumulative cell kill might be enhanced and thereby achieving a greater therapeutic effect. The CALGB 9741 trial in node positive early breast cancer tested in a $2 \times 2$ factorial design the role of sequential versus concurrent chemotherapy and conventional three-weekly intervals versus "dose dense" 2-weekly intervals. ${ }^{17}$ Although the cumulative doses of doxorubicin, cyclophosphamide and paclitaxel were equal in the four arms, the dose intensities were quite different. The dose-dense approach resulted in a reduced annual odds for disease-recurrence of $26 \%$. Interestingly, the dose-dense arms were also associated with less severe neutropenia and neutropenic fever, compared with the conventional treatment arms.

Also in advanced ovarian cancer densification of chemotherapy has been investigated by a Japanese study group in a randomized phase 3 study. As first line treatment six cycles of either paclitaxel ( $180 \mathrm{mg} / \mathrm{m}^{2} ; 3-\mathrm{h}$ intravenous infusion) plus carboplatin AUC $6 \mathrm{mg} / \mathrm{ml}$ per min, given on day 1 of a 21-day cycle was compared with dose-dense paclitaxel ( $80 \mathrm{mg} / \mathrm{m}^{2}$; 1 -h intravenous infusion) given on days 1,8 , and 15 plus carboplatin given on day 1 of a 21-day cycle. In comparison with the conventional treatment group the dose-dense treatment group showed a statistically significant improved median progression free survival ( 28.0 vs. 17.2 months) and 3 years overall survival $(72.1 \%$ vs. $65.1 \%)$. However the dose dense treatment resulted in more frequent hematological toxicity, mainly neutropenia and anemia. ${ }^{18}$

When discussing dose density, it is also important to take the issue of combination versus sequential administration of cytotoxic drugs into account. With sequential schedules, one can aim at a higher dose intensity per drug, but it ignores the concept of 'non-overlapping' resistance mechanisms which may be better addressed by combination chemotherapy. There are several randomized trials that have directly compared the combination versus sequence of anthracyclines and taxanes in the advanced breast cancer setting. ${ }^{19-21}$ None of these showed a survival benefit, although a higher response rate and longer time to treatment failure with the combination was observed in one trial. ${ }^{19}$ However, the concept of maximizing the dose intensity in the sequence using single-agents was not tested. Further of note, the impact of densification may be different for a drug like paclitaxel than for an anthracycline. ${ }^{14,22}$ At present, in the absence of specific predictive factors to select a subgroup of responsive patients, combination chemotherapy may be preferentially reserved for patients with rapidly progressing visceral metastatic disease, or in the emergency situations in which a rapid response is warranted. ${ }^{23}$

In conclusion, we observed that dose-dense and dose-escalated chemotherapy of the combination epirubicin and paclitaxel was quite effective. The dose-dense regime seemed to be the preferred schedule, because of less side effects. Dose-dense also seemed to be more attractive as the treatment was administered over only 60 days 
compared to almost 130 days in the three-weekly dose-escalated schedule. With a comparable time-to-progression this shorter treatment schedule resulted in a substantial longer off-treatment period. We feel that in breast cancer the concept of dose-density warrants further testing. 


\section{References}

1. A'Hern RP, Smith IE, Ebbs SR. Chemotherapy and survival in advanced breast cancer: the inclusion of doxorubicin in Cooper type regimens. Br J Cancer 1993;67:801-805.

2. Gianni L, Munzone E, Capri G, Fulfaro F, Tarenzi E, Villani F, Spreafico C, Laffranchi A, Caraceni A, Martini $C$, et al. Paclitaxel by 3-hour infusion in combination with bolus doxorubicin in women with untreated metastatic breast cancer: high antitumor efficacy and cardiac effects in a dose-finding and sequence-finding study. J Clin Oncol 1995;13:2688-2699.

3. Gehl J, Boesgaard M, Paaske T, Vittrup Jensen B, Dombernowsky P. Combined doxorubicin and paclitaxel in advanced breast cancer: effective and cardiotoxic. Ann Oncol 1996;7:687-693.

4. Jassem J, Pieńkowski T, Płuzańska A, Jelic S, Gorbunova V, Mrsic-Krmpotic Z, Berzins J, Nagykalnai T, Wigler N, Renard J, Munier S, Weil C; Central \& Eastern Europe and Israel Pacitaxel Breast Cancer Study Group. Doxorubicin and paclitaxel versus fluorouracil, doxorubicin, and cyclophosphamide as first-line therapy for women with metastatic breast cancer: final results of a randomized phase III multicenter trial. J Clin Oncol 2001;19:1707-1715.

5. Bontenbal M, Creemers GJ, Braun HJ, de Boer AC, Janssen JT, Leys RB, Ruit JB, Goey SH, van der Velden PC, Kerkhofs LG, Schothorst KL, Schmitz PI, Bokma HJ, Verweij J, Seynaeve C; Dutch Community Setting Trial for the Clinical Trial Group. Phase II to III study comparing doxorubicin and docetaxel with fluorouracil, doxorubicin, and cyclophosphamide as first-line chemotherapy in patients with metastatic breast cancer: results of a Dutch Community Setting Trial for the Clinical Trial Group of the Comprehensive Cancer Centre. J Clin Oncol 2005;23:7081-7088.

6. Biganzoli L, Cufer T, Bruning P, Coleman R, Duchateau L, Calvert AH, Gamucci T, Twelves C, Fargeot P, Epelbaum R, Lohrisch C, Piccart MJ. Doxorubicin and paclitaxel versus doxorubicin and cyclophosphamide as first-line chemotherapy in metastatic breast cancer: The European Organization for Research and Treatment of Cancer 10961 Multicenter Phase III Trial. J Clin Oncol 2002;20: 3114-3121

7. Langley RE, Carmichael J, Jones AL, Cameron DA, Qian W, Uscinska B, Howell A, Parmar M. Phase III trial of epirubicin plus paclitaxel compared with epirubicin plus cyclophosphamide as first-line chemotherapy for metastatic breast cancer: United Kingdom National Cancer Research Institute trial AB01. J Clin Oncol 2005;23:8322-8330.

8. Nabholtz JM, Falkson C, Campos D, Szanto J, Martin M, Chan S, Pienkowski T, Zaluski J, Pinter T, Krzakowski M, Vorobiof D, Leonard R, Kennedy I, Azli N, Murawsky M, Riva A, Pouillart P; TAX 306 Study Group. Docetaxel and doxorubicin compared with doxorubicin and cyclophosphamide as firstline chemotherapy for metastatic breast cancer: results of a randomized, multicenter, phase III trial. J Clin Oncol 2003;21:968-975.

9. Jain KK, Casper ES, Geller NL, Hakes TB, Kaufman RJ, Currie V, Schwartz W, Cassidy C, Petroni GR, Young $\mathrm{CW}$, et al. A prospective randomized comparison of epirubicin and doxorubicin in patients with advanced breast cancer. J Clin Oncol 1985;3:818-826.

10. Norton L, Simon R. The Norton-Simon hypothesis revisited. Cancer Treat Rep 1986;70:163-169.

11. Norton L. Conceptual and practical implications of breast tissue geometry: toward a more effective, less toxic therapy. Oncologist 2005;10:370-381.

12. Lalisang RI, Wils JA, Nortier HW, Burghouts JT, Hupperets PS, Erdkamp FL, Schouten HC, Blijham GH. Comparative study of dose escalation versus interval reduction to obtain dose-intensification of epirubicin and cyclophosphamide with granulocyte colony-stimulating factor in advanced breast cancer. J Clin Oncol 1997;15:1367-1376.

13. Lalisang RI, Wils JA, Nortier HW, Burghouts JT, Hupperets PS, Erdkamp FL, Schouten HC, Blijham GH. Comparative study of dose escalation versus interval reduction to obtain dose-intensification of epirubicin and cyclophosphamide with granulocyte colony-stimulating factor in advanced breast cancer. J Clin Oncol 1997; 15:1367-1376.

14. Seidman AD, Berry D, Cirrincione C, Harris L, Muss H, Marcom PK, Gipson G, Burstein H, Lake D, Shapiro CL, Ungaro P, Norton L, Winer E, Hudis C. Randomized phase III trial of weekly compared with every-3-weeks paclitaxel for metastatic breast cancer, with trastuzumab for all HER-2 overexpressors and random assignment to trastuzumab or not in HER-2 nonoverexpressors: final results of Cancer and Leukemia Group B protocol 9840. J Clin Oncol 2008;26:1642-1649. 
15. Sparano JA, Wang M, Martino S, Jones V, Perez EA, Saphner T, Wolff AC, Sledge GW Jr, Wood WC, Davidson NE. Weekly paclitaxel in the adjuvant treatment of breast cancer. N Engl J Med 2008;358: 1663-1671

16. Timmer-Bonte JN, de Mulder PH, Peer PG, Beex LV, Tjan-Heijnen VC. Timely withdrawal of G-CSF reduces the occurrence of thrombocytopenia during dose-dense chemotherapy. Breast Cancer Res Treat 2005;93:117-123.

17. Citron ML, Berry DA, Cirrincione C, Hudis C, Winer EP, Gradishar WJ, Davidson NE, Martino S, Livingston R, Ingle JN, Perez EA, Carpenter J, Hurd D, Holland JF, Smith BL, Sartor Cl, Leung EH, Abrams J, Schilsky RL, Muss HB, Norton L. Randomized trial of dose-dense versus conventionally scheduled and sequential versus concurrent combination chemotherapy as postoperative adjuvant treatment of node-positive primary breast cancer: first report of Intergroup Trial C9741/Cancer and Leukemia Group B Trial 9741. J Clin Oncol 2003;21:1431-1439.

18. Katsumata N, Yasuda M, Takahashi F, Isonishi S, Jobo T, Aoki D, Tsuda H, Sugiyama T, Kodama S, Kimura E, Ochiai K, Noda K; Japanese Gynecologic Oncology Group. Dose-dense paclitaxel once a week in combination with carboplatin every 3 weeks for advanced ovarian cancer: a phase 3, openlabel, randomised controlled trial. Lancet. 2009;374:1331-1338.

19. Sledge GW, Neuberg D, Bernardo P, Ingle JN, Martino S, Rowinsky EK, Wood WC. Phase III trial of doxorubicin, paclitaxel, and the combination of doxorubicin and paclitaxel as front-line chemotherapy for metastatic breast cancer: an intergroup trial (E1193). J Clin Oncol 2003;21:588-592.

20. Alba E, Martín M, Ramos M, Adrover E, Balil A, Jara C, Barnadas A, Fernández-Aramburo A, SánchezRovira P, Amenedo M, Casado A; Spanish Breast Cancer Research Group. Multicenter randomized trial comparing sequential with concomitant administration of doxorubicin and docetaxel as first-line treatment of metastatic breast cancer: a Spanish Breast Cancer Research Group (GEICAM-9903) phase III study. J Clin Oncol 2004;22:2587-2593.

21. Conte PF, Guarneri V, Bruzzi P, Prochilo T, Salvadori B, Bolognesi A, Aldrighetti D, Venturini M, Rosso R, Mammoliti S, Carnino F, Giannessi P, Costantini M, Moyano A, Baldini E; Gruppo Oncologico Nord Ovest. Concomitant versus sequential administration of epirubicin and paclitaxel as first-line therapy in metastatic breast carcinoma: results for the Gruppo Oncologico Nord Ovest randomized trial. Cancer 2004;101:704-712.

22. Biganzoli L, Piccart MJ. The bigger the better? ... or what we know and what we still need to learn about anthracycline dose per course, dose density and cumulative dose in the treatment of breast cancer. Ann Oncol 1997;8: 177-1182.

23. Colozza M, de Azambuja E, Personeni N, Lebrun F, Piccart MJ, Cardoso F. Achievements in systemic therapies in the pregenomic era in metastatic breast cancer. Oncologist 2007;12:253-270. 

High-dose chemotherapy with autologous bone marrow support as consolidation after standard-dose adjuvant therapy in primary breast cancer patients with 7 or more involved axillary lymph nodes

Lalisang RI, Hupperets PSGJ, ten Haaft MA, Jansen RLH, Schouten HC Bone Marrow Transplantation 1998;21:243-247 


\section{Summary}

\section{Background}

Despite adjuvant chemotherapy the prognosis of patients with breast cancer and a high number of involved axillary lymph nodes is very poor. The aim of the present study was to evaluate the efficacy of high dose chemotherapy with autologous bone marrow support in patients with 7 or more involved axillary lymph nodes.

\section{Patients and Methods}

Nineteen patients underwent 4 courses of standard adjuvant chemotherapy, followed by high dose Busulphan/Cyclophosphamide chemotherapy with autologous bonemarrow support.

\section{Results}

The median age was 41.4 years and the median number of involved lymph nodes was 11 . Mucositis WHO grade $\geq 3$ was observed in 15 patients and 18 patients suffered febrile neutropenia. Transplant related mortality was encountered by 2 patients, due to hepatic veno-occlusive disease and sepsis complicated by multi-organ failure, respectively. After a median follow-up period of 1490 days (range 582-2024 days) from diagnosis 9 patients have relapsed and the overall event-free survival (EFS) is $42 \%$ (95\% Cl 19-65\%). The median EFS is 487 days.

\section{Conclusion}

High-dose treatment with BuCy2 in high-risk breast cancer patients is a toxic regimen and does not seem to improve the disease-free survival. 


\section{Introduction}

Adjuvant chemotherapy has demonstrated a modest, but consistent improvement in long term disease-free and overall survival in primary breast cancer patients. ${ }^{1}$ The prognosis of patients with primary breast cancer is inversely related to the number of involved axillary lymph nodes at surgery. Analysis of treatment outcomes in patients with 4-9 positive lymph nodes indicates that $50-60 \%$ will relapse by 5 years and $60-70 \%$ will relapse by 10 years. $^{2-4}$ The outcome of patients with 10 or more positive lymph nodes is even worse, at 5 -years $55-87 \%$ and at 10 years $70-90 \%$ have relapsed, respectively. ${ }^{2-6}$ Twenty year follow-up data from the CMF Milan experience suggest that even at that time no plateau has been reached. ${ }^{7}$

Several studies and retrospective analyses suggest a significant dose-response relationship in metastatic and primary breast cancer. ${ }^{8-11}$ Attempts to further improve these results by increasing the dose of chemotherapy have met only limited success, mainly due to profound myelosuppression. Autologous bone marrow support (ABMS) offers an opportunity to overcome this problem, but whether this will lead to better results remains to be determined.

High dose cyclophosphamide has been shown to induce responses in a variety of relapsed or refractory malignancies and has been part of double alkylator therapy with autologous bone marrow support in advanced breast cancer. ${ }^{12-14}$ Alkylating agents have shown a steep dose-response relationship in vitro and, when combined, act synergistically to produce response rates higher than these produced by single agents alone. $^{15,16}$

The preparative regimen busulphan and cyclophosphamide (BuCy) has been introduced by Santos and colleagues for the treatment of acute non-lymphoblastic leukaemia. ${ }^{17}$ This regimen was altered to decrease the toxicity of cyclophosphamide (BuCy2) by Tutschka and coworkers without apparent loss of efficacy. ${ }^{18}$ Experience with BuCy2 showed a relatively low treatment related morbidity, making this bialkylator preparative regimen potentially attractive for the treatment of solid tumors. $^{19}$

In 1991 we started a phase II study to address the question whether adjuvant chemotherapy followed by high dose consolidation with busulphan and cyclophosphamide supported by bone marrow transplantation may improve the prognosis of patients with primary breast cancer and 7 or more positive axillary lymph nodes. 


\section{Materials and methods}

\section{Patients}

Patients were eligible if they had histologically proven invasive breast cancer, stage II or III, and at lumpectomy or mastectomy with axillary node dissection, 7 or more positive lymph nodes. After surgery clear surgical margins were required at pathologic examination, without signs of locoregional or metastatic disease. No formal extensive staging studies except for chest X-ray, bone-scintigraphy and routine laboratory examination (complete blood cell counts and biochemistry profile) was done. Patients were between 18 and 55 years of age, with a good performance status (ECOGZUBROD <2), adequate bone marrow, cardiopulmonary, neurologic, liver and renal function and without prior malignancies. The estrogen-receptor status was assessed on the primary tumor by immunochemistry (Diagnostic Products Corporation Nederland Ltd, The Netherlands). Informed consent was obtained from all patients.

\section{Treatment program}

Patients were treated with 3 cycles of standard adjuvant combination chemotherapy. Five patients with a lumpectomy underwent concurrent radiotherapy of the involved breast. Bone marrow was harvested 4 weeks after the third cycle if routine physicaland laboratory-examination appeared normal. The bone marrow was harvested under general anesthesia by multiple aspirations from both posterior iliac crests and at least $0.5 \times 10^{8}$ nucleated cells $/ \mathrm{kg}$ body weight had to be collected. A buffy coat concentrate was cryopreserved using $10 \%$ dimethyl sulfoxide, frozen at controlled rate and stored in liquid nitrogen. After the harvesting procedure a fourth chemotherapy cycle was administered. Between 4 and 6 weeks after this fourth cycle patients were admitted for the high dose consolidation chemotherapy. All patients had a double-lumen central venous catheter placed and were cared in private rooms with positivepressure, high efficiency particle filtration air system. Prophylactic measures consisted of a low bacterial and low fungal content diet, oral fungostatics and oral quinolones. The high dose chemotherapy program consisted of busulphan $4 \mathrm{mg} / \mathrm{kg} \mathrm{p.o.} \mathrm{in} \mathrm{divided}$ doses daily days -7 till -4 (total dose $16 \mathrm{mg} / \mathrm{kg}$ ) and cyclophosphamide $60 \mathrm{mg} / \mathrm{kg}$ once daily i.v. on days -3 and -2 (total dose $120 \mathrm{mg} / \mathrm{kg}$ ), followed by bone marrow reinfusion on day 0 . Throughout the treatment course hemoglobin level was maintained above $6 \mathrm{mmol} / \mathrm{l}$ and platelet count above $10 \times 10^{9} / \mathrm{l}$ by transfusion of irradiated leukocyte-poor donor red cells and random platelets. During the study period the hematopoietic growth factors GM-CSF and later G-CSF became available, and were administered, according to local protocols in a dose of $5 \mu \mathrm{gr} / \mathrm{kg}$ body weight, from day 1 until leukocyte recovery $\geq 3 \times 10^{9} /$. Cultures were performed for bacterial and fungal infections if a patients temperature was greater than $38.5^{\circ} \mathrm{C}$. Febrile neutropenic patients were treated empirically by a standardized antibiotic 
protocol. Prescription of tamoxifen after hematologic recovery was left to the discretion of the physician.

\section{Follow-up}

After transplantation patients were followed with monthly controls in the first year and three monthly controls later, using history, routine physical examination, liver enzyme testing and yearly mammography.

\section{Statistics}

Event-free survival (EFS) was defined as the time from surgery until relapse or death. Overall survival (OS) was calculated from surgery until death. The Kaplan-Meier product limit method was used to estimate OS and EFS. ${ }^{20}$

\section{Results}

\section{Patients}

In the period from November 1991 till October 1995, 19 patients were entered in the study. The median age at diagnosis was 41.4 years (range 23-53.8). The median number of positive lymph nodes was 11 (range 7-29) out of median number of 17 (range 7-34) analyzed (Table 5.1). Three patients had 7-9, 13 patients $10-20$ and 3 patients $\geq 21$ involved lymph nodes, respectively. The estrogen-receptor was positive in 9 patients.

\section{Toxicity of high dose chemotherapy}

During the conditioning regimen all patients suffered from nausea and vomiting which was alleviated by selective 5 -HT3 antagonists. Mucositis WHO grade $\geq 3$ was observed in 15 patients, making total parenteral nutrition necessary in 12 patients. After the high-dose chemotherapy, the median duration from bone marrow reinfusion to ANC $>0.5 \times 10^{9} /$ I was 12 days (range 11-26). The median duration to unsupported platelets $\geq 20 \times 10^{9} /$ I was 32 days (range 12-131) days. Eighteen patients suffered from one or more episodes of febrile neutropenia. Transplant related mortality was encountered by 2 patients both without evidence of relapse (Table 5.1, pat. no. 6 and 19). One patient died at day 58 post transplant due to a complicated acalculus cholecystitis with septicemia and ultimately a multiple organ failure. The second patient developed 60 days post transplant a progressive hepatic veno-occlusive disease (VOD), complicated by an interstitial pneumonitis, and ultimately died 131 days posttransplant. VOD was also observed in another patient 37 days posttransplant, with an uneventful recovery. 


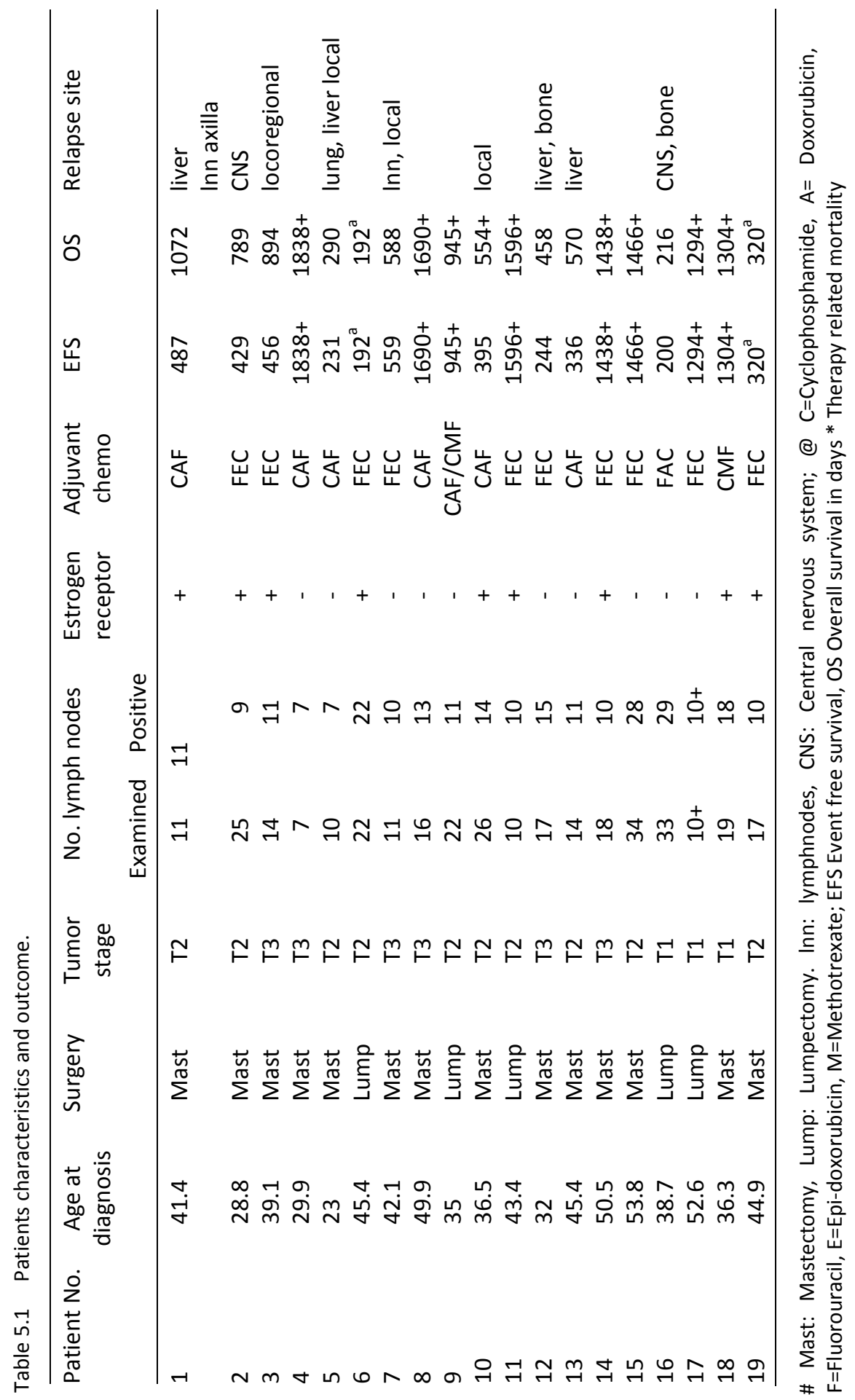




\section{Survival}

After a median follow-up of 1490 days (range 582-2024 days) from diagnosis the overall EFS is $42 \%$ (95\% Cl $19-65 \%)(F i g u r e ~ 5.1)$. The median EFS is 487 days (192$1838+)$ and the median OS was reached after 894 days. There were two treatment related deaths. Nine out of 17 remaining patients developed relapsed disease, with a median time to relapse of 395 days (range 200-559). Six patients had systemic relapses with localizations in the liver, bone, lung, central nervous system and/or bone marrow (Table 5.2). One patient relapsed only in the CNS. One patient relapsed locoregionally, and was treated with radiotherapy, and she developed liver and bone metastasis seven months later. Another patient relapsed at the mastectomy scar and was treated with local excision and radiotherapy.

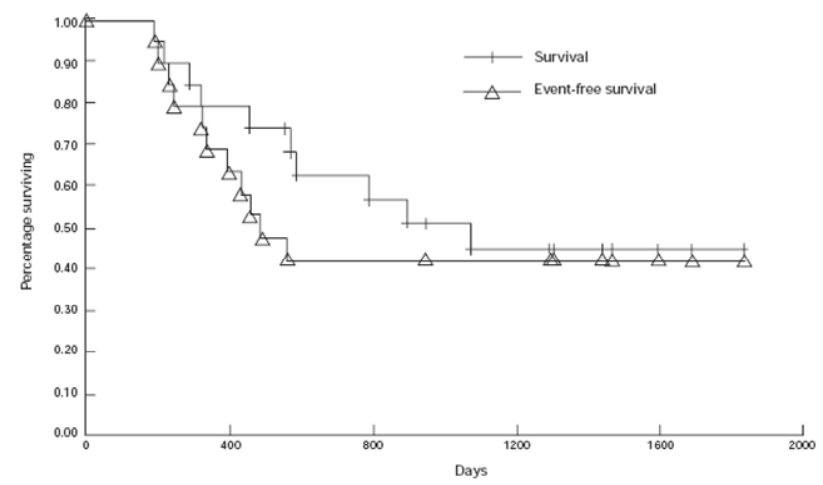

Figure 5.1 Actuarial probability of overall survival $(-\mid-)$ and event-free survival $(-\Delta-)$ for patients with primary breast cancer with seven or more involved auxillary lymph nodes, treated with consolidation high-dose chemotherapy and autologous bone marrow support.

\section{Discussion}

We report our results of conventional adjuvant chemotherapy followed by high dose BuCy2 chemotherapy with autologous bone marrow support in patients with primary breast cancer and at least 7 involved axillary lymph nodes. With a relatively short follow-up we encountered a disappointing disease-free survival (42\%), which may be comparable with the results of conventional adjuvant chemotherapy.

At Duke University, in a phase II study Peters applied high dose cyclophosphamide, cisplatinum and carmustine with autologous stem cell support as consolidation after 4 cycles of standard dose adjuvant chemotherapy treatment of primary breast cancer involving 10 or more axillary nodes. ${ }^{21}$ At a median follow-up of 2,5 years the DFS was $72 \%$. At a recent update with a median follow-up of 5 -years the DFS was $68 \%{ }^{22}$ De Graaf reported his experience of high dose consolidation with autologous bone 
marrow support in patients with five or more positive axillary lymph nodes. ${ }^{23}$ With a median follow-up of 36 months the DFS was $84 \%$. Several investigators reported recently their experiences with high dose consolidation in this high risk breast cancer patient group. With a relatively short median follow-up (7-16 months) the disease free survival shows a broad range between $67 \%$ and $90 \% .{ }^{24-27}$ Garcia-Conde reported the Spanish results of a phase II study of high-dose consolidation in patients with 10 or more involved lymph nodes and observed a 2 -years DFS of $80 \%$ and a 4 -years DFS of $70 \%$, respectively. ${ }^{28}$

How can we explain this discrepancy in results? It should be noted that in our trial the patients were not screened intensively for metastatic disease at diagnosis, neither at time of bone marrow harvest. From a recent report we know when patients with 10 or more positive nodes are screened more vigorously, with bone marrow biopsies and computed tomography scans, up to $27 \%$ are found to have detectable disease, that would have been missed with our pre-study screening. ${ }^{30}$

Although pre-study screening/selection may explain that our results are disappointing and comparable with the results of conventional adjuvant chemotherapy treatment in this high risk patient group, other explanations should also be considered. Up to now our study is the only one which has applied BuCy2 as high dose consolidation in adjunct to conventional adjuvant chemotherapy in this high risk patient group. Klumpp investigated a standard BuCy preparative regimen in patients with advanced chemo sensitive breast cancer. ${ }^{31}$ Despite a complete response rate of $73 \%$, all patients subsequently progressed, with a median time to progression of 164 days. Kalaycioglu applied BuCy2 in patients with metastatic breast cancer who had responded to either standard chemotherapy or radiotherapy. ${ }^{32}$ The median time to progression was 7 months and the 2 -years progression free survival was $25 \%$, which is comparable with the results of several other reports investigating different preparative regimens. Therefore, it is not likely that BuCy2 is an inferior conditioning regimen.

The relatively high mortality rate (11\%) and small sample size (19 patients) do not allow firm conclusions. In conclusion our data do not seem to support the use of high dose BuCy2 chemotherapy followed by stem cell transplantation as adjuvant therapy in high risk primary breast cancer.

Presently two large cooperative group (ECOG, CALGB) randomized trials are evaluating the role of high dose chemotherapy in patients with 10 or more positive nodes are ongoing. In January 1994 a randomized study has been started in The Netherlands to investigate the value of HDCT in patients with four or more involved axillary lymph nodes. The results of these randomized studies should determine if high dose chemotherapy will have a definitive place. 


\section{References}

1 Anonymous. Early Breast Cancer Collaborative Group. Systemic treatment of early breast cancer by hormonal, cytotoxic, or immunotherapy. Lancet 1992;339:1-15, 71-85.

2 Clark GM, McGuire WL. Steroid receptors and other prognostic factors in primary breast cancer. Sem Oncol 1988;15 (2 Suppl 1):20-25.

3 Buzzoni R, Bonadonna G, Valagussa P, Zambetti M. Adjuvant chemotherapy with doxorubicin plus cyclophosphamide, methotrexate and fluorouracil in the treatment of resectable breast cancer with more than three positive axillary nodes. J Clin Oncol 1991;9:2134-2140.

4 Cascinelli N, Greco M, Morabito A, Bufalino R, Testori A, Baldini MT, Andreola S, Leo E, Galluzzo D, Rilke F. Comparison of long term survival of 1986 consecutive patients with breast cancer treated at the National Institute of Cancer of Milano, Italy (1971-1972 and 1977-1978). Cancer 1991;68:427-434.

5 Buzdar AU, Kau SW, Hortobagyi GN, Ames FC, Holmes FA, Fraschini G, Hug V, Theriault RL, McNeese $M D$, Singletary SE. Clinical course of patients with breast cancer with ten or more positive nodes who were treated doxorubicin-containing adjuvant therapy. Cancer 1992;69:448-452.

6 Rivkin SE, Green S, Metch B, Glucksberg H, Gad-el-Mawla N, Constanzi JJ, Hoogstraten B, Athens J, Maloney T, Osborne CK, et al. Adjuvant CMFVP versus Melphalan for operable breast cancer with positive axillary nodes: 10-year results of a South West Oncology Group study. J Clin Oncol 1989;7: 1229-1238.

7 Bonadonna G, Valagussa P, Moliterni A, Zambetti M, Brambilla C. Adjuvant cyclophosphamide, methotrexate and fluorouracil in node positive breast cancer: The results of 20 years of follow-up. New Engl J Med 1995; 332: 901-906.

8 Hryniuk W, Bush $\mathrm{H}$. The importance of dose-intensity in chemotherapy of metastatic breast cancer. J Clin Oncol 1984;2:1281-1288.

9 Abeloff MD, Beveridge RA, Donehower RC, Fetting JH, Davidson NE, Gordon GG, Waterfield WC, Damron DJ. Sixteen week dose-intensive chemotherapy in the adjuvant treatment of breast cancer. J Natl Cancer Inst 1990;82:570-574.

10 Tannock IF, Boyd NF, DeBoer G, Erlichman C, Fine S, Larocque G, Mayers C, Perrault D, Sutherland H. A randomized trial of two dose levels of cyclophosphamide, methotrexate, and fluorouracil chemotherapy for patients with metastatic breast cancer. J Clin Oncol 1988;6:1377-1387.

11 Budman DR, Wood W, Henderson IC, et al. Initial findings of CALGB 8541: A dose and dose intensity trial of cyclophosphamide (C), doxorubicin (A), and 5-fluorouracil (F) as adjuvant treatment of stage II, node + , female breast cancer. Proc Am Soc Clin Oncol 1992;11:51 (abstr 29).

12 Collins C, Mortimer J, Livingston RB. High-dose cyclophosphamide in the treatment of refractory lymphomas and solid tumor malignancies. Cancer 1989;63:228-232.

13 Peters WP, Eder JP, Henner WD, Schryber S, Wilmore D, Finberg R, Schoenfeld D, Bast R, Gargone B, Antman $\mathrm{K}$, et al. High-dose combination alkylating agents with autologous bone marrow support: $\mathrm{A}$ phase I trial. J Clin Oncol 1986;4:646-654.

14 Antman K, Gale RP. Advanced breast cancer: high dose chemotherapy and bone marrow autotransplants. Ann Int Med 1988;108:570-574.

15 Frei III E, Canellos GP. Dose, a critical factor in cancer chemotherapy. Am J med 1980;69:585-594.

16 Skipper HE. Combination Therapy: some concepts and results. Cancer Chemother Rep 1974;4: 137-145.

17 Santos GW, Tutschka PJ, Brookmeyer R, Saral R, Beschorner WE, Bias WB, Braine HG, Burns WH, Elfenbein $\mathrm{GJ}$, Kaizer $\mathrm{H}$, et al. Marrow transplantation for acute non-lymphocytic leukaemia after treatment with busulfan cyclophosphamide. N Engl J Med 1983;309:1347-1353.

18 Tutschka PJ, Copelan EA, Klein JP. Bone marrow transplantation for leukaemia following a new busulfan and cyclophosphamide regimen. Blood 1987;70:1382-1388.

19 Nevill TJ, Barnett MJ, Klingemann HG, Reece DE, Shepherd JD, Phillips GL. Regimen-related toxicity of a busulfan-cyclophosphamide conditioning regimen in 70 patients undergoing allogeneic bone marrow transplantation. J Clin Oncol 1991;9: 224-1232.

20 Kaplan EL, Meier P. Nonparametric estimations from incomplete observations. J Am Stat Assoc 1958; 53:457-481. 
21 Peters WP, Ross M, Vredenburgh JJ, Meisenberg B, Marks LB, Winer E, Kurtzberg J, Bast RC Jr, Jones R, Shpall E, et al. High-dose chemotherapy and autologous bone marrow support as consolidation after standard-dose adjuvant therapy for high-risk primary breast cancer. J Clin Oncol 1993;11: 132-1143.

22 Peters WP, Berry D, Vredenburgh JJ, et al. Five year follow-up of high-dose combination alkylating agents with $A B M T$ as consolidation after standard-dose CAF for primary breast cancer involving $\geq 10$ axillary lymph nodes (Duke/CALGB 8782). Proc Am Soc Clin Oncol 1995; 14: 316 (abstr 933).

23 de Graaf H, Willemse PH, de Vries EG, Sleijfer DT, Mulder PO, van der Graaf WT, Smit Sibinga CT, van der Ploeg E, Dolsma WV, Mulder NH. Intensive chemotherapy with autologous bone marrow transfusion as primary treatment in women with breast cancer and more than five involved axillary lymph nodes. Eur J Cancer 1994;30A:150-153.

24 Raftopoulos H, Vahdat L, Garrett G, et al. High dose chemotherapy with autologous stem cell rescue in patients with high risk and metastatic breast cancer: The Columbia University Experience. Proc Am Soc Clin Oncol 1996;15:351 (abstr 1029).

25 Hussein A, Plumer M, Vredenburgh J, et al. High-dose chemotherapy (HDC) with Cyclophosphamide (C), Cisplatinum (P), and BCNU (B) (CPB) and autologous bone marrow (ABM) and peripheral blood progenitor cells (PBPCs) for stage II/III breast cancer involving 4-9 axillary lymph nodes. Proc Am Soc Clin Oncol 1996;15:350 (abstr 1026).

26 Tarantolo SR, Reed EC, Rudy E, et al. Prognostic factors for prolonged disease-free survival in patients with high-risk breast cancer treated with high-dose therapy and haematopoietic rescue. Proc Am Soc Clin Oncol 1996;15:349 (abstr 1023).

27 Reed EC, Tarantolo S, Edwards B, et al. Treatment of high-risk breast cancer patients (Pts) with Cyclophosphamide (C), Etoposide (V), Cisplatinum (P) and peripheral blood stem cells (PBSC) in an outpatient (OPT) setting. Proc Am Soc Clin Oncol 1996;15:347 (abstr 1015).

28 Bearman SI, Overmoyer BA, Bolwell BG, et al. High-dose chemotherapy with autologous peripheral blood progenitor cells for primary breast cancer in patients with 4-9 involved axillary lymph nodes. Proc Am Soc Clin Oncol 1996;15:333 (abstr 959).

29 Garcia-Conde J, Sola C, Solano C, et al. High-dose chemotherapy (HDCT) and autologous peripheral stem-cell transplantation (APSCT) after standard chemotherapy (CT) in high-risk breast cancer patients ( $\geq 10$ axillary node involvement after surgery). Proc Am Soc Clin Oncol 1996;15:342 (abstr 994).

30 Crump M, Goss PE, Prince M, Girouard C. Outcome of extensive evaluation before adjuvant therapy in women with breast cancer and 10 or more positive axillary lymph nodes. J Clin Oncol 1996;14:66-69.

31 Klumpp TR, Mangan KF, Glenn LD, Macdonald JS. Phase II pilot study of high-dose Busulfan and CY followed by autologous BM or peripheral blood stem cell transplantation in patients with advanced chemosensitive breast cancer. Bone Marrow Transplant 1993;11:337-339.

32 Kalaycioglu ME, Lichtin AE, Andresen SW, Tuason L, Bolwell BJ. High-dose busulfan and cyclophosphamide followed by autologous bone marrow transplantation and/or peripheral blood progenitor cell rescue for metastatic breast cancer. Am J Clin Oncol (CCT) 1995;18:491-494. 
Addendum chapter 5 



\section{Letter to the editor}

\section{Dear editor,}

In the late nineties of the previous century high dose chemotherapy followed by autologous stem cell transplantation for locally advanced breast cancer attracted a lot of interest. Several uncontrolled trials suggested a benefit for these patients.

Between 1991 and 1995, we performed a phase II trial in 19 breast cancer patients with at least 7 or more involved axillary lymph nodes. ${ }^{1}$ Pretransplant conditioning consisted of high-dose busulphan and cyclophosphamide followed by peripheral blood stem cell support.

Now, with a median follow up of more than 16 years (range 14.3-18.2) after diagnosis, we present the updated results. Two patients encountered early treatment related mortality. Twelve patients relapsed and ultimately died of breast cancer. One patient developed a new contra lateral breast cancer almost 15 years after primary diagnosis and underwent a mastectomy and received again adjuvant systemic therapy. Of importance, even after 9 years three patients developed a relapse and died from the original disease. At this moment the overall event free survival (EFS) is $21 \%$ with an overall survival (OS) of $26 \%$ (see Figure 5A.1). The five patients with continued disease control all had estrogen hormone receptor negative disease. At that time, progesterone receptor and HER2 status was not determined.

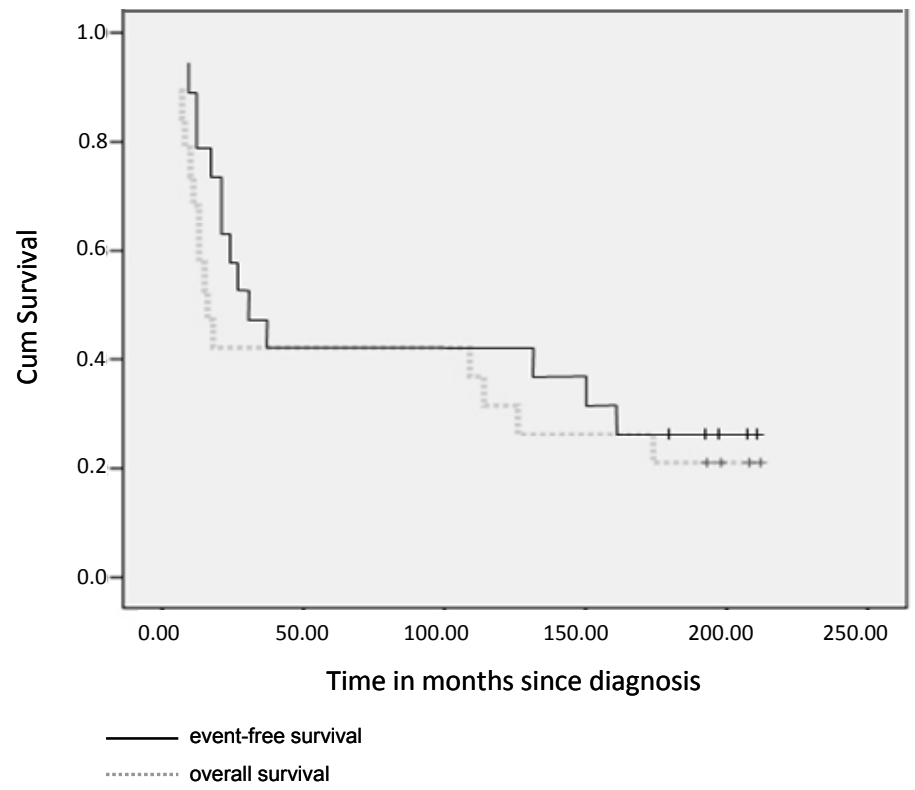

Figure 5A.1 Event-free and overall survival in months 
The West German study group compared, in 403 patients with breast cancer and at least 9 involved lymph nodes, dose-dense conventional chemotherapy with rapidly cycled tandem high-dose chemotherapy plus autologous stem cell support in a prospective randomized trial. ${ }^{2}$ With a median follow-up of 61.7 months, the 5-year EFS $(62 \%$ versus $41 \%$, hazard ratio $=0.60, P=0.004)$ as well as OS $(76 \%$ versus $61 \%$, hazard ratio $=0.58, P=0.007$ ) were significantly better in the high dose chemotherapy arm. Recently they evaluated the prognostic and predictive impact of protein expression of various molecular markers in the study population. Interaction analysis showed that regarding predictive effects, triple negative (ER/PR/HER2 negative) and grade 3 tumors derived most benefit from high dose chemotherapy. They concluded that tandem high dose chemotherapy improved both EFS and OS in locally advanced breast cancer and that this therapy effect may be partly attributable to superior efficacy in the subgroup of grade 3 and/or triple-negative tumors. ${ }^{3}$

To this end, fifteen study groups have reported their results of randomized controlled trials comparing high dose chemotherapy with stem cell autografting versus conventional chemotherapy for women with locally advanced breast cancer. There was a considerable variation among the chemotherapy regimens used in the different trials, but no trial included taxanes as part of the systemic adjuvant treatment. No individual trial, except the West Germany study, could report an overall survival benefit for high dose chemotherapy.

Farquhar et al performed a meta analysis on 13 of these trials. ${ }^{4}$ Six trials had mature data on EFS and OS, and the remaining trials with shorter follow-up reporting estimated survival rates. At three and four years of follow-up there was a statistically significant benefit in EFS for women in the high-dose arm (RR 1.19 and 1.24), which bordered statistical significance at five years (RR 1.06), but which was absent at 6 years of follow-up. It was not possible to demonstrate an OS benefit at any stage of follow up. In fact, there was evidence of harm, with a greater number of treatment related deaths (RR 8.58) and adverse events in the high dose arm. Even with recent developments in supportive care and improvements in the treatment related mortality of high dose chemotherapy, it is not expected that this will result in a sustained benefit in disease-free survival (DFS) over conventional adjuvant systemic therapy, at least not for unselected breast cancer patients.

De Laurentiis conducted a meta-analysis of randomized trials that evaluated the efficacy of incorporating taxanes into anthracycline-based regimens for early breast cancer. ${ }^{5}$ Thirteen studies were included in the meta-analysis ( $n=22,903$ patients). The pooled hazard ratio estimate was $0.83(95 \% \mathrm{Cl}, 0.79$ to $0.87 ; P<0.00001)$ for DFS and $0.85(95 \% \mathrm{Cl}, 0.79$ to $0.91 ; P<0.00001)$ for OS. He concluded that the addition of a taxane to an anthracycline-based regimen improved the DFS and OS of high-risk early breast cancer patients. The DFS benefit was independent of estrogen receptor expression, degree of nodal involvement, type of taxane, age/menopausal status of patient, and administration schedule. 
The reduction in cause-specific mortality from breast cancer that has been demonstrated in almost every Western nation over the last decade is felt to be due, at least in part, to the widespread application of adjuvant systemic therapy. Recent developments incorporating trastuzumab therapy in patients with tumors HER2 gene amplification and aromatase inhibitors in patients with a positive hormone receptor has also improved the outcome in early breast cancer considerably, in addition to the impact of taxanes.

We conclude that if there is any potential benefit of high dose chemotherapy with autografting over conventional chemotherapy, this will be small and may only be present in the triple negative subset of patients. However, for most of the patients combinations including both anthracyclines and taxanes is more easier and safer therapeutic approach. Further studies aimed at optimizing anthracyclines and taxanes in combination, and integrating biologic agents based on biological/molecular tumor factors, seems to be the way forward.

Roy I. Lalisang

Vivianne C.G. Tjan-Heijnen

Harry C. Schouten 
1. Lalisang RI, Hupperets PS, ten Haaft MA, Jansen RL, Schouten HC. High-dose chemotherapy with autologous bone marrow support as consolidation after standard-dose adjuvant therapy in primary breast cancer patients with 7 or more involved axillary lymphnodes. Bone Marrow Transplantation 1998;21:243-247.

2. Nitz UA, Mohrmann S, Fischer J, Lindemann W, Berdel WE, Jackisch C et al. Comparison of rapidly cycled tandem high-dose chemotherapy plus peripheral-blood stem-cell support versus dose-dense conventional chemotherapy for adjuvant treatment of high-risk breast cancer: results of a multicentre phase III trial. Lancet 2005;366:1935-44.

3. Gluz O, Nitz UA, Harbeck N, Ting E, Kates R, Herr A et al. Triple-negative high-risk breast cancer derives particular benefit from dose intensification of adjuvant chemotherapy: results of WSG AM-01 trial. Ann Oncol. 2008;19:861-70.

4. Farquhar CM, Marjoribanks J, Lethaby A, Basser R. High dose chemotherapy for poor prognosis breast cancer: a systematic review and meta-analysis. Cancer Treat Rev. 2007;33:325-37.

5. De Laurentiis M, Cancello G, D'Agostino D, Giuliano M, Giordano A, Montagna E et al. Taxane-based combinations as adjuvant chemotherapy of early breast cancer: a meta-analysis of randomized trials. J Clin Oncol. 2008;26:44-53. 


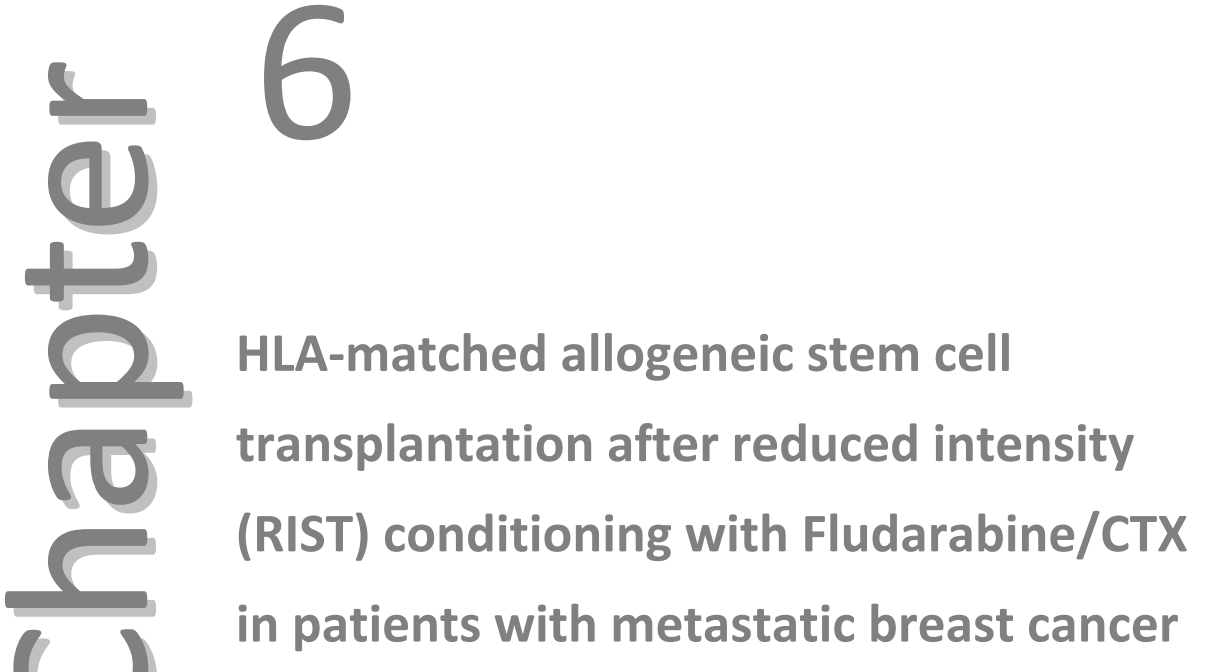

Fleskens AJHM, Lalisang RI, Bos GMJ, van Gelder M, Jansen RLH, Schouten HC Bone Marrow Transplant. 2010;45:464-467. 


\section{Abstract}

Fifteen patients with chemo-sensitive metastatic breast cancer (MBC) underwent reduced intensity (RIST) allogeneic stem cell transplantation (allo-SCT) between 1999 and 2006. Purpose of this single centre study was to evaluate the feasibility, safety and efficacy of this therapeutic approach.

The pre-transplant conditioning regimen consisted of fludarabine $\left(25 \mathrm{mg} / \mathrm{m}^{2}\right.$ at days -5 to- 1$)$ and cyclophosphamide $(60 \mathrm{mg} / \mathrm{kg}$ at days $-2,-1)$. Stem cells were from HLA-matched sibling donors.

The treatment related mortality was $2 / 15$ (13\%). Median progression-free survival (PFS) and overall survival (OS) was 144 days (43-509 days) and 303 days (122-1376 days), respectively. The 1-year PFS was 20\%, and the 1 -year and 2-year OS was $40 \%$ and $20 \%$ respectively. No objective tumor responses were observed, but the relatively long PFS does suggest a graft versus tumor effect.

Although RIST using this cyclophosphamide/fludarabine regimen is feasible, the efficacy in this set of patients was limited. Future clinical trials should be performed to improve the knowledge of mechanisms of anti-tumor effects in breast cancer. 


\section{Introduction}

Conventional allogeneic stem cell transplantation (allo-SCT) represents an accepted curative option for a variety of hematologic malignancies and other disorders such as severe aplastic anemia, hemoglobinopathies and immunodeficiency disorders. ${ }^{1,2}$ Nevertheless, these transplants are complicated by a relatively high treatment related mortality (TRM) caused by toxicity of the myeloablative conditioning, graft-versushost disease (GVHD) and infections. ${ }^{3}$ Therefore this type of transplantation is generally limited to patients younger than $40-50$ years of age with good health status. Since the median age for many solid tumors and hematological malignancies is over 50 years, only a minority of patients may benefit from conventional allo-SCT.

In recent years non-myeloablative or reduced intensity (RIST) conditioning regimens have been developed mostly consisting of purine analogue (Fludarabine) in combination with cytotoxic, immunosuppressive drugs or low-dose total body irradiation (TBI). ${ }^{4}$ Nowadays, this type of pre-transplantation conditioning is used for both solid tumors and hematological malignancies, especially, in patients with advanced age ( $>55$ years), poor disease status, previous intensive treatment, and refractory solid malignancies. Data from recent studies show a decreased treatment related mortality (TRM) and/or less acute GVHD after RIST if compared with conventional myeloablative allo-SCT. ${ }^{5-8}$

In this manuscript we describe the largest single centre experience with RIST allo -SCT in metastatic breast cancer (MBC). Fifteen subsequent patients with $\mathrm{MBC}$ underwent a RIST allo-SCT with a conditioning regimen consisting of fludarabine and cyclophosphamide with proven engraftment, also in solid tumors. ${ }^{9}$ The presented data from one single center are supporting recently published promising data of the European Group for Blood and Marrow Transplant registry (EBMT) and MD Anderson Cancer Centre $^{10}$ and a recent review reporting relatively high response rates and supporting the role of allo-SCT for solid tumors. ${ }^{11}$

\section{Patients and methods}

\section{Patients eligibility}

To be included in this phase II study patients had to have a chemo-sensitive MBC, a (biological) age less than 65 years, minimal tumor load, HLA-identical sibling donor, measurable or evaluable disease, an expected life expectancy $>3$ months and informed consent given. Exclusion criteria were pregnancy or lactating, active infections, other serious underlying condition, and concurrent treatment with other experimental agents. 


\section{Treatment schedule}

Stem cells were obtained from HLA-identical related donors by leukapheresis after stimulation with Filgrastim $(10 \mu \mathrm{g} / \mathrm{kg})$. The conditioning regimen consisted of fludarabine $25 \mathrm{mg} / \mathrm{m}^{2}$ at days $-5,-4,-3,-2$ and -1 and cyclophosphamide $60 \mathrm{mg} / \mathrm{kg}$ at days -2 and -1 . Subsequently, all patients were transplanted with unmanipulated peripheral blood stem cells (PBSC). We aimed for at least $4 \times 10^{6} / \mathrm{kg}$ CD34 positive cells. Prophylaxis for GVHD consisted of standard cyclosporine-A and standard methotrexate. $^{12}$

After relapse, progression or in the case of incomplete chimerism at 30 days after transplantation ( $<80 \%$ donor cells) cyclosporine-A was discontinued earlier. In case of no improvement after one month patients were treated with donor lymphocytes infusions (DLI) $1 \times 10^{7} \mathrm{CD} 3+/ \mathrm{kg}$ followed by, if no improvement, monthly increasing numbers of T lymphocytes ( $5 \times 10^{7} \mathrm{CD} 3+/ \mathrm{kg}$ and $\left.10 \times 10^{7} \mathrm{CD} 3+/ \mathrm{kg}\right)$.

\section{Evaluations and definitions}

Diagnosis and clinical grading of acute and chronic GVHD were performed according to established criteria. ${ }^{13,14}$ Donor-host chimerism levels for sex-mismatched SCT were analyzed by fluorescent in situ hybridization (FISH) with probes specific for the $\mathrm{X}$ and $Y$ chromosome. For recipients of sex-matched SCT, chimerism was assessed using polymerase chain reaction-based amplification of short tandem repeat polymorphism (STRP) sequences unique to donors and hosts. Treatment related mortality was defined as death if there was at time of death no evidence of disease relapse or progression.

\section{Supportive care}

Infection prophylaxis, supportive care and follow-up were carried out according to standard local policy.

\section{Objectives}

The primary objective of this prospective study was whether RIST allo-SCT could produce a graft versus tumor (GVT) effect in metastatic breast cancer, evidenced by tumor response after post-transplant immune manipulation, and improved progression-free survival (PFS) and overall survival (OS). Other study end points were treatment related mortality and GVHD. Data were included till July 2008. PFS and OS were compiled using the Kaplan-Meier analysis.

The number of patients to be included in this phase II study was 20 , however, due to slow accrual and changing oncology practices the study was closed after the inclusion of 15 patients. 


\section{Results}

Between March 1999 and October 2006, 15 patients with MBC, fulfilling the entry criteria, were treated with a RIST conditioning regimen followed by an allo-SCT using HLA identical sibling donors. The basic characteristics of the patients are presented in Table 6.1. The median age was 49.5 years (range $39.7-60.8$ years). All patients had a WHO performance status $0-1$ at admission for transplantation. The median time interval from the initial diagnosis of breast cancer till transplant was 6 years (range 0.6 -20.3 years). All patients were extensively pre-treated and all had at least undergone one palliative chemotherapy regimen for metastatic disease.

Table 6.1 Patient characteristics.

\begin{tabular}{rcccc}
\hline UPN & Age at BMT & Interval Diagnosis BMT (yrs) & PFS (days) & Survival (days) \\
\hline 73 & 51,0 & 7,4 & 138 & 138 \\
75 & 43,7 & 6,0 & 71 & 413 \\
76 & 50,4 & 7,0 & 74 & 129 \\
82 & 45,9 & 5,9 & 105 & 303 \\
84 & 60,8 & 0,6 & 312 & 1370 \\
101 & 49,7 & 4,1 & 509 & 1376 \\
119 & 55,7 & 20,3 & 233 & 586 \\
126 & 47,0 & 2,5 & 90 & 228 \\
138 & 59,2 & 12,5 & 43 & 123 \\
142 & 59,8 & 5,3 & 461 & 478 \\
145 & 47,4 & 9,0 & 218 & 263 \\
191 & 48,9 & 3,1 & 144 & 144 \\
196 & 43,8 & 8,5 & 350 & 401 \\
208 & 39,7 & 3,6 & 382 & 704 \\
226 & 49,5 & 13,8 & 100 & 122 \\
\hline
\end{tabular}

The median number of $\mathrm{CD}_{3} 4^{+}$cells harvested from HLA-identical sibling donors by leukapheresis was $4.4 \times 10^{6} \mathrm{CD}^{+}{ }^{+}$cells/kg of the recipient (range 1.5-15.5).

All patients ultimately died: two out of 15 patients (13\% TRM) died without proven tumor progression, 138 and 144 days post-transplant, respectively. These two patients died of infectious complications. All other died of disease progression. The median PFS and OS was 144 days (43-509 days) and 303 days (122-1376 days), respectively (see Figures 6.1 and 6.2). The 1-year PFS was 20\%, and the 1-, 2- and 3 -year OS was $40 \%, 20 \%$ and $13 \%$, respectively. 


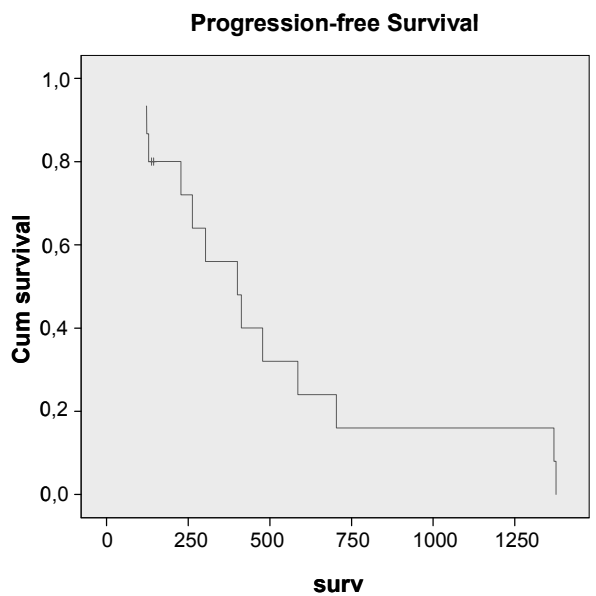

Figure 6.1 Progression-free survival in 15 patients with metastatic breast cancer after reduced intensity transplantation

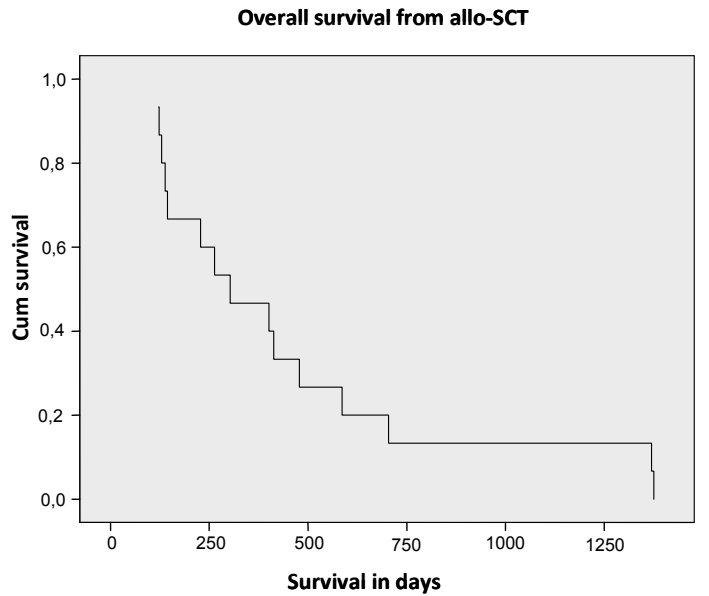

Figure 6.2 Overall survival in 15 patients with metastatic breast cancer after reduced intensity transplantation.

The occurrence of acute GvHD was very low, grade 1-2 and 3-4 was observed in one patient each (upn 142 and 145). Also limited and extensive chronic GvHD occurred infrequently, each in one patient (upn 142 and 145). These two patients had a PFS and OS close to the median.

Ten of the 15 (67\%) patients received DLI: three patients once, two patients twice, three patients three times, and two patients four times. No objective tumor responses were observed. In one patient a tumor marker decline was observed. After initial progression she responded temporarily after DLI infusions, as measured with CA 15-3 (see Figure 6.3). 


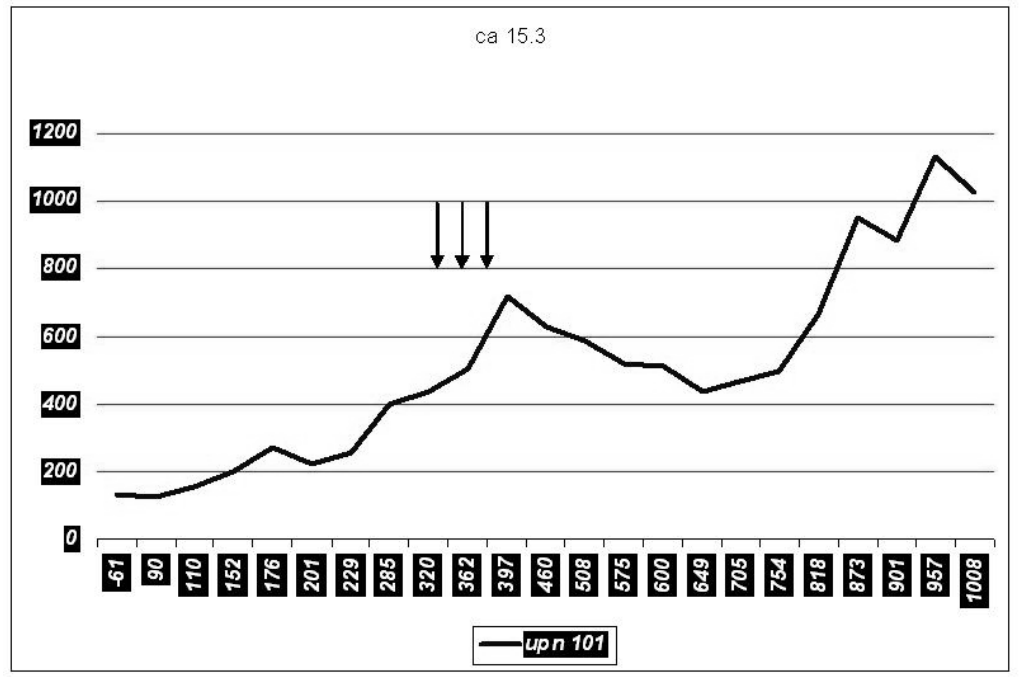

Figure 6.3 One patient (upn 101) with metastatic breast cancer, progressing after RIST, with a temporary tumor marker response to increasing doses of DLI.

\section{Discussion}

Here, we describe the results of a phase II study applying RIST allo-transplantation in $15 \mathrm{MBC}$ patients after a fludarabine and cyclophoshamide conditioning regimen. We conclude from this study that the TRM was relatively low (13\%), the GvHD limited, and no objective tumor response was observed other than a temporary CA15-3 response after DLI.

To interpret our data more carefully, comparative data should be available, which is not the case in this phase II study. However, the absence of major responses and only one temporary tumor marker CA 15-3 decline after DLI suggests that the anti-tumor effect in this group of patients with MBC is limited. Also patients with acute or chronic GVHD did not appear to do better.

Previous publications, with generally smaller numbers than this study, were mainly single center studies with more or less promising results. Carella et al. ${ }^{15}$ reported an overall response rate of $24 \%$, after a tandem approach, consisting of high-dose chemotherapy with autologous SCT to achieve maximum tumor reduction before proceeding to allo-SCT. Bishop et al. ${ }^{16}$ observed that objective tumor regressions in $33 \%$ of the patients were attributable to allogeneic lymphocyte infusions. Ueno et al. ${ }^{17}$ 
treated 10 patients with MBC observing 2 CR's and one minimal response. Bregni et al. ${ }^{18}$ observed a partial remission in 2 (33\%) patients.

Recently an overview of international collaboration was published. ${ }^{10,11}$ In these studies response rates attributable to a GVT effect were $16-37 \%$, concluding that a GVT effect exists in MBC. Ueno reported that in myeloablative conditioning regimen, the development of acute GVHD was associated with an increased risk of treatment failure (progression, relapse or death). However, in women treated with RIST, there was a decreased risk of treatment failure associated with the development of acute GVHD. In his report the cumulative incidence of grade II-IV acute GVHD at 100 days was $44 \%$ after myeloablative conditioning and $34 \%$ after RIST. The cumulative incidence of chronic GVHD at 1 year was much higher in the myeloablative group (36\%) than in the RIST group (8\%). ${ }^{10}$

In MBC the median PFS and OS with second-line and higher lines of chemotherapy is in the range of 3-4 months and 8-12 months, respectively. ${ }^{18}$

In our heavily pretreated group the median PFS was almost 5 months, which despite the absence of an objective tumor response, does suggest a GVT effect.

We conclude that routine application of non-myeloablative transplantation for MBC may lead to small benefit in PFS.

The anti-tumor effect after allogeneic transplantation relies more or less on a $\mathrm{T}$ cell effect. We feel that this effect is limited. We cannot exclude that a different approach exploiting a NK-cell effect, like in haplo-identical transplants, would result in a better outcome. ${ }^{19,20}$

Future clinical trials should be performed to improve the knowledge of mechanisms of anti-tumor effects in breast cancer. ${ }^{10,11}$ 


\section{References}

1. Thomas E, Storb R, Clift RA, Fefer A, Johnson FL, Neiman PE, Lerner KG, Glucksberg H, Buckner CD. Bone-marrow transplantation (first of two parts). N Engl J Med 1975;292:832843.

2. Thomas ED, Storb R, Clift RA, Fefer A, Johnson L, Neiman PE, Lerner KG, Glucksberg H, Buckner CD. Bone-marrow transplantation (second of two parts). N Engl J Med 1975;292:895-902.

3. Huugen D, Schouten HC, Bos GM. Advantages and limitations of (non-)myeloablative allogeneic stem cell transplantation. Neth. J. Med. 2002;60:162-169.

4. Buffart TE, Janssen JJWM, Huijgens PC. Reduced-intensity conditioning regimens in malignant haematological diseases. Neth J Med 2005;63:43-51.

5. Mielcarek M, Martin PJ, Leisenring W, Flowers ME, Maloney DG, Sandmaier BM, Maris MB, Storb R. Graft-versus-host disease after nonmyeloablative versus conventional hematopoietic stem cell transplantation. Blood 2003;102:756-762.

6. Couriel DR, Saliba RM, Giralt S, Khouri I, Andersson B, de Lima M, Hosing C, Anderlini P, Donato M, Cleary K, Gajewski J, Neumann J, Ippoliti C, Rondon G, Cohen A, Champlin R. Acute and chronic graftversus-host disease after ablative and nonmyeloablative conditioning for allogeneic hematopoietic transplantation. Biol Blood Marrow Transplant 2004;10:178-185.

7. Sorror ML, Maris MB, Storer B, Sandmaier BM, Diaconescu R, Flowers C, Maloney DG, Storb R. Comparing morbidity and mortality of HLA-matched unrelated donor hematopoietic cell transplantation after nonmyeloablative and myeloablative conditioning: influence of pretransplantation comorbidities. Blood 2004;104:961-968.

8. Alyea EP, Kim HT, Ho V, Cutler C, Gribben J, DeAngelo DJ, Lee SJ, Windawi S, Ritz J, Stone RM, Antin $\mathrm{JH}$, Soiffer RJ. Comparative outcome of nonmyeloablative and myeloablative allogeneic hematopoietic cell transplantation for patients older than 50 years of age. Blood 2005;105: 1810-1814.

9. Childs RW, Clave E, Tisdale J, Plante M, Hensel N, Barrett J. Successful Treatment of Metastatic Renal Cell Carcinoma With a Nonmyeloablative Allogeneic Peripheral-Blood Progenitor-Cell Transplant: Evidence for a Graft-Versus-Tumor Effect. J Clin Oncol 1999;17:2044-2049.

10. Ueno NT, Rizzo JD, Demirer T, Cheng YC, Hegenbart U, Zhang MJ, Bregni M, Carella A, Blaise D, Bashey A, Bitran JD, Bolwell BJ, Elfenbein GJ, Fields KK, Freytes CO, Gale RP, Lazarus HM, Champlin RE, Stiff PJ, Niederwieser D. Allogeneic hematopoietic cell transplantation for metastatic breast cancer. Bone Marrow Transplant 2008;41:537-545.

11. Demirer T, Barkholt L, Blaise D, Pedrazzoli P, Aglietta M, Carella AM, Bay JO, Arpaci F, Rosti G, Gurman G, Niederwieser D, Bregni M; EBMT Solid Tumors Working Party. Transplantation of allogeneic hematopoietic stem cells: an emerging treatment modality for solid tumors. Nature clinical practice. Oncology 2008;5:256-267.

12. Storb R, Deeg HJ, Farewell V, Doney K, Appelbaum F, Beatty P, Bensinger W, Buckner CD, Clift R, Hansen J, et al. Marrow transplantation for severe aplastic anemia: methotrexate alone compared with a combination of methotrexate and cyclosporine for prevention of acute graft-versus-host disease. Blood 1986;68:119-125.

13. Glucksberg H, Storb R, Fefer A, Buckner CD, Neiman PE, Clift RA, Lerner KG, Thomas ED. Clinical manifestations of graft-versus-host disease in human recipients of marrow from HL-A-matched sibling donors. Transplantation 1974;18:295-304.

14. Sullivan KM, Shulman HM, Storb R, Weiden PL, Witherspoon RP, McDonald GB, Schubert MM, Atkinson K, Thomas ED. Chronic graft-versus-host disease in 52 patients: adverse natural course and successful treatment with combination immunosuppression. Blood 1981;57:267-276.

15. Carella AM, Beltrami G, Corsetti MT, Nati S, Musto P, Scalzulli P, Gonella R, Ballestrero A, Patrone F. Reduced intensity conditioning for allograft after cytoreductive autograft in metastatic breast cancer. Lancet 2005;366:318-320.

16. Bishop MR, Fowler DH, Marchigiani D, Castro K, Kasten-Sportes C, Steinberg SM, Gea-Banacloche JC, Dean R, Chow CK, Carter C, Read EJ, Leitman S, Gress R. Allogeneic lymphocytes induce tumor regression of advanced metastatic breast cancer. J Clin Oncol 2004;22:3886-3892. 
17. Ueno NT, Cheng YC, Rondón G, Tannir NM, Gajewski JL, Couriel DR, Hosing C, de Lima MJ, Anderlini P, Khouri IF, Booser DJ, Hortobagyi GN, Pagliaro LC, Jonasch E, Giralt SA, Champlin RE. Rapid induction of complete donor chimerism by the use of a reduced-intensity conditioning regimen composed of fludarabine and melphalan in allogeneic stem cell transplantation for metastatic solid tumors. Blood 2003;102:3829-3836.

18. Seidman AD, O'Shaughnessy J, Misset J-L. Single-Agent Capecitabine: A Reference Treatment for Taxane-Pretreated Metastatic Breast Cancer? Oncologist 2002;7:20-28.

19. Bregni M, Dodero A, Peccatori J, Pescarollo A, Bernardi M, Sassi I, Voena C, Zaniboni A, Bordignon C, Corradini $P$. Nonmyeloablative conditioning followed by hematopoietic cell allografting and donor lymphocyte infusions for patients with metastatic renal and breast cancer. Blood 2002;99:4234-4236.

20. Ruggeri L, Capanni M, Urbani E, Perruccio K, Shlomchik WD, Tosti A, Posati S, Rogaia D, Frassoni F, Aversa F, Martelli MF, Velardi A. Effectiveness of donor natural killer cell alloreactivity in mismatched hematopoietic transplants. Science 2002;295:2097-2100. 


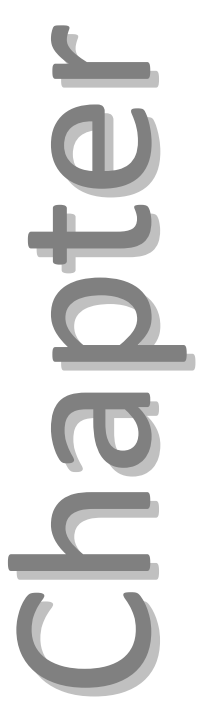

Summary, conclusions and future perspectives 



\section{Summary, conclusions and future perspectives}

Breast cancer is the most common female cancer type in the western world, the most common cause of cancer death in women, and the main cause of death in women aged between 45 to 55 years. In the early and locally advanced disease setting cure may be achieved by adding systemic therapy to locoregional therapy. However, as soon as disease has spread beyond nearby localized lymph nodes, the disease is considered not curable anymore. Although the majority of patients with metastatic breast cancer will experience an initial response or stabilization of the disease on various combination chemotherapy regimens, many relapses occur within one year and the median overall survival after start of treatment is limited to on average two to three years.

The aim of dose intensification of chemotherapy is to increase the dose size and/or dose frequency beyond the limit of normal bone marrow tissue tolerance, with the intention to maximize antitumor efficacy. Dose intensity, dose size and cumulative dose may each have important but different effects on outcome. According to the analysis of Goldie and Coldman the main effect of a high dose intensity is a more rapid and effective eradication of sensitive tumor cells, with the dose size the most important factor in reducing the chance of developing resistant cells. ${ }^{1}$ Norton showed that a Gompertzian growth model precisely fitted in the growth curves of breast cancer. ${ }^{2}$ In this model, when a patient with advanced breast cancer is treated and the tumor mass is large, its growth fraction is low and the fraction of cells killed is low. Shortening of intervals ("dose-dense chemotherapy") may be important to overcome this cytokinetic resistance of tumors, by killing chemosensitive cells and recruiting regrowth of dormant cells, which will be killed by the subsequent cycle.

Chemotherapy intensification has met only limited success, mainly due to profound myelosuppression. Hematopoietic growth factors, and particularly Granulocyte Colony Stimulating Factor (G-CSF), offer an opportunity to overcome this problem. ${ }^{3}$ The addition of G-CSF may not only reduce the incidence of febrile neutropenia, but also supports an increase in dose-intensity of cytotoxic agents by allowing a higher dose of chemotherapy per course (dose-escalation) or by allowing a shortening of interval between courses (dose-densification). Both approaches may lead to a higher doseintensity, but their biological effect and thereby clinical relevance may be quite different as has been pointed out by Henderson in his review on the dose-intensity phenomenon in breast cancer. ${ }^{4}$ The relative merits of these two approaches have not been studied systematically.

In advanced breast cancer anthracycline non-taxane combination regimens as firstline systemic therapy result in a $30 \%$ to $50 \%$ overall response rate, with a complete response rate of $5 \%$ to $10 \%$ and a median progression-free survival of four to eight 
months. Epirubicin is a synthetic doxorubicin analogue, with a similar activity but decreased toxicity profile, in particular less cardiotoxicity. ${ }^{5}$

In Chapter $\mathbf{2}$ the results of a comparative study of dose escalation versus interval reduction to obtain the maximal dose intensity of epirubicin and cyclophosphamide with G-CSF in advanced breast cancer is described. The second aim was to assess the safety profiles of these intensified schedules.

In this multicentre study, 49 advanced breast cancer patients were treated with daily G-CSF injections and either increasing doses of epirubicin and cyclophosphamide with fixed intervals (arm 1) or progressively shorter intervals with fixed doses of epirubicin and cyclophosphamide (arm 2). A cohort of at least 6 patients was studied at each interval/dose. A more intensified interval/dose was given if less than $50 \%$ of patients encountered a dose intensity limiting criterium in the first 3 courses.

In $\operatorname{arm~1,~epirubicin/cyclophosphamide~} 140 / 800 \mathrm{mg} / \mathrm{m}^{2}$ q 21 days was too toxic. Subsequently epirubicin/cyclophosphamide $120 / 700 \mathrm{mg} / \mathrm{m}^{2}$ was tested with 2 out of 10 patients encountering a dose limiting toxicity. All initial dose limiting toxicities consisted of febrile neutropenia. In arm 2 epirubicin/cyclophosphamide $75 / 500 \mathrm{mg} / \mathrm{m}^{2}$ could be administered safely with 14 and 12 days intervals. In the 10 days interval 8 out of 12 patients completed the first 3 cycles without a dose limiting toxicity. In the 8 days interval 7 out of 8 patients encountered a dose limiting toxicity. Incomplete neutrophil recovery, and to a lesser extent stomatitis, was dose limiting. A clinically asymptomatic cardiotoxicity was observed in $21 \%$ of patients treated with the shorter intervals, that appeared however reversible with longer follow-up.

In combination with G-CSF, epirubicin/cyclophosphamide $120 / 700 \mathrm{mg} / \mathrm{m}^{2}$ q 21 days was feasible, with a projected dose intensity of $40 \mathrm{mg} / \mathrm{m} 2 /$ week and $233 \mathrm{mg} / \mathrm{m}^{2}$ / week, respectively. Epirubicin/cyclophosphamide $75 / 500 \mathrm{mg} / \mathrm{m}^{2}$ could be administered safely every 10 days, allowing a superior projected dose intensity of $52.5 \mathrm{mg} / \mathrm{m}^{2} /$ week and $350 \mathrm{mg} / \mathrm{m}^{2} /$ week, respectively.

In conclusion, with the addition of G-CSF shortening of intervals with standard doses of chemotherapy seems to be a more effective method of dose intensification, when compared to increasing doses of chemotherapy at fixed intervals.

Apart from anthracyclines, taxanes belong to the most active single agents in advanced breast cancer. Paclitaxel is highly active and lacks cross-resistance with other drugs commonly used in breast cancer treatment. ${ }^{6,7}$ The combination of paclitaxel and doxorubicin showed promising response rates of $83 \%$ to $95 \%$ in clinical phase I and II studies. The superiority of an anthracycline-taxane combination was subsequently confirmed in five randomized phase III studies with response rates of $55 \%$ to $68 \%$ and a (small) gain in progression-free survival. ${ }^{8-12}$ Two studies showed a significant improvement in overall survival, but at the cost of considerable increase in treatment related toxicity, mainly febrile neutropenia, infections and cardiac toxicity. 
Chapter 3 describes a study in metastatic breast cancer with the aim of increasing the dose-intensity of the epirubicin and paclitaxel combination by shortening cycle time. The objective was to define the shortest feasible chemotherapy interval and to assess the safety profile of this dose dense approach, supported by G-CSF.

We treated thirty-six patients with advanced breast cancer in a multicenter phase $\mathrm{I} / \mathrm{II}$ study. The treatment regimen consisted of epirubicin $75 \mathrm{mg} / \mathrm{m} 2$ followed by paclitaxel $135 \mathrm{mg} / \mathrm{m}^{2}$ (3-hours) in combination with G-CSF $(5 \mu \mathrm{g} / \mathrm{kg})$. At least 6 patients were treated in each cohort and were evaluated over the first 3 cycles.

Starting at an interval of 14 days, in subsequent cohorts of patients the interval could be shortened to 10 days. The 8-days interval was not feasible mainly due to incomplete neutrophil recovery at the day of the next scheduled cycle. In the cohort of 10 days interval it was even feasible to increase the paclitaxel dose to $175 \mathrm{mg} / \mathrm{m}^{2}$. The treatment related toxicity was relatively mild. Nine out 36 patients developed a dose limiting toxicities in the first 3 cycles. Initial dose limiting toxicities were incomplete hematological recovery at the day of scheduled cycle in five, febrile neutropenia in one and non-hematological in the remaining three patients, respectively. No cumulative myelosuppression was observed over at least 3 consecutive cycles. In our study already after three short interval cycles a response rate of $53 \%$ was observed.

In conclusion, with the addition of G-CSF, shortening of intervals of chemotherapy seems to be a feasible method of dose intensification, allowing a dose intensity of 52 $\mathrm{mg} / \mathrm{m}^{2} /$ week for epirubicin in combination with $122 \mathrm{mg} / \mathrm{m}^{2} /$ week of paclitaxel, respectively.

The efficacy and clinical relevance of this approach, have to be investigated in a phase II study.

The two approaches of dose-intensification, either escalation or densification, regarding the combination of epirubicin and paclitaxel, have been investigated in Chapter 4. This multicentre randomised phase II study investigated epirubicin $110 \mathrm{mg} / \mathrm{m}^{2}$ combined with paclitaxel $200 \mathrm{mg} / \mathrm{m}^{2}$ every 21 days and epirubicine $75 \mathrm{mg} / \mathrm{m}^{2}$ combined with paclitaxel $175 \mathrm{mg} / \mathrm{m}^{2}$ every 10 days, both supported with GCSF. Patients with advanced breast cancer and without prior palliative chemotherapy were scheduled for 6 cycles.

One hundred and six patients were evaluable for toxicity and 101 patients for response. Grade $\geq 3$ toxicities occurred in $39 \%$ of patients in the dose-escalated arm and in $29 \%$ of patients in the dose-dense arm, consisting mainly of febrile neutropenia, thrombocytopenia, neurotoxicity. A higher incidence of mainly asymptomatic cardiac toxicity was also observed in the dose-escalated arm (16\% vs $8 \%$ ), likely associated with the higher cumulative dose of epirubicin in this arm, but also the interaction between epirubicin and paclitaxel may have played a role. The median delivered cumulative doses for epirubicin/paclitaxel were 656/1194 mg/m² and $448 / 1045 \mathrm{mg} / \mathrm{m}^{2}$, treatment durations were 126 and 61 days, and delivered dose 
intensities for epirubicin/paclitaxel were $36 / 67$ and $51 / 120 \mathrm{mg} / \mathrm{m}^{2} /$ week for the doseescalated en dose-dense arm, respectively. Both arms appeared to be very effective with response rates of $70 \%$ and more. Already after three cycles of chemotherapy the response rates were $51 \%$ for the dose-dense regime (after 1 month of treatment) and $55 \%$ for the dose-escalated regime (after 2 months of treatment), respectively. Despite the almost halved treatment duration in the dose-dense arm and a lower cumulative chemotherapy dose, the progression-free survival (6 and 7 months, respectively) seemed to be quite comparable for both treatment arms. For the dosedense regime the treatment-free period was five months, whereas for the doseescalated regime this was only two months.

The dose-dense regime seemed to be the preferred schedule, because of less side effects and with a comparable time-to-progression this shorter treatment schedule resulted in a substantial longer off-treatment period. We feel that in breast cancer the concept of dose-density warrants further testing.

In early stage breast cancer, adjuvant systemic therapy demonstrated a modest, but consistent improvement in long term disease-free and overall survival. Attempts to further increasing the dose of chemotherapy are limited mainly due to profound myelosuppression, even with the support of hematopoietic growth factors. Autologous stem cell transplantation offers an opportunity to overcome this problem, but whether this will lead to better results in terms of disease free en overall survival was at the time unclear.

In Chapter $\mathbf{5}$ we tested the concept of high dose chemotherapy with autologous bone marrow support as consolidation after standard-dose adjuvant therapy in primary breast cancer patients with 7 or more involved axillary lymph nodes.

In the period from November 1991 till October 1995, 19 patients with at least 7 or more involved axillary lymph nodes underwent 4 cycles of standard adjuvant chemotherapy, followed by high dose chemotherapy (busulfan and cyclophosphamide) and autologous bone marrow support. The median age was 41 years, the median number of involved lymph nodes was 11 (range 7-29) and the tumors were estrogen-receptor positive in 9 patients.

With a relatively short median follow-up of 45 months we encountered two patients with a treatment related mortality, and nine patients with relapsed disease. The median event-free and overall survival was 16 months and 27 months, respectively. A recent update after a follow-up of more than 16 years, showed that 12 of the 19 patients have relapsed and ultimately died, resulting in a overall event-free and overall survival of $26 \%$.

High-dose treatment with autologous bone marrow support in high-risk locally advanced breast cancer patients is a toxic regime and does not seem to improve survival, at least not for unselected breast cancer patients. 
Autologous bone marrow transplantation as a method to support high-dose chemotherapy is one possible way to go. Allogeneic stem cell transplantation may be an alternative approach.

Conventional allogeneic stem cell transplantation is an accepted curative option for a variety of hematologic malignancies and other disorders. However, complicated by a relatively high treatment related mortality caused by toxicity of the myeloablative conditioning, graft-versus-host disease and infections, the indication is generally limited to patients younger than 40-50 years of age with good health status. Since the median age for many solid tumors and hematological malignancies is over 50 years, only a minority of patients may benefit from conventional allogeneic stem cell transplantation. In recent years non-myeloablative or 'reduced intensity conditioning' regimens have been developed with allogeneic stem cell transplantation. The goal of this approach is to obtain tumor cell kill from T-cell effects, so called graft-versustumor-effect, and not primarily from delivered chemotherapy effects. This type of pre-transplantation conditioning may be interesting for both solid tumors and hematological malignancies. An overview of international collaboration reported response rates attributable to a graft-versus-tumor effect of $16 \%$ to $37 \%$, concluding that a graft-versus-tumor-effect exists, also in metastatic breast cancer. ${ }^{13,14}$

Chapter 6 provides the results of a phase II study of HLA-matched allogeneic stem cell transplantation after reduced intensity conditioning with fludarabine/cyclophosphamide in 15 patients with metastatic breast cancer. Purpose of this single centre study was to evaluate the feasibility, safety and efficacy of this therapeutic approach. The pre-transplant conditioning regimen consisted of fludarabine $\left(25 \mathrm{mg} / \mathrm{m}^{2}\right.$ at days -5 to-1) and cyclophosphamide (60 mg/kg at days $-2,-1)$. Stem cells were from HLAmatched sibling donors. The treatment related mortality was 2 out of 15 (13\%). Median progression-free survival and overall survival was 144 days (43-509 days) and 303 days (122-1376 days), respectively. The one year progression free survival was $20 \%$, and the one year and two years overall survival was $40 \%$ and $20 \%$, respectively. No objective tumor responses were observed.

Although 'reduced intensity conditioning' allogeneic stem cell transplantation is feasible, the efficacy in this set of patients was limited. Future clinical trials should be performed to improve the knowledge of mechanisms of anti-tumor effects in breast cancer.

\section{In summary}

We have shown that in the advanced breast cancer setting dose-densification of taxane and nontaxane regimens compared to dose-escalation results in a higher chemotherapy dose-intensity and a lower cumulative dose. Moreover, there is a suggestion of increased efficacy and improved toxicity profile for the dose-dense regimens. Others have also shown that dose-dense chemotherapy was superior to 
standard-dose chemotherapy. ${ }^{15}$ Due to the limited data, the concept of dosedensification with only modest increase in dose-intensity is, however, still debated and not widespread used. The only exception is the administration of paclitaxel. Both in the adjuvant and metastatic setting it was shown that paclitaxel given weekly was superior to a 3-weekly regimen in terms of response rate and survival. ${ }^{16,17}$

Regarding the value of high dose chemotherapy with autologous bone marrow support as consolidation after standard-dose adjuvant therapy in primary breast cancer, we observed a long term survival rate probably not superior to the ones reported in literature obtained by conventional chemotherapy. In a meta analysis on 13 of these trials there was no overall survival benefit compared with standard chemotherapy. ${ }^{18}$ In fact, there was evidence of harm, with a greater number of treatment related deaths.

As an alternative for high dose chemotherapy with autologous bone marrow support, we tested the strategy of 'reduced intensity conditioning' with allogeneic stem cell transplantation. Although this strategy was feasible, the efficacy was limited.

\section{Current standards}

A meta-analysis of survival data from 128 randomized trials concluded that the gains in absolute survival from anthracyclines, taxanes, novel nontaxanes such as capecitabine and gemcitabine, either as monotherapy or combined therapy, ranged from 4.2 to 12.5 months for a patient with an anticipated survival of one year treated with the reference standard alone. ${ }^{19}$

Recent trials indicate that combinations including both anthracyclines and taxanes in the adjuvant setting may be superior to the older regimens. ${ }^{20}$

\section{Future perspectives}

Major developments in the field of systemic therapy for breast cancer have been made during the last decade due to developments in the field of molecular oncology. For instance, the introduction of third generation aromatase inhibitors with increasing insights in endocrine pathways and working mechanisms have changed the endocrine treatment field dramatically. But, even more important was the discovery of the receptors of the HER-family, with the HER2 at present being the most exciting target in breast cancer. Approximately 20 percent of breast cancers have amplified levels of the proto-oncogene HER2. Amplified/overexpressed HER2 predicts for response to therapies that target HER2, such as the humanized monoclonal antibody trastuzumab and the small molecule tyrosine kinase inhibitor lapatinib. ${ }^{21}$ Other developments in the field of targeted therapies include the Vascular Endothelial Growth Factor (VEGF)related therapy by antibodies or tyrosine kinase inhibitors and the Poly ADP Ribose Polymerase (PARP) inhibitors, specifically in the triple negative patient groups.

The identification of these molecular pathways may in due time also improve patient selection for classical chemotherapeutic agents such as anthracyclines and taxanes. If 
indeed patients with a chemosensitive tumor can be identified by biological parameters, one may hypothesize that even small chemotherapy administration modifications may have a significant impact on outcome. So, the increasing insights in molecular pathways may facilitate the study on chemotherapy dose-densification in selected patients. 


\section{References}

1. Goldie JH, Coldman AJ. A mathematical model for relating the drug sensitivity of tumour to the spontaneous mutation rate. Cancer Treat Rep 1979;63:1727-1733.

2. Norton LA. A Gompertzian model of human breast cancer growth. Cancer Res 1988;48:7067-7071.

3. Bronchud MH, Howell A, Crowther D, Hopwood P, Souza L, Dexter TM. The use of granulocyte colonystimulating factor to increase the intensity of treatment with doxorubicin in patients with advanced breast and ovarian cancer. Br J Cancer 1989;60:121-125.

4. Henderson IC, Hayes DF, Gelman R. Dose-response in the treatment of breast cancer. J Clin Oncol 1988;6:1501-1516.

5. Jain KK, Casper ES, Geller NL, Hakes TB, Kaufman RJ, Currie V, Schwartz W, Cassidy C, Petroni GR, Young $\mathrm{CW}$, et al. A prospective randomized comparison of Epirubicin and Doxorubicin in patients with advanced breast cancer. J Clin Oncol 1985;3:818-826.

6. Holmes FA, Walters RS, Theriault RL, Forman AD, Newton LK, Raber MN, Buzdar AU, Frye DK, Hortobagyi GN. Phase II trial of Taxol, an active drug in the treatment of metastatic breast cancer. J Natl Cancer Inst 1991; 83: 1797-1805.

7. Reichman BS, Seidman AD, Crown JP, Heelan R, Hakes TB, Lebwohl DE, Gilewski TA, Surbone A, Currie $V$, Hudis CA, et al. Paclitaxel and Recombinant human granulocyte colony-stimulating factor as initial chemotherapy for metastatic breast cancer. J Clin Oncol 1993;11:1943-1951.

8. Jassem J, Pieńkowski T, Płuzańska A, Jelic S, Gorbunova V, Mrsic-Krmpotic Z, Berzins J, Nagykalnai T, Wigler N, Renard J, Munier S, Weil C; Central \& Eastern Europe and Israel Pacitaxel Breast Cancer Study Group. Doxorubicin and paclitaxel versus fluorouracil, doxorubicin, and cyclophosphamide as first-line therapy for women with metastatic breast cancer: final results of a randomized phase III multicenter trial. J Clin Oncol 2001;19:1707-1715.

9. Bontenbal M, Creemers GJ, Braun HJ, de Boer AC, Janssen JT, Leys RB, Ruit JB, Goey SH, van der Velden PC, Kerkhofs LG, Schothorst KL, Schmitz PI, Bokma HJ, Verweij J, Seynaeve C; Dutch Community Setting Trial for the Clinical Trial Group. Phase II to III study comparing doxorubicin and docetaxel with fluorouracil, doxorubicin, and cyclophosphamide as first-line chemotherapy in patients with metastatic breast cancer: results of a Dutch Community Setting Trial for the Clinical Trial Group of the Comprehensive Cancer Centre. J Clin Oncol 2005;23:7081-7088.

10. Biganzoli L, Cufer T, Bruning P, Coleman R, Duchateau L, Calvert AH, Gamucci T, Twelves C, Fargeot $P$, Epelbaum R, Lohrisch C, Piccart MJ. Doxorubicin and paclitaxel versus doxorubicin and cyclophosphamide as first-line chemotherapy in metastatic breast cancer: The European Organization for Research and Treatment of Cancer 10961 Multicenter Phase III Trial. J Clin Oncol 2002;20: 3114-3121.

11. Langley RE, Carmichael J, Jones AL, Cameron DA, Qian W, Uscinska B, Howell A, Parmar M. Phase III trial of epirubicin plus paclitaxel compared with epirubicin plus cyclophosphamide as first-line chemotherapy for metastatic breast cancer: United Kingdom National Cancer Research Institute trial AB01. J Clin Oncol 2005;23:8322-8330.

12. Nabholtz JM, Falkson C, Campos D, Szanto J, Martin M, Chan S, Pienkowski T, Zaluski J, Pinter T, Krzakowski M, Vorobiof D, Leonard R, Kennedy I, Azli N, Murawsky M, Riva A, Pouillart P; TAX 306 Study Group. Docetaxel and doxorubicin compared with doxorubicin and cyclophosphamide as firstline chemotherapy for metastatic breast cancer: results of a randomized, multicenter, phase III trial. J Clin Oncol 2003;21:968-975.

13. Ueno NT, Rizzo JD, Demirer T, Cheng YC, Hegenbart U, Zhang MJ, Bregni M, Carella A, Blaise D, Bashey A, Bitran JD, Bolwell BJ, Elfenbein GJ, Fields KK, Freytes CO, Gale RP, Lazarus HM, Champlin RE, Stiff PJ, Niederwieser D. Allogeneic hematopoietic cell transplantation for metastatic breast cancer. Bone Marrow Transplant. 2008;41:537-545.

14. Demirer T, Barkholt L, Blaise D, Pedrazzoli P, Aglietta M, Carella AM, Bay JO, Arpaci F, Rosti G, Gurman G, Niederwieser D, Bregni M; EBMT Solid Tumors Working Party. Transplantation of allogeneic hematopoietic stem cells: an emerging treatment modality for solid tumors. Nature clinical practice. Oncology 2008;5:256-267. 
15. Citron ML, Berry DA, Cirrincione $C$ et al. Randomized trial of dose-dense versus conventionally scheduled and sequential versus concurrent combination chemotherapy as postoperative adjuvant treatment of node-positive primary breast cancer: first report of Intergroup Trial C9741/Cancer and Leukemia Group B Trial 9741. J Clin Oncol 2003; 21: 1431-1439

16. Seidman AD, Berry D, Cirrincione $C$, et al. Randomized phase III trial of weekly compared with every-3weeks paclitaxel for metastatic breast cancer, with trastuzumab for all HER-2 overexpressors and random assignment to trastuzumab or not in HER-2 nonoverexpressors: final results of Cancer and Leukemia Group B protocol 9840. J Clin Oncol 2008; 26: 1642-1649.

17. Sparano JA, Wang M, Martino S, et al. Weekly paclitaxel in the adjuvant treatment of breast cancer. $\mathrm{N}$ Engl J Med 2008; 358: 1663-1671.

18. Farquhar CM, Marjoribanks J, Lethaby A, Basser R. High dose chemotherapy for poor prognosis breast cancer: a systematic review and meta-analysis. Cancer Treat Rev. 2007;33:325-337.

19. Mauri D, Polyzos NP, Salanti G, Pavlidis N, loannidis JP. Multiple-treatments meta-analysis of chemotherapy and targeted therapies in advanced breast cancer. J Natl Cancer Inst 2008;100: 1780-1791.

20. De Laurentiis M, Cancello G, D'Agostino D, Giuliano M, Giordano A, Montagna E, Lauria R, Forestieri V, Esposito A, Silvestro L, Pennacchio R, Criscitiello C, Montanino A, Limite G, Bianco AR, De Placido S. Taxane-based combinations as adjuvant chemotherapy of early breast cancer: a meta-analysis of randomized trials. J Clin Oncol. 2008;26:44-53.

21. Slamon DJ, Leyland-Jones B, Shak S, Fuchs H, Paton V, Bajamonde A, Fleming T, Eiermann W, Wolter J, Pegram M, Baselga J, Norton L. Use of chemotherapy plus a monoclonal antibody against HER2 for metastatic breast cancer than overexpresses HER2. N Engl J Med 2001;344:783-792. 

Samenvatting, conclusies en toekomstige ontwikkelingen 



\section{Samenvatting, conclusies en toekomstige ontwikkelingen}

In de westerse wereld is het mammacarcinoom de meest frequent voorkomende maligniteit bij vrouwen. Het is tevens de meest frequent voorkomende doodsoorzaak aan kanker en daarbij de meest frequente doodsoorzaak bij vrouwen tussen het $45^{\text {ste }}$ en $55^{\text {ste }}$ levensjaar. Bij de vroege stadia en bij het lokaal gevorderd stadium borstkanker bestaat de in opzet curatieve behandeling uit locoregionale therapie (chirurgie, al dan niet in combinatie met radiotherapie) en eventueel adjuvante systemische therapie. In die situaties, waarbij de ziekte zich verder heeft uitgebreid dan de locoregionale lymfklieren, spreekt men van op afstand uitgezaaide ziekte en resteren in principe slechts palliatieve opties. Alhoewel het overgrote deel van de patiënten met uitgezaaide ziekte initieel met regressie of stabilisatie zal reageren op de diverse combinatie chemotherapieschema's, zal er meestal binnen een jaar progressie optreden en bedraagt de mediane totale overleving na start van palliatieve behandeling gemiddeld twee tot drie jaren.

Dosis intensificatie van chemotherapie heeft tot doel de hoeveelheid toegediende chemotherapie per tijdseenheid te verhogen om een zo optimaal mogelijk antitumor effect te bereiken.

De dosis intensiteit, de dosis per kuur en de cumulatieve dosis zijn allen belangrijk, maar kunnen een verschillend antitumor effect hebben. Volgens Goldie en Coldman leidt een hoge dosisintensiteit tot een snelle en effectieve opruiming van gevoelige tumorcellen, waarbij een hogere dosis per kuur het risico op het ontwikkelen van chemotherapie resistente tumorcellen verlaagt. Norton e.a. lieten zien dat het groeibeloop van borstkanker overeenkomt met een Gompertze curve. In dit model wordt verondersteld dat patiënten met een uitgezaaide borstkanker, en dus een grote tumorlast, de fractie delende cellen laag is, en hierdoor de hoeveelheid gedode cellen per kuur beperkt is. Intervalverkorting tussen de kuren (densificatie) zou derhalve een mogelijkheid bieden om deze cytokinetische resistentie van de tumor te beïnvloeden.

Chemotherapie dosisintensificatie is echter slechts beperkt mogelijk vanwege bijwerkingen als diepe en langdurige beenmergonderdrukking, met het risico van koorts en infecties. Hematopoietische groeifactoren, en speciaal Granulocyt Koloniestimulerende Factor (G-CSF), biedt een mogelijkheid deze bijwerking te overbruggen. De toevoeging van G-CSF aan de chemotherapie vermindert niet alleen het optreden van neutropene koorts, maar ondersteunt ook de mogelijkheid tot verhoging van de dosisintensiteit van cytostatica toediening.

Dit kan langs twee wegen worden bereikt:

1. Standaard doseringen van cytostatica, waarbij het interval tussen de kuren wordt verkort (densificatie).

2. Standaard kuurinterval (veelal 3 weken), waarbij de dosering van cytostatica per kuur wordt verhoogd (dosis-escalatie). 
Beide benaderingen resulteren in een hogere dosisintensiteit, maar het biologisch effect en de klinische relevantie kunnen verschillen. Dit werd ook beschreven door Henderson e.a. in zijn overzichtsartikel over het dosisintensiteit fenomeen in borstkanker. De relatieve voordelen van de ene versus de andere benaderingswijze van dosisintensificatie is niet systematisch onderzocht.

Een anthracycline niet-taxaanbevattend chemotherapieschema als eerste lijn behandeling in gemetastaseerde borstkanker geeft een $30 \%$ tot $50 \%$ responskans, met een $5 \%$ tot $10 \%$ complete responskans en een mediane progressievrije overleving van vier tot acht maanden. Epirubicine is een anthracycline en een synthetische analoog van doxorubicine. Het heeft een gelijkwaardig antitumor effect maar wellicht een gunstiger toxiciteitprofiel in vergelijking met doxorubicine, waarbij met name minder cardiotoxiciteit.

In Hoofdstuk 2 worden de resultaten van een vergelijkende studie van dosis escalatie versus densificatie, om de maximale dosisintensiteit te verkrijgen van epirubicin en cyclofosfamide ondersteunt met G-CSF, beschreven. De tweede doelstelling was inzicht te verkrijgen in de veiligheidsaspecten van deze geïntensiveerde behandelingen.

In deze studie werden 49 patiënten met gemetastaseerd borstkanker behandeld met dagelijkse G-CSF injecties en oftewel oplopende doseringen van epirubicine en cyclofosfamide met gelijkblijvende kuurinterval (arm 1, dosis-escalatie), of steeds kortere kuurintervallen met gelijkblijvende doseringen van epirubicine en cyclofosfamide (arm 2, densificatie). Per kuurinterval/dosis, werd een cohort van minimaal 6 patiënten bestudeerd. Er werd overgegaan naar een meer geïntensiveerde kuurinterval/dosis indien minder dan $50 \%$ van de patiënten geconfronteerd werd met een dosislimiterende toxiciteit gedurende de eerste 3 kuren.

In arm 1, bleek epirubicine/cyclofosfamide $140 / 800 \mathrm{mg} / \mathrm{m}^{2}$ in een 3 wekelijkse cyclus te zwaar. Vervolgens werd epirubicine/cyclofosfamide $120 / 700 \mathrm{mg} / \mathrm{m}^{2}$ onderzocht. Hierop kregen 2 van de 10 patiënten een dosislimiterende toxiciteit. In beide gevallen betrof het neutropene koorts. In arm 2 werd epirubicine/cyclofosfamide 75/500 mg/m² veilig toegediend in een 14 en een 12 daags kuurinterval. In het 10 daagse interval konden 8 van de 12 patiënten de eerste 3 kuren ondergaan zonder ernstige toxiciteit. In het 8 daags interval werden 7 van de 8 patiënten geconfronteerd met een dosislimiterende toxiciteit. Onvolledig herstel van de witte bloedcellen, en in mindere mate slijmvliesirritatie, waren dosislimiterend. In $21 \%$ van de patiënten behandeld in een korter kuurinterval werd een klinisch asymptomatische cardio-toxiciteit geconstateerd, hetgeen volledig herstelde bij langere opvolging.

In combinatie met G-CSF, was epirubicine/cyclofosfamide $120 / 700 \mathrm{mg} / \mathrm{m}^{2}$ in een 3 wekelijkse cyclus haalbaar, met een geprojecteerde dosisintensiteit van respectievelijk $40 / 233 \mathrm{mg} / \mathrm{m}^{2} /$ week. Epirubicin/cyclofosfamide $75 / 500 \mathrm{mg} / \mathrm{m}^{2}$ kon veilig iedere 10 
dagen toegediend worden, hetgeen een hogere dosisintensiteit mogelijk maakte van respectievelijk 52,5/350 $\mathrm{mg} / \mathrm{m}^{2} /$ week.

Concluderend blijkt met toevoeging van G-CSF verkorting van het kuurinterval bij gelijkblijvende dosering een effectievere aanpak van dosisintensificatie dan dosisescalatie.

Naast anthracyclines, behoren de taxanen tot de meest actieve cytostatica bij de behandeling van gemetastaseerd borstkanker. Paclitaxel is zeer actief en vertoont geen kruisresistentie met andere frequent gebruikte cytostatica bij de behandeling van borstkanker. De combinatie van paclitaxel en doxorubicine liet in klinische fase I en II studies veelbelovende responspercentages zien van $83 \%$ tot $95 \%$. De superioriteit van deze anthracycline-taxaan combinatie werd vervolgens bevestigd in vijf gerandomiseerde fase III studies, met responspercentages van $55 \%$ tot $68 \%$, en een beperkte winst in de progressievrije overleving. Twee studies lieten een significante verbetering zien in de totale overleving, echter ten koste van een toename in therapie gerelateerde toxiciteit, hoofdzakelijk neutropene koorts, infecties en cardiotoxiciteit.

Hoofdstuk 3 beschrijft het onderzoek naar de maximale dosisintensiteit van de epirubicin/paclitaxel combinatie middels intervalverkorting bij patiënten met gemetastaseerde borstkanker. Het doel van het onderzoek was de bepaling van het kortst haalbare chemotherapie-interval en de bepaling van het veiligheidsprofiel van deze benaderingswijze.

Zesendertig patiënten met gemetastaseerde borstkanker werden in een multicenter fase $\mathrm{I} / \mathrm{II}$ studie onderzocht. De behandeling bestond uit epirubicine $75 \mathrm{mg} / \mathrm{m}^{2}$ gevolgd door paclitaxel $135 \mathrm{mg} / \mathrm{m}^{2}$ (3 uur infusie) in combinatie met G-CSF (5 $\mu \mathrm{gr} / \mathrm{kg}$ ). Minimaal 6 patiënten werden behandeld in ieder cohort en evaluatie vond plaats over de eerste 3 kuren. Er werd gestart met een 14 daags chemotherapie interval en in opeenvolgende cohorten kon het interval verkort worden tot 10 dagen.

Het 8 daagse interval was niet haalbaar, met name als gevolg van een incompleet herstel van de witte bloedcellen op de dag van de geplande volgende kuur. In het cohort van het 10 daagse interval kon de dosis van de paclitaxel worden verhoogd tot $175 \mathrm{mg} / \mathrm{m}^{2}$. De therapie gerelateerde toxiciteit was relatief mild. Negen van 36 patiënten ontwikkelden een dosis limiterende toxiciteit gedurende de eerste 3 kuren. Initieel waren dit incompleet hematologisch herstel op de dag van de geplande volgende kuur in vijf, neutropene koorts in één, en niet-hematologische toxiciteit in de resterende drie patiënten. Tijdens de eerste drie kuren waren er geen aanwijzingen voor cumulatieve beenmergonderdrukking. Na drie korte intervalkuren was er reeds sprake van een responspercentage van $53 \%$.

Concluderend, met de toevoeging van G-CSF lijkt intervalverkorting van chemotherapiekuren een haalbare aanpak van dosisintensificatie, waarbij een dosis- 
intensiteit van $52 \mathrm{mg} / \mathrm{m}^{2} /$ week voor epirubicine en van $122 \mathrm{mg} / \mathrm{m}^{2} /$ week voor paclitaxel mogelijk was.

De effectiviteit en klinische relevantie van deze benadering zal onderzocht moeten worden in een fase II onderzoek.

In Hoofdstuk 4 worden de twee benaderingen van dosisintensificatie, dosis-escalatie en densificatie, voor de combinatie van epirubicine en paclitaxel ondersteund met G-CSF onderzocht.

Deze multicenter gerandomiseerde fase II studie onderzocht de volgende twee schema's: epirubicine $110 \mathrm{mg} / \mathrm{m}^{2}$ gecombineerd met paclitaxel $200 \mathrm{mg} / \mathrm{m}^{2}$ in een 3 wekelijkse cyclus (dosis-escalatie) en epirubicine $75 \mathrm{mg} / \mathrm{m}^{2}$ gecombineerd met paclitaxel $175 \mathrm{mg} / \mathrm{m}^{2}$ in een 10 daagse cyclus (densificatie). Patiënten met gemetastaseerde borstkanker en zonder eerdere palliatieve chemotherapie ondergingen 6 kuren chemotherapie.

In totaal waren er 106 patiënten evalueerbaar voor toxiciteit en 101 patiënten voor tumorrespons. Graad $\geq 3$ bijwerkingen trad in 39\% van de dosis-escalatie patiënten op en in $29 \%$ van de densificatie patiënten, hoofdzakelijk bestaande uit neutropene koorts, bloedplaatjes onderdrukking en perifere neuropathie. Asymptomatische hartspiertoxiciteit werd frequenter in de dosis-escalatie arm (16\% vs $8 \%)$ gediagnosticeerd. Een mogelijke verklaring is de hogere cumulatieve dosering van epirubicine in de dosis-escalatie arm, naast de farmacokinetische interactie tussen epirubicine en paclitaxel. The mediaan toegediende cumulatieve doseringen van epirubicine/paclitaxel waren $656 / 1194 \mathrm{mg} / \mathrm{m}^{2}$ en $448 / 1045 \mathrm{mg} / \mathrm{m}^{2}$, de totale behandeltijd 126 en 61 dagen. De toegediende dosisintensiteit van epirubicine/paclitaxel was $36 / 67 \mathrm{mg} / \mathrm{m}^{2} /$ week en $51 / 120 \mathrm{mg} / \mathrm{m}^{2} /$ week, voor respectievelijk de dosis-escalatie arm en de densificatie arm. Beide therapieschema's waren zeer effectief met een totaal tumor responspercentage van $70 \%$ of meer. Na 3 kuren chemotherapie bedroeg deze $51 \%$ in de densificatie arm (na 1 maand behandeling) en $55 \%$ in the dosis-escalatie arm (na 2 maanden behandeling). Ondanks halvering van de behandelingsduur in de densificatie arm, en een lagere cumulatieve dosering van de cytostatica lijkt de progressievrije overleving (respectievelijk 6 en 7 maanden) voor de beide behandelarmen vergelijkbaar. In de densificatie arm bedroeg het therapievrije interval 5 maanden, terwijl deze in de dosis-escalatie arm maar 2 maanden was.

Door de kortere totale behandelingstijd en minder bijwerkingen lijkt de densificatie benadering het voorkeurschema van dosisintensificatie te zijn.

Wij denken dat verder onderzoek naar het concept van densificatie van chemotherapie in de behandeling van borstkanker aangewezen is.

Adjuvante systemische therapie in bepaalde groepen patiënten met een vroeg stadium borstkanker, leidt tot een beperkte maar consistente verbetering in de lange termijn ziektevrije overleving en totale overleving. Pogingen om de dosis van de 
cytostatica nog verder te verhogen worden ondanks ondersteuning met hematopoietische groeifactoren, met name belemmerd door langdurige diepe beenmergonderdrukking. Hoge dosis chemotherapie, gevolgd door autologe stamcel transplantatie biedt de mogelijkheid deze complicatie deels te omzeilen. Of deze behandeling leidt tot een betere ziektevrije en totale overleving was indertijd onduidelijk.

In Hoofdstuk 5 wordt het concept van hoge dosis chemotherapie met autologe stamcel ondersteuning als consolidatie therapie na standaard adjuvante chemotherapie in borstkanker patiënten met 7 of meer aangedane axillaire lymfklieren onderzocht. In de periode november 1991 tot en met oktober 1995 ondergingen 19 patiënten na chirurgische behandeling 4 standaardkuren adjuvante chemotherapie gevolgd door hoge dosis chemotherapie (busulfan en cyclofosfamide) en autologe stamcel transplantatie.

De mediane leeftijd was 41 jaar, het mediane aantal aangedane axillaire lymfklieren was 11 (range 7-29) en negen patiënten hadden een oestrogeenreceptor positieve tumor. Na een relatief korte mediane follow-up van 45 maanden, waren er twee patiënten overleden aan de complicaties van de behandeling en was er bij negen patiënten een terugval van de ziekte opgetreden. De mediane ziektevrije overleving was 16 maanden en de mediane totale overleving bedroeg 27 maanden.

Een recente update met een mediane follow-up van meer dan 16 jaar, laat zien dat 12 van de 19 patiënten een recidief hebben ontwikkeld en uiteindelijk aan borstkanker zijn overleden, resulterend in een ziektevrije overleving van $21 \%$ en totale overleving van $26 \%$.

Concluderend, is hoge dosis chemotherapie met autologe stamcel transplantatie in hoge risico borstkanker patiënten een toxische behandeling en laat voor de totale groep geen overlevingswinst zien.

Hoofdstuk 6 beschrijft de resultaten van een fase II studie van HLA-matched allogene stamcel transplantatie na een lagere dosering chemotherapie conditionering (de zogenaamde reduced-intensity conditionering (RIC)) met fludarabine/cyclofosfamide in 15 patiënten met uitgezaaide borstkanker. Deze single center onderzoek had als doel de haalbaarheid, veiligheid en effectiviteit van deze behandelmethode te evalueren. Het pretransplantatie conditionering schema bestond uit fludarabine $\left(25 \mathrm{mg} / \mathrm{m}^{2}\right.$ dag -5 tot en met -1$)$ en cyclofosfamide $(60 \mathrm{mg} / \mathrm{kg}$ dag -2 en -1$)$. Perifere bloed stamcellen werden verkregen van een HLA-matched broer of zus.

Therapie gerelateerde mortaliteit trad op bij 2 patiënten (13\%). De mediane progressievrije overleving en de totale overleving bedroegen respectievelijk 144 dagen (43-509 dagen) en 303 dagen (122-1376 dagen). De één jaar progressievrije overleving was $20 \%$, en de één jaar en twee jaar totale overleving bedroeg respectievelijk $40 \%$ en $20 \%$. Een objectieve tumorrespons werd niet geobserveerd. 
Dus, alhoewel 'reduced-intensity conditionering' stamcel transplantatie haalbaar is, lijkt de effectiviteit in deze patiënten categorie beperkt. Nieuwe klinische onderzoeken zijn noodzakelijk om meer inzicht te verkrijgen in de mechanismen van het antitumor effect in borstkanker.

\section{Samenvattend}

In uitgezaaide borstkanker hebben we laten zien dat de twee benaderingen van dosisintensificatie, densificatie en dosis escalatie, van taxaan-bevattende en niet taxaan-bevattende combinatie chemotherapie haalbaar is. Densificatie vergeleken met dosis escalatie leidt echter tot een hogere chemotherapie dosisintensiteit en een lagere cumulatieve dosis. Desondanks lijkt er sprake te zijn van een hogere effectiviteit en minder bijwerkingen bij het densificatie schema. Ook anderen hebben de superioriteit laten zien van een densificatie schema boven een standaard chemotherapie schema. Echter als gevolg van de beperkt beschikbare data, is dosis densificatie (nog) geen standaard behandeling . De enige uitzondering hierop vormt echter het cytostaticum paclitaxel. Zowel in de adjuvante als uitgezaaide setting van borstkanker, blijkt de wekelijkse toediening superieur aan de 3-wekelijkse toediening, zowel in response percentage als overleving.

Bij borstkanker patiënten met een groot aantal positieve klieren lijkt hoge dosis chemotherapie met autologe beenmerg transplantatie als consolidatie na standaard adjuvante chemotherapie, geen overlevingswinst te bieden ten opzichte van conventionele adjuvante chemotherapie. Een meta-analyse van 13 gerandomiseerde studies liet evenmin winst zien van hoge dosis chemotherapie boven standaard adjuvante chemotherapie. In feite, lijkt de intensieve behandeling zelfs nadelig, met een toename aan sterfgevallen als gevolg van de behandeling.

Een alternatieve benadering voor hoge dosis chemotherapie met autologe beenmergtransplantatie is HLA-matched allogene stamcel transplantatie na een 'reduced intensity conditionering' schema. Deze techniek blijkt haalbaar te zijn echter vooralsnog lijkt de effectiviteit beperkt te zijn.

\section{Huidige standaard behandeling}

Een recente meta-analyse van de overlevingsresultaten van 128 gerandomiseerde studies laat een duidelijke absolute overlevingswinst zien voor toepassing van anthracyclines, taxanen, nieuwe niet-taxanen cytostatica zoals capecitabine en gemcitabine, zowel als monotherapie en als combinatie chemotherapie. De geschatte winst in levensverwachting met deze nieuwe middelen varieert van 4 tot 12 maanden. Recente trials hebben laten zien dat in de adjuvante setting combinaties van anthracyclines en taxanen superieur zijn ten opzichte van de oudere chemotherapieschema's. 


\section{Toekomstige ontwikkelingen}

In het laatste decennium hebben zich belangrijke ontwikkelingen in de systeembehandeling van borstkanker voorgedaan. De introductie van de derde generatie aromataseremmers hebben het terrein van de endocriene behandeling drastisch veranderd.

Nog belangrijker was de ontdekking van de receptoren van de HER-familie, waarbij de HER2 receptor momenteel een zeer belangrijke doelwit is in de behandeling van borstkanker. Bij ongeveer $20 \%$ van de borstkanker patiënten is er sprake van een amplificatie van het proto-oncogeen HER2. Amplificatie/overexpressie van HER2 voorspelt een respons op behandelingen gericht op de HER2, zoals de gehumaniseerde monoklonale antilichaam trastuzumab en de klein moleculaire tyrosine kinase remmer lapatinib.

Andere nieuwe ontwikkelingen op het terrein van doelgerichte antitumor therapie betreft de Vascular Endothelial Growth Factor (VEGF) gerichte behandelingen middels monoklonale antilichamen of tyrosine kinase remmers en de Poly ADP Ribose Polymerase (PARP) remmers, met name in de triple negatieve patiënten subgroep. In de nabije toekomst kan het ontrafelen van de moleculaire pathways mogelijk de selectie van borstkankerpatiënten die voor de klassieke cytostatica zoals de anthracyclinen en taxanen in aanmerking komen verbeteren. Als we straks inderdaad in staat zijn patiënten met een chemosensitieve tumor op basis van biologische kenmerken te herkennen, is het wellicht mogelijk door kleine aanpassingen in het chemotherapieschema de uitkomst te verbeteren. Samenvattend, kan toename in inzichten over de moleculaire pathways mogelijk een bijdrage leveren aan toekomstig onderzoek naar dosis densificatie van chemotherapie in een geselecteerde patiënten populatie. 

List of publications 



\section{List of publications}

\section{Artikelen}

1. Puylaert JBCM, Rutgers PH, Lalisang RI, de Vries BC, van der Werf SDJ, Dorr JPJ, Blok RAPR. A prospective study of ultrasonography in the diagnosis of appendicitis. N Engl J Med 1987;317:666-669.

2. Puylaert JBCM, Rutgers PH, Lalisang RI, de Vries BC, van der Werf SDJ, Dorr JPJ, Blok RAPR. A prospective study of ultrasonography in the diagnosis of appendicitis. The Year Book of Medicine 1988 (Rogers DE, Des Prez RM, Cline MJ, Braunwald E, Greenberger NJ, Wilson JD, Epstein FH, Malawista SE, eds) Year Book Medical Publishers, Inc. Chicago, London, Boca Raton: 1987:464-465, 1987.

3. Puylaert JBCM, Hoekstra F, de Vries BC, Rutgers PH, Lalisang RI, Ooms EC. Radiation appendicitis: Demonstration with graded compression US. Radiology 1987;164: 342.

4. Puylaert JBCM, Lalisang RI, van der Werf SDJ, Doornbos L. Campylobacter lleocolitis mimicking acute appendicitis: Differentation with graded-compression US. Radiology 1988;166:737-740.

5. Lalisang RI, Hillen HFP, Blijham GH. Dosisintensificatie bij het gemetastaseerd mammacarcinoom. Verslag refereersymposium, Efteling oktober 1994, uitgave van Pharmacia.

6. Lalisang R, Wils J, Nortier J, Burghouts J, Hupperets P, Erdkamp F, Blijham G. Dosis-intensificatie met Epirubicine/Cyclophosphamide + G-CSF bij het gemetastaseerd mammacarcinoom: een vergelijkende studie tussen intervalverkorting en dosis-escalatie. Integraal Kankercentrum Limburg Nieuwsbrief 1994;11:1.

7. van Oostenbrugge RJ, Freling G, Lodder J, Lalisang R, Twijnstra A. Fatal stroke due to paradoxical fat embolism. Cerebrovasc Dis 1996;6:313-314.

8. Lalisang RI, Wils JAMJ, Nortier J, Burghouts JThM, Hupperets PSGJ, Erdkamp FLG, Schouten HC, Blijham GH. A comparative study of dose escalation versus interval reduction to obtain dose intensification of epirubicin and cyclophosphamide with G-CSF in patients with advanced breast cancer. J. Clin. Oncol 1997;15:1367-1376.

9. Lalisang RI, Hupperets PSGJ, ten Haaft MA, Jansen RLH, Schouten HC. High-dose chemotherapy with autologous bone marrow support as consolidation after standard-dose adjuvant therapy in primary breast cancer patients with 7 or more involved axillary lymphnodes. Bone Marrow Transplantation 1998;21:243-247.

10. Rodenhuis S, de Wit R, Mulder PHM, Keizer HJ, Sleijfer DT, Lalisang RI, Bakker PJM, Mandjes I, Kooi M, de Vries EGE. A multi-center prospective phase II study of high-dose chemotherapy in germ-cell cancer patients realpsing from complete remission. Annals of Oncology 1999;10:1467-1473.

11. Lalisang RI, Voest EE, Wils JA, Nortier JW, Erdkamp FL, Hillen HF, Wals J, Schouten HC, Blijham GH. Dose-dense Epirubicin and Paclitaxel with G-CSF: a study of 
decreasing intervals in metastatic breast cancer. British Journal of Cancer 2000;82:1914-1919.

12. Lalisang RI. Dosis-intensificatie van Epirubicine en Taxol met G-CSF (Neupogen) ondersteuning in patiënten met uitgezaaide borstkanker: een gerandomiseerde fase II studie van dose-dense en dosisgeëscaleerde chemotherapie. (L98-02) NWD 2000

13. Peters FP, Lalisang RI, Fickers MM, Erdkamp FL, Wils JA, Houben SG, Wals J, Schouten HC.Treatment of elderly patients with intermediate- and high-grade non-Hodgkin's lymphoma: a retrospective population-based study. Annals of Hematology 2001;80:155-159.

14. Huugen D, Bos GM, Jansen M, Lalisang R, Jansen R, Wagstaff J, Schouten HC. Non-myeloablative allogeneic stem cell transplantation in patients with solid tumours and patients with a haematological malignancy. Netherlands Journal of Medicine2002;60:170-173.

15. Lalisang RI, Knibbeler-van Rossum C. Dosis-intensificatie van Epirubicine en Taxol met G-CSF (Neupogen) ondersteuning als eerstelijns behandeling in patiënten met uitgezaaide borstkanker: een gerandomiseerde fase II studie van dose-dense en dosisgeëscaleerde chemotherapie. (L98-02) Complete Respons 2002;1:1-2.

16. Green MD, Koebl H, Baselga J, Galid A, Guillem V, Gascon P, Siena S, Lalisang RI, Samonigg $\mathrm{H}$, Clemens MR, Zani V, Bashir S, Liang BC, Piccart MJ. Fixed-dose, single-administration SD/01 versus daily Filgrastim in Patients with High-risk Breast Cancer. Annals of Oncology 14:29-35, 2003

17. de Rijke JM, Schouten LJ, ten Velde GPM, Wanders SL, Bollen ECM, Lalisang RI, van Dijck JAAM, Kramer GWPM, van den Brandt PA. Influence of age, comorbidity and performance status on the choice of treatment of patients with non-small cell lung cancer. Results of a population-based study. Lung Cancer 2004;46:233-245.

18. Lalisang RI. Is er een rol voor chemotherapeutische onderhoudsbehandeling bij de primaire behandeling epitheliaal ovariumcarcinoom? Oncologie Actueel $2005 ; 7(1)$.

19. Fleskens AJHM, Lalisang RI, Bos GMJ, van Gelder M, Jansen RLH, Schouten HC. HLA-matched allo-SCT after reduced intensity conditioning with fludarabine/CY in patients with metastatic breast cancer. Bone Marrow Transplantation 2010;45:464-467.

20. J. van Loon, D. De Ruysscher, M. Janssen, M. Oellers, H. Aerts, M. Hochstenbag, A. Dingemans, R. Lalisang, B. Brans, B. Windhorst, G. van Dongen, H. Kolb, J. Zhang, P. Lambin PET imaging of hypoxia with the new tracer ${ }^{18} \mathrm{~F}-\mathrm{HX} 4$ : A phase 1 trial. Eur J Nucl Med. in press . 
21. Lalisang RI, Erdkamp FLG, Rodenburg CJ, Knibbeler-van Rossum CTAM, Nortier JWR, van Bochove A, Slee PHThJ, Voest EE, Wils JA, Wals J, Loosveld OJL, Smals AEM, Blijham GH, Tjan-Heijnen VCG, Schouten HC. Epirubicin and paclitaxel with G-CSF support in first line metastatic breast cancer: A randomized phase II study of dose-dense and dose-escalated chemotherapy. Submitted

22. Lalisang RI, Tjan-Heijnen VCG, Schouten HC. High-dose chemotherapy with autologous bone marrow support as consolidation after standard-dose adjuvant therapy in high-risk primary breast cancer patients: an update. Submitted.

\section{Abstracts in proceedings}

1. Lalisang RI, Blijham GH, Wagener DJTh, Wils JA, Neijt JP, van Oosterom AT, Kok TC. High dose Fluorouracil (FU) plus oral Leucovorin for the treatment of advanced colorectal cancer. The Netherlands Journal of Medicine 1990;37:A32.

2. Lalisang RI, Stals F, Schouten HC. Isolation of Herpes Simplex virus type 1 in patients with severe stomatitis after chemotherapy. The Netherlands Journal of Medicine 1993;42(6):A106.

3. Lalisang R, Wils J, Nortier J, Burghouts J, Hupperets P, Erdkamp F, Schouten H, Blijham $G$. A comparative study of dose escalation vs interval reduction to obtain dose intensification of epirubicin and cyclophosphamide with granulocyte colony-stimulating factor (Filgrastim) for patients with metastatic breast cancer. The Netherlands Journal of Medicine 1994;44:A56

4. Lalisang R, Wils J, Nortier J, Burghouts J, Hupperets P, Erdkamp F, Schouten H, Blijham G. A comparative study of dose escalation vs interval reduction to obtain dose intensification of epirubicin and cyclophosphamide with granulocyte colony-stimulating factor (Filgrastim) for patients with metastatic breast cancer. Proc Am Soc Clin Oncol 1994;13:A42

5. Lalisang R, Wils J, Nortier J, Erdkamp F, Wals J, Hillen H, Blijham G. Dose intensification of Epirubicin and Paclitaxel with G-CSF support in metastatic breast cancer. Seminars in Oncology. NCl-EORTC 1995

6. Lalisang R, Wils J, Nortier J, Erdkamp F, Wals J, Hillen H, Blijham G. Doseintensification of Epirubicin (E) and Paclitaxel (P) with G-CSF (Filgrastim) support in metastatic breast cancer (MBC). Proc Am Soc Clin Oncol 1996;15: 99 (A62)

7. Nortier J, Wils J, Erdkamp F, Lalisang R, Wals J, Hillen H, Blijham G. Dose Dense Epirubicin (E) and Paclitaxel (P) with G-CSF in metastatic breast cancer (MBC). Proceedings $7^{\text {th }}$ EORTC Breast Cancer Working Conference, Eur J Cancer 1996;32, Supplement 2:46

8. Peters FPJ, Lalisang RI, Erdkamp FLG, Bron H, Fickers M, Schouten HC. Treatment of intermediate and high-grade non-Hodgkin's lymphoma in elderly. The Netherlands Journal of Medicine 1997;50: A5 
9. Lalisang R, Nortier J, Wils J, Erdkamp F, Wals J, Hillen H, Blijham G. Dose dense epirubicin (E) and Paclitaxel (P) with G-CSF (Filgrastim) in metastatic breast cancer (MBC): a weekly schedule? Proc Am Soc Clin Oncol 1997;16: A178 (624)

10. Schouten $H$, Lalisang $R$, Hupperets $P$, ten Haaft $M$, Jansen R. High-dose chemotherapy (HDC) with autologous bone marrow support (ABMS) in primary breast cancer patients with seven or more involved axillary lymph nodes. Proc Am Soc Clin Oncol 1997;16:125a (442)

11. Wils J, Bron H, Erdkamp F, Vreeswijk J, v Geuns H, vd Putten H, v Rijswijk R, Werter $M$, Stoot J, Wals J, Lalisang R. Docetaxel $(T)$, epirubicin (E) and cisplatinum (P) with G-CSF (lenograstim) support in patients with advanced ovarian cancer. Proc Am Soc Clin Oncol 1997;16: 382a (1361)

12. Hupperets $P$, ten Haaft $M$, Lalisang $R$, Schouten $H$. High-dose chemotherapy with autologous haematopoietic progenitor cell support for metastatic breast cancer. The 15th Annual Symposium of the European Cancer Prevention Organization, Brugge, Belgium, June 26-28, 1997

13. Peters FPJ, Lalisang RI, Erdkamp FLG, Bron H, Fickers M, Wils J, Wals J, Schouten HC. Treatment of intermediate and high-grade non-Hodgkin's lymphoma in elderly. Eur J Int Med 1997;8:O29, 30.

14. Lalisang R, Wils J, Voest E, Nortier H, Hillen H, Schouten H, Blijham G. Dose escalation of epirubicin (E) and paclitaxel (P) with G-CSF (filgrastim) support in patients with metastatic breast cancer (MBC). Proc Am Soc Clin Oncology 1998; 17: $153 a$

15. Wils J, Lalisang R, Erdkamp F, Vreeswijk J, Wals J, van Geuns H, van de Putten H, Werter M, Stoot J, Schepers J, de Pree N, Degen J, Iding R, for the Gynecologic Oncology Group Limburg. Docetaxel (T), epirubicin (E) and cisplatinum (P) with GCSF (lenograstim) in patients with advanced ovarian cancer. Proc Am Soc Clin Oncol, 1998,17: 377a (1454)

16. Peters FPJ, Lalisang RI, Fickers MMF, Erdkamp FLG, Wils JAJM, Houben HGJ, Wals J, Schouten HC. Treatment of intermediate and high-grade non-Hodgkin's lymphoma in elderly. Proc Am Soc Clin Oncol, 1998; 17: 34a.

17. Rodenhuis S, de Wit R, Mulder PHM, Keizer HJ, Sleijfer DTh, Veenhof CHN, Lalisang RI, Kooi M, de Vries EGE. A prospective multi-center trial of repeated high-dose chemotherapy in relapsing germ cell cancer. Proc Am Soc Clin Oncol 1999; 18: 310a.

18. Green M, Koelbl H, Baselga J, Kubista E, Guillem V, Gascon P, Siena S, Lalisang R, Krippl P, Clemens M, Zani V, Bachir S, Renwick J, Bertrand C. Liang, M. Piccart. Fixed-dose, once-per-cycle pegfilgrastim is equivalent to daily filgrastim as prophylaxis against chemotherapy-induced neutropenia (CIN) in high-risk breast cancer patients American College of Clinical Pharmacy 2001 Annual Meeting, $167 a$ 
19. Knibbeler-van Rossum C, Erdkamp F, Rodenburg C, Voest E, Nortier J, van Bochove A, Slee P, Wils J, Loosveld O, Lalisang R. Dose Intensification of Epirubicin and Taxol with G-CSF Support for Patients with Metastatic Breast Cancer: A Randomised phase II study of Dose-dense and Dose-escalated Chemotherapy. Proc Am Soc Clin Oncol 2002;21: 2040a

20. Knibbeler-van Rossum C, Erdkamp F, Rodenburg C, Voest E, Nortier J, van Bochove A, Slee P, Wils J, Loosveld O, Lalisang R. Dose Intensification of Epirubicin and Taxol with G-CSF Support for Patients with Metastatic Breast Cancer: A Randomised phase II study of Dose-dense and Dose-escalated Chemotherapy. Proc Am Soc Clin Oncol 2003; 22: 2046a.

21. Lalisang R, Erdkamp F, Wils J, Vreeswijk J, Wals J, Stoot J, Groot Y, Smeets J, van Geuns H. A phase II study of docetaxel, epirubicin, and cisplatin with G-CSF (lenograstim) support in patients with advanced ovarian cancer. European Journal of Cancer 2003; Sup 1, 5, 2003, S54

22. Lutgens L, Vos $C$, Hermans $R$, van der Putten $H$, Lalisang R, Lambin P. Whole abdominal radiation: a curative treatment option in a subset of patients with epithelial ovarian carcinoma irresponsive to chemotherapy. ESTRO 2006

23. Reyners A, Smit WM, Schaapveld MS, Hoekman K, Erdkamp F, Lalisang R, Graaf $\mathrm{H}$, Wymenga MA, Polee M, Willemse PH. Adding the specific COX-2 inhibitor celecoxib to docetaxel plus carboplatin in first line for stage IC-IV epithelial ovarian cancer: A randomized phase II study. Proc Am Soc Clin Oncol 2009; 27: 15S: 5545

24. Amkreutz LCM, Lalisang RI, Stoot JEGM, Nolting WE, Bergmans M, Mertens HJMM. Early stage ovarian cancer: differences in surgical staging and treatment. Proc Eur Soc Gynaec Oncol 2009:109 

Dankwoord 



\section{Dankwoord}

$\mathrm{Na}$ vele jaren van onderzoek en nog diverse jaren voor het afronden hiervan is mijn proefschrift eindelijk een feit.

Velen ben ik dank verschuldigd voor hun bijdrage aan dit proefschrift.

Een zeer belangrijke bijdrage hebben de patiënten geleverd die deelgenomen hebben aan de diverse studies, waarvoor mijn dank.

Een aantal mensen wil ik bij naam noemen, zonder naar volledigheid te willen streven. Ik ga daarbij terug in de tijd.

Het was Prof. dr. G.H. Blijham (toenmalig hoofd van de werkgroep HematologieOncologie) die mij begeleidde bij de eerste schreden in de medische oncologie en het klinische onderzoek, en mij vervolgens stimuleerde onderzoek te gaan verrichten naar chemotherapie dosisintensificatie. Beste Geert, ondanks het feit dat je in 1992 Maastricht verruilde voor Utrecht en je meer ging richten op bestuurlijke activiteiten, bleef je nauw betrokken bij mijn onderzoek. Je kritische analyses en verrassende ideeën waren altijd zeer welkom. Het was voor mij een voorrecht om met jou te mogen samenwerken, waarvoor hartelijk dank.

Prof. dr. H.C. Schouten, was na 1992 de continue factor in de begeleiding en ondersteuning van de diverse studies. Beste Harry, het was jouw ingenieuze idee om het concept van stamceltransplantatie mee te nemen in mijn onderzoeken naar dosisintensificatie. In al de jaren heb je steeds achter mijn onderzoeken gestaan. Jij hebt mij ook wegwijs gemaakt in de beginselen van de maligne hematologie. Dank voor de jarenlange prettige samenwerking, steun en het vertrouwen.

Prof. dr. V.C.G. Tjan-Heijnen, hoofd van de onderafdeling Medische Oncologie sinds haar komst in september 2006, was vanaf onze "eerste kennismaking" ervan overtuigd dat het proefschrift binnen afzienbare tijd zou worden afgerond. Hartelijk dank Vivianne, het is mede dankzij jouw hulp, doelgerichtheid en vasthoudendheid dat mijn boekje nu klaar is.

De onderzoeken waren niet mogelijk geweest zonder de actieve participatie vanuit de diverse deelnemende ziekenhuizen door de collega's: dr. F.L.G. Erdkamp, dr. J.A.M.J. Wils, dr. C.J. Rodenburg, Prof. dr. J.W. Nortier (indertijd werkzaam in het Diaconessenhuis te Utrecht), Prof. dr. E.E. Voest, drs. J. Wals, drs. C.T.A.M. Knibbelervan Rossum (indertijd werkzaam in het St. Elisabeth ziekenhuis te Tiburg), drs. A. van Bochove, dr. J.Th.M. Burghouts, dr. P.H.Th.J. Slee, drs. O.J.L. Loosveld, dr. A.E.M. Smals, dr. R.L.H. Jansen, dr. P.S.G.J. Hupperets, dr. R. van Rijswijk, dr. G.M.J. Bos, dr. M. van Gelder en drs. M.A. ten Haaft. Met veel plezier en warme gevoelens denk ik terug aan de diverse studiebijeenkomsten ergens tussen Maastricht en Utrecht of 
tijdens het jaarlijkse ASCO congres in de Verenigde Staten. Dank voor jullie betrokkenheid en inzet.

Een speciaal woord van dank aan Prof. dr. J.W.R. Nortier, Prof. dr. E.E. Voest en Prof. dr. H.F.P. Hillen voor jullie bijdrage aan het mede ontwerpen van de dosisintensificatie studies.

De sponsors van de dosisintensificatie studies waren de firma's Amgen BV, Pharmacia \& Upjohn en Bristol-Myers Squibb BV. Pieter Oosthoek, Jan Smeets en Gerrit Verhagen, hartelijk dank voor jullie nimmer aflatende ondersteuning. "Mortons" is nu voor mij een vast programmaonderdeel van de jaarlijkse ASCO bezoeken geworden.

De datamanagers van de deelnemende ziekenhuizen en Integrale Kanker Centra's; A. Epping, M. Bongers, B. Hagemans, M. Jansen, H. Leurs, C. Erdkamp, I. van Beuningen, M. Waber, R. Goossens, A. Huldij en A. Kroen, dank voor het zorgvuldig en tijdig aanleveren van de CRF's.

De leden van de beoordelingscommissie, Prof.dr.M.F. von Meyenfeldt, Prof.dr. J.B. Vermorken, Prof.dr. R.F.P.M. Kruitwagen en Prof. dr. P. Lambin, ben ik zeer erkentelijk voor de beoordeling en goedkeuring van dit proefschrift.

Beste Tiny Wouters, dank voor de fraaie lay-out, de razendsnelle correcties en je fantastische opmerkingsgave voor foutjes in mijn proefschrift. Voor Fabiano Peltrera was het ontwerpen van de boekomslag een uitdaging waarin hij succesvol is geslaagd.

Lieve ouders, na 6 jaar in Indonesië te hebben verbleven, namen jullie in 1966 het moedige en wijze besluit, dat de toekomst van onze familie in Nederland zou liggen. Het was een flinke stap terug, jullie moesten opnieuw beginnen. Pa was de eerste arts in de familie en deelde met ons zijn liefde voor dit mooie vak. Drie kinderen zijn vervolgens in zijn voetsporen getreden. Pa was ook degene die de mogelijkheid van een promotieonderzoek bij mij aankaartte, iets wat in zijn eigen loopbaan niet tot de mogelijkheden behoorde. Beste $\mathrm{Pa}$ en $\mathrm{Ma}$, jullie hebben lang op deze dag moeten wachten, maar gelukkig kunnen jullie vandaag beiden in goede gezondheid aanwezig zijn.

Lieve Monique, al meer dan 30 jaar mijn steun en toeverlaat. Voor mij ben je naar het diepe zuiden komen afzakken. Je eigen carrière, het reilen en zeilen thuis en de kinderen, het werd allemaal vanzelfsprekend door jou georganiseerd en gecombineerd. Jij was de continue factor, en droeg zorg voor een warm en gezellig huis voor een ieder. Daarnaast zorgde je voor de noodzakelijke afwisseling tussen werk en ontspanning. Dank voor je onvoorwaardelijke steun, jij was de belangrijkste persoon achter mijn proefschrift. 
Tom, Roepie en Bibi, de zaterdagen zijn altijd heilig voor de familie en staat de sport centraal. Daarbuiten hebben jullie je vader veel achter de laptop gezien, bezig met zijn onderzoek of zijn werk. Nu heb ik meer tijd voor andere, wellicht belangrijkere zaken. 

Curriculum Vitae 



\section{Curriculum Vitae}

Roy Iqbal Lalisang werd geboren op 1 november 1958 te Leiden. Van 1960 tot 1966 verbleef hij in zijn vaderland, Indonesië. Hij bezocht het Bisschoppelijk College te Weert alwaar in 1976 het diploma Atheneum B werd behaald. Aansluitend werd de studie geneeskunde aan de Rijksuniversiteit te Leiden aangevangen, en werd in 1983 het artsexamen gehaald. Hij werkte vervolgens in de periode 1983 tot 1985 als artsassistent niet in opleiding op de afdeling Verloskunde en Eerste Hulp van het St. Jans Gasthuis te Weert. Aansluitend heeft hij gedurende 2 jaar (1985-1986) gewerkt als arts-assistent niet in opleiding op de afdeling Heelkunde van het Westeinde Ziekenhuis in Den Haag. In 1987 heeft hij gedurende 6 maanden geparticipeerd aan een tweetal onderzoeken (echografisch appendicitis onderzoek, afdeling radiologie, en onderzoek naar de postoperatieve resultaten van voorste kruisbandlaesies van de knie, afdeling Orthopedie) in het Westeinde Ziekenhuis in Den Haag. Vervolgens werkte hij als arts-assistent niet in opleiding op de afdeling Cardiopulmonale Chirurgie van het Catharina Ziekenhuis in Eindhoven. Juni 1988 begon hij als arts-assistent niet in opleiding op de afdeling Interne Geneeskunde van het Academisch Ziekenhuis Maastricht. In april 1989 werd aldaar gestart met de opleiding tot internist (opleiders Prof. dr. J.A. Flendrig †, Prof. dr. A.C. Nieuwenhuijzen Kruseman, Prof. dr. H.F.P. Hillen) met als specifiek aandachtsgebied Medische Oncologie (opleiders dr. H.C. Schouten, Prof. dr. H.F.P. Hillen) en afgerond op 1 april 1995. Binnen de werkgroep HematologieOncologie, was hij aanvankelijk werkzaam als Chef de Clinique. In 1997 werd hij benoemd als Algemeen Consulent Medische Oncologie bij het Integraal Kankercentrum Limburg, met als specifieke taken de Gynaecologische Oncologie en de Bronchustumoren. Sedert november 1998 heeft hij diverse taken verricht naast zijn continue parttime aanstelling als medisch oncoloog $(50 \%$ bij de werkgroep Hematologie-Oncologie [hoofd Prof. dr. J. Wagstaff, Prof. dr. H.C. Schouten] en sedert september 2006 onderafdeling Medische Oncologie [hoofd Prof. dr. V.C.G. TjanHeijnen]). Hij was werkzaam als medisch hoofd van de polikliniek Interne Geneeskunde tot 2001 en vervolgens tot medio 2005 werkzaam als medisch zorgmanager van de voormalige Behandel Zorg Eenheid V (BZE V). De functie van Directeur-bestuurder van de Resultaat Verantwoordelijke Eenheid (RVE) Medisch Interventie Centrum werd ingevuld tot eind 2007. Vanaf augustus 2008 is hij werkzaam bij de Maastro Clinic als "linking pin" met het azM. Sedert 2002 is hij tevens actief betrokken bij de introductie van de producttypering van oncologische zorgproducten, aanvankelijk voor de Nederlandsche Internisten Vereeniging en sinds 2009 voor de Nederlandse Vereniging voor Medische Oncologie. Binnen de onderafdeling Medische Oncologie heeft hij momenteel als specifieke aandachtsgebieden de gynaecologische oncologie, de hoofd-hals oncologie, het onderwijs aan studenten en de DBC registratie (Diagnose Behandel Combinatie).

Hij is gehuwd met Monique D'Agnolo. Samen hebben zij drie kinderen Tom (1991), Roepie (1993) en Bibi (1994). 
